\title{
Recent advances in ketene chemistry
}

\author{
Annette D. Allen and Thomas T. Tidwell* \\ Department of Chemistry, University of Toronto, Toronto, Ontario, Canada M5S $3 \mathrm{H6}$
}

Email: ttidwell@chem.utoronto.ca

Dedicated to the memory of Melvin S. Newman, a pioneer in ketene chemistry

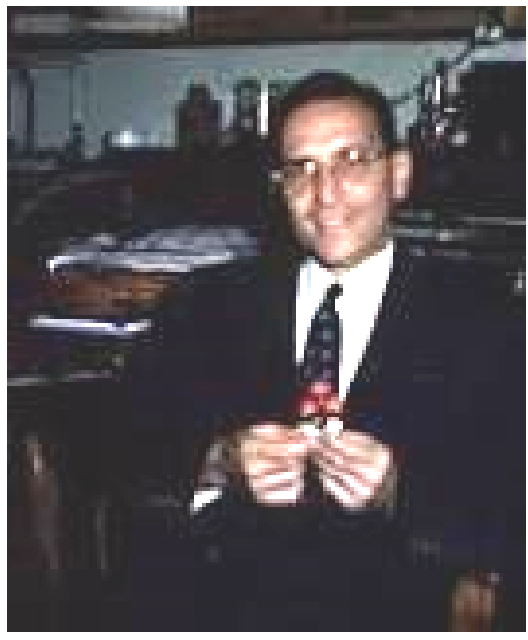

Melvin Newman (1908-1999)

DOI: https://doi.org/10.24820/ark.5550190.p009.634

\begin{abstract}
Recent advances in ketene chemistry are reviewed, including synthetic, mechanistic, and computational studies. Topics include ketene structure determination by experimental and theoretical methods, computational studies of bonding in ketenes, spectroscopic properties of ketenes, preparation and formation of ketenes including photochemical and thermal methods, the discovery and observation of ketenes in space, and ketene reactions. The last category includes decarbonylation, cycloadditions with carbon-carbon, carbon-nitrogen, and carbon-oxygen multiple bonds, addition of oxygen, nitrogen, and carbon nucleophiles, and electrophilic additions.
\end{abstract}

Keywords: Ketenes, cycloadditions, reaction mechanisms, computations 


\section{Table of Contents}

1. Introduction

2. Structure, Bonding, and Spectroscopy

3. Preparation and Formation of Ketenes

3.1 Ketenes by oxygenation reactions

3.2 Ketenes by ring opening of cyclobutenones

3.3 Ketenes from diazoketones

3.4 Ketenes by other photolytic, thermolytic, and mass spectral methods

3.5 Ketenes from carbonylation processes

3.6 Ketenes from carboxylic acids and their derivatives

3.7 Ketenes from dioxinones and ethynyl ethers

3.8 Ketenes by other methods

4. Cycloaddition Reactions of Ketenes

4.1 Ketene dimers, preparations and applications

4.2 [2+2] Cycloaddition reactions with carbon-carbon double and triple bonds

4.3 [2+2] Cycloaddition reactions with carbon-oxygen bonds

$4.4[2+2]$ Cycloaddition reactions with carbon-nitrogen bonds

4.5 [2+2+2] Cycloadditions

4.6 [3+2] Cycloadditions involving ketenes

4.7 [4+2] and [3+3] Cycloadditions and cyclizations

5. Nucleophilic Additions to Ketenes

5.1 Hydration and addition of other oxygen nucleophiles

5.2 Addition of nitrogen nucleophiles

5.3 Addition of carbon nucleophiles

6. Electrophilic Additions to Ketenes

7. Conclusions

8. Acknowledgements

9. References

\section{Introduction}

The chemistry of ketenes has long been of fascination to the authors, inspired by a publication in 1960 from the laboratory of Melvin Newman at The Ohio State University reporting the preparation of di-tert-butylketene (1), which is exceptional for its indefinite stability as a neat liquid at room temperature. ${ }^{1}$ Other alkylketenes are typically prone to dimerization and are sensitive to moisture and air, but the reactivity of $\mathbf{1}$ in aqueous solution could be measured (Scheme 1), ${ }^{2}$ with a rate constant less that that of mono-tert-butylketene by a factor of $9 \times 10^{4}$, a result attributed to the steric protection from in-plane attack of water at the carbonyl carbon. ${ }^{2}$ 


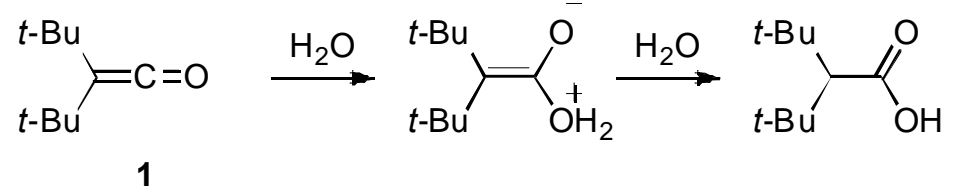

Scheme 1. Hydration of di-tert-butylketene.

Ketene chemistry remains a very active area of research worldwide, involving both synthetic and mechanistic studies, and has been extensively reviewed. ${ }^{3-15}$ This review describes the most recent work in the area, which is rich in further opportunities. The organization of this review includes separate headings on ketene preparation and on ketene reactions, but since ketenes are usually short-lived intermediates ketene formation and reactivity are usually inextricably mixed, and examples of one almost invariably contain the other.

\section{Structure, Bonding, and Spectroscopy}

The structure and excited state of the parent ketene (2) have been calculated by the SCF CI method and used to interpret the excited state of the molecule. ${ }^{16}$ Electron scattering by ketene has been studied by computational methods using the $R$-matrix method for energies ranging from 0 to $10 \mathrm{eV},{ }^{17}$ and the calculated vertical excitation energies of the first two excited states are in good agreement with experimental results. The electron scattering calculations predict two $\pi^{*}$ shape resonant states, one core-excited shape resonant state and one Feshbach resonant state.

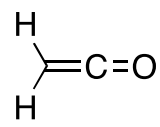

2

Computations of the $\tilde{\mathrm{X}}^{2} \mathrm{~B}_{1} \leftarrow \tilde{\mathrm{X}}^{1} \mathrm{~A}_{1}$ photoelectron spectra of ketene (Scheme 2) and of dideuteroketene give excellent agreement with available experimental data, and the calculated structure for the ketene radical cation is shown in Figure $1 .^{18}$

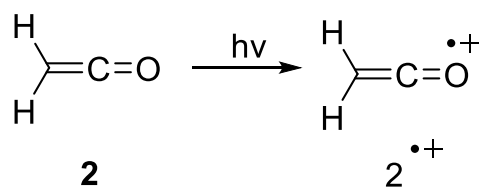

Scheme 2. Photoionization of ketene. 


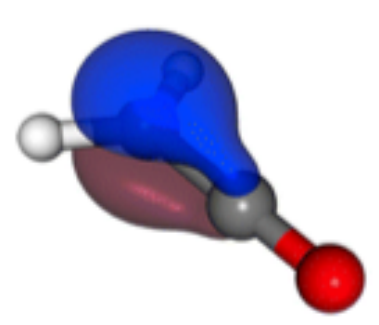

Figure 1. Singly occupied molecular orbital of the $\tilde{\mathrm{X}}^{2} \mathrm{~B}_{1}$ ketene radical cation (Reprinted with permission of the publisher ${ }^{18}$ ).

Modeling of the ethanol/oxygen flame was interpreted as showing the presence of butatrienone (3) at $8.56 \mathrm{eV}$, and ethynylketene (4) at $8.94 \mathrm{eV} .{ }^{19}$ Ketene $3^{19,20}$ has been reported experimentally, ${ }^{21}$ while $\mathbf{4}$ may have been detected, ${ }^{19}$ and substituted derivatives of $\mathbf{4}$ are known. ${ }^{22}$ The formation of $\mathbf{4}$ by the dehydration of 3-butynoic acid has also been studied computationally, ${ }^{23}$ as has the structure of isomer $\mathbf{5} .^{20,24}$

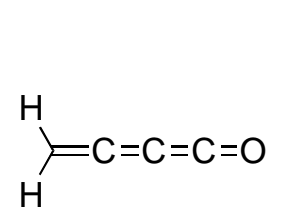

3

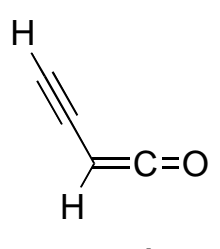

4

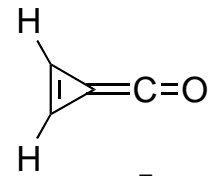

5

\section{Preparation and Formation of Ketenes}

Recent studies as described in this section reveal novel processes in which ketenes may be formed, and these add to the more traditional methods known previously.

\subsection{Ketenes by oxygenation reactions}

The conversion of ethylene to ketene by reaction with ground state oxygen atoms $\mathrm{O}\left({ }^{3} \mathrm{P}\right)$ has been studied by computational and experimental methods using a crossed molecular beam apparatus with universal soft electron ionization mass spectrometric detection, which indicate almost equal contributions from the triplet and singlet surfaces to the reaction (Scheme 3). ${ }^{25}$ The effects of added ethanol on ketene formation in ethylene flames have also been studied. ${ }^{26}$ 


$$
\begin{gathered}
\mathrm{O}\left({ }^{3} \mathrm{P}\right)+\mathrm{H}_{2} \mathrm{C}=\mathrm{CH}_{2} \longrightarrow{ }_{\mathrm{H}}=\mathrm{C}=\mathrm{O}+\mathrm{H}_{2} \\
\Delta H^{o}=-85.1^{a}(-84.2)^{b} \mathrm{kcal} / \mathrm{mol}
\end{gathered}
$$

( ${ }^{a}$ quantum chemical, ${ }^{b}$ experimental)

Scheme 3. Ketene formation from ground-state oxygen atom reaction with ethylene.

The formation of ketenes from alkynes occurs in particulate methane monooxygenase (pMMO) in Methylococcus capsulatus (Bath), which deactivates the transmembrane PmoC subunit by acetylation, as demonstrated using high-resolution MALDI-TOF mass spectrometry and computational simulation. ${ }^{27}$ Docking of methylketene (6), derived from methylacetylene, forms an adduct of the transmembrane PmoC subunit 7 (Scheme 4), as illustrated in Figure 2. ${ }^{27}$
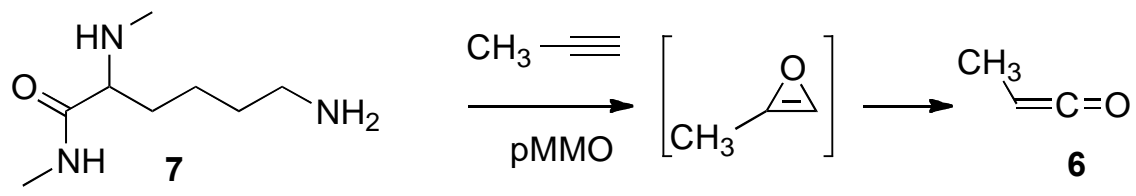<smiles>CCC(=O)NCCCCC(NC)C(=O)NC</smiles>

Scheme 4. Methylketene formation from propyne by methane monooxygenase, with transmembrane PmoC acylation.

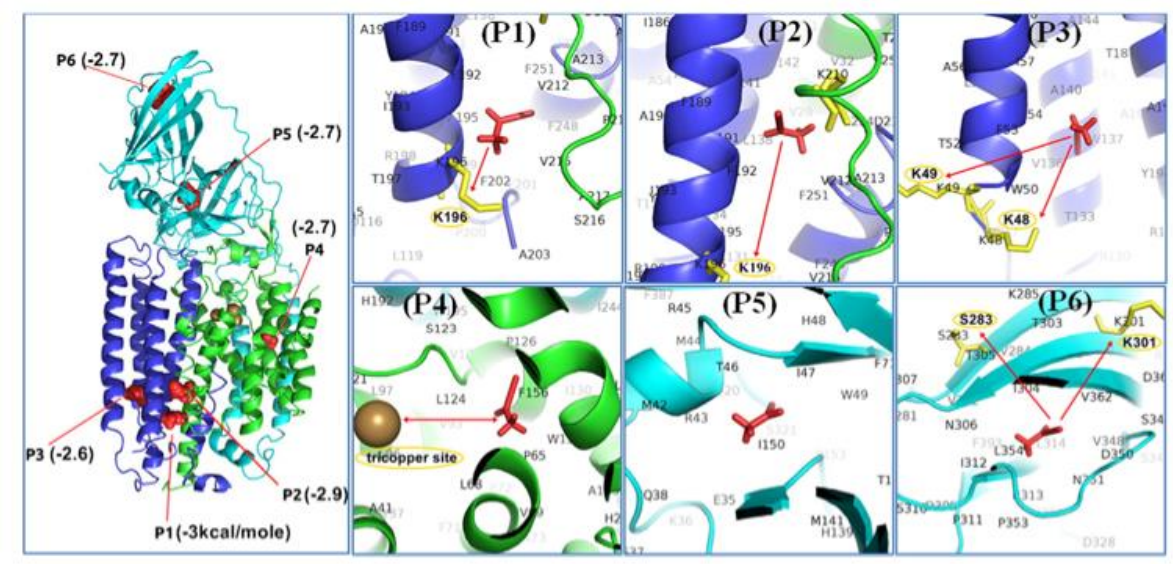

Figure 2. Molecular docking of methylketene to pMMO (Reprinted with permission of the publisher ${ }^{27}$ ). 
Irradiation of benzene on a silica surface with a pulsed glow discharge in the presence and absence of oxygen resulted in the formation of ketene (2), $\mathrm{C}_{3} \mathrm{O}(\mathbf{8})$, and ketenyl radical 9, as detected by IR spectroscopy (Scheme 5). ${ }^{28}$ It was suggested that oxygen in the products originated from the silica surface. Irradiation of benzene- $d_{6}$ gave dideuteroketene $\left(\mathbf{2}-d_{2}\right)$ and monodeuteroketenes $\left(\mathbf{2}-d_{1}\right)$, in which the protium arose from pentadeuterobenzene in the benzene sample.

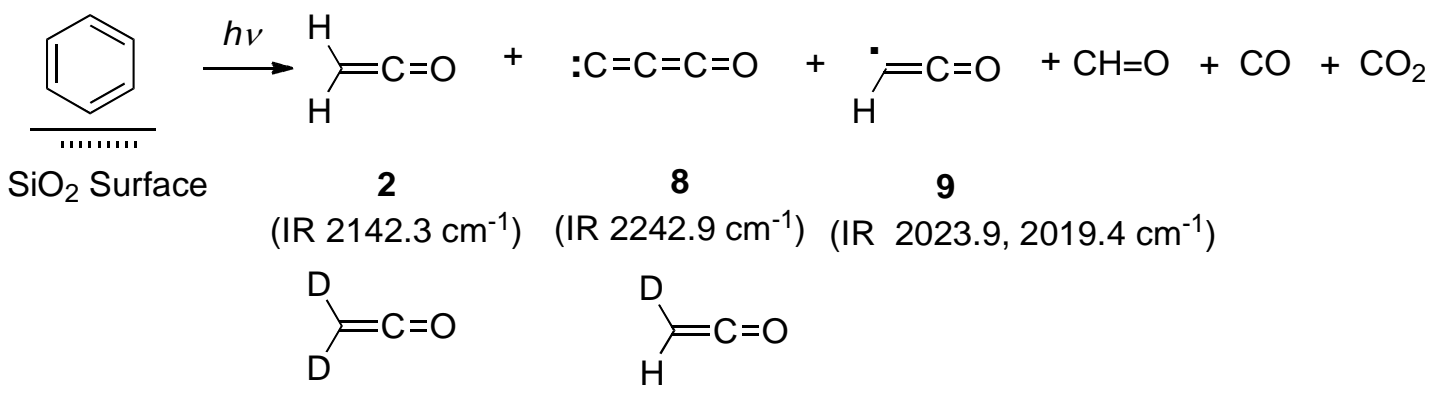

$$
\text { 2- } d_{2}\left(\mathrm{IR} 2259.9 \mathrm{~cm}^{-1}\right) \text { 2- } d\left(\mathrm{IR} 2131.9 \mathrm{~cm}^{-1}\right)
$$

Scheme 5. Benzene photolysis on a silica surface.

The ketenyl radical (9) has also been observed as an abundant molecule in interstellar space, and in the cold dark clouds Lupus-1A and L486. ${ }^{29}$ The mechanism for formation of 9 (Scheme 6) is suggested to have a much larger formation constant than used in current models. ${ }^{30,31}$ The role of 9 in evaluating the heat release in a bluff-body combustor has also been evaluated. ${ }^{32}$

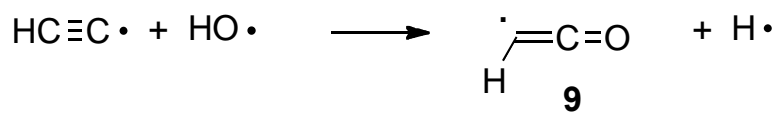

Scheme 6. Ketenyl radical formation in space.

Oxidation of phenyl radical with molecular oxygen studied experimentally with tunable vacuum ultraviolet photoionization in conjunction with a combustion simulating chemical reactor at $873 \mathrm{~K}$ and $1003 \mathrm{~K}$ showed the formation of ortho-benzoquinone, phenoxy radical, cyclopentadienyl radical, furan, acrolein, ketene, and acetylene. ${ }^{33}$ The last four products arise through ring opening and fragmentation of the seven-membered ring 2-oxepinyloxy radical 10 through the intermediacy of the ring-opened ketene radical 11 [1,6-dioxo-3,5-hexadien-2-yl $\left(\mathrm{C}_{6} \mathrm{H}_{5} \mathrm{O}_{2}\right)$ radical] (Scheme 7). 


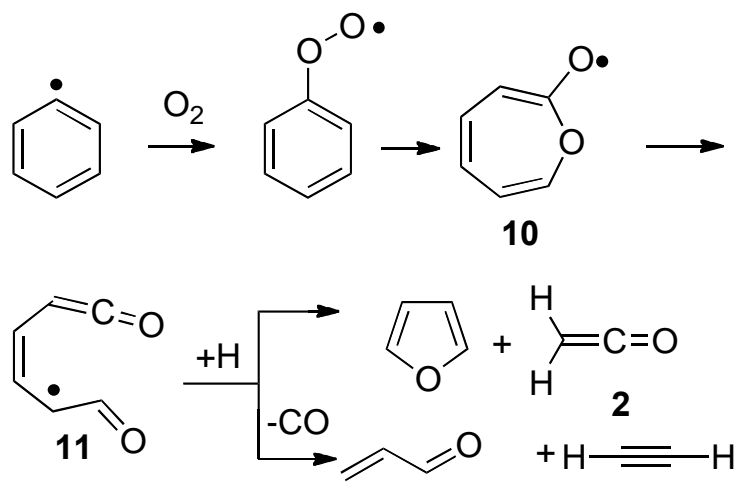

Scheme 7. Ketene formation from phenyl radical oxidation.

The formation of ketene from reaction of ground-state atomic oxygen $\mathrm{O}\left({ }^{3} \mathrm{P}\right)$ reaction with vinyl radical has been examined using crossed-beam vacuum-ultraviolet laser-induced fluorescence spectroscopy together with $a b$ initio calculations. The reaction with vinyl radical produces ketene by $\mathrm{O}$ addition and loss of a hydrogen atom (Scheme 8). ${ }^{34,35}$<smiles>C=CC=CC=O</smiles>

Scheme 8. Ketene formation from vinyl radical reaction with atomic oxygen.

Peptide extension of doubly protonated $\mathbf{1 2}$ in the gas phase by reaction with ketenimine $\mathbf{1 3}$ is proposed to occur by acylation on carbon forming an enol ester $\mathbf{1 4}$ and rearrangement to $\mathbf{1 5}$ followed by cleavage with loss of the ketene $\mathbf{1 6}$ and the extended peptide $\mathbf{1 7}$ (Scheme 9). ${ }^{36}$

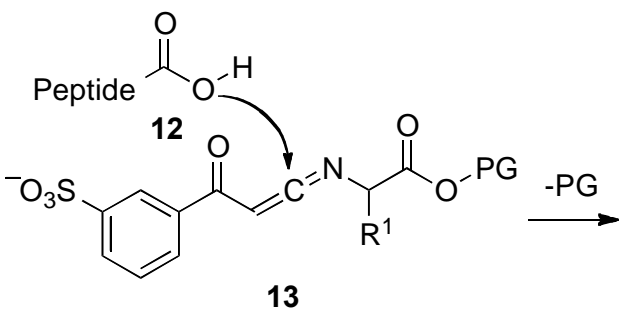<smiles>COS(=O)(=O)c1cccc(C(=O)C=C(NC(=O)C(=O)O)C(=O)O)c1</smiles>

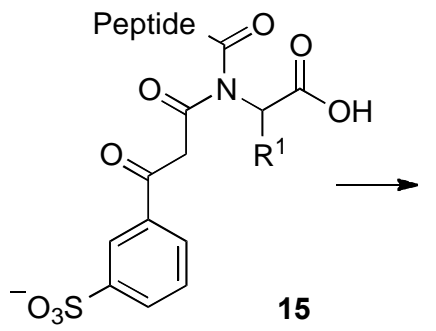<smiles>O=C=CC(=O)c1cccc(S(=O)(=O)O)c1</smiles>

Scheme 9. Ketene formation by mass spectrometric ion/ion reaction. 


\subsection{Ketenes by ring opening of cyclobutenones}

Thermal and photochemical ring openings of cyclobutenones are widely used methods for generation of vinylketenes, and applications of these reactions have been reviewed. ${ }^{3}$ Thermolysis of cyclobutenone $\mathbf{1 8}$ in toluene gave the quinone $\mathbf{2 0}$ in 69\% yield via intramolecular [4+2] cycloaddition of the ene-yne ketene $\mathbf{1 9}$ (Scheme 10). ${ }^{37}$ Treatment of the crude product with $\mathrm{TiCl}_{4}$ led to (-)-taiwaniaquinone (21) (Scheme 8). ${ }^{38}$
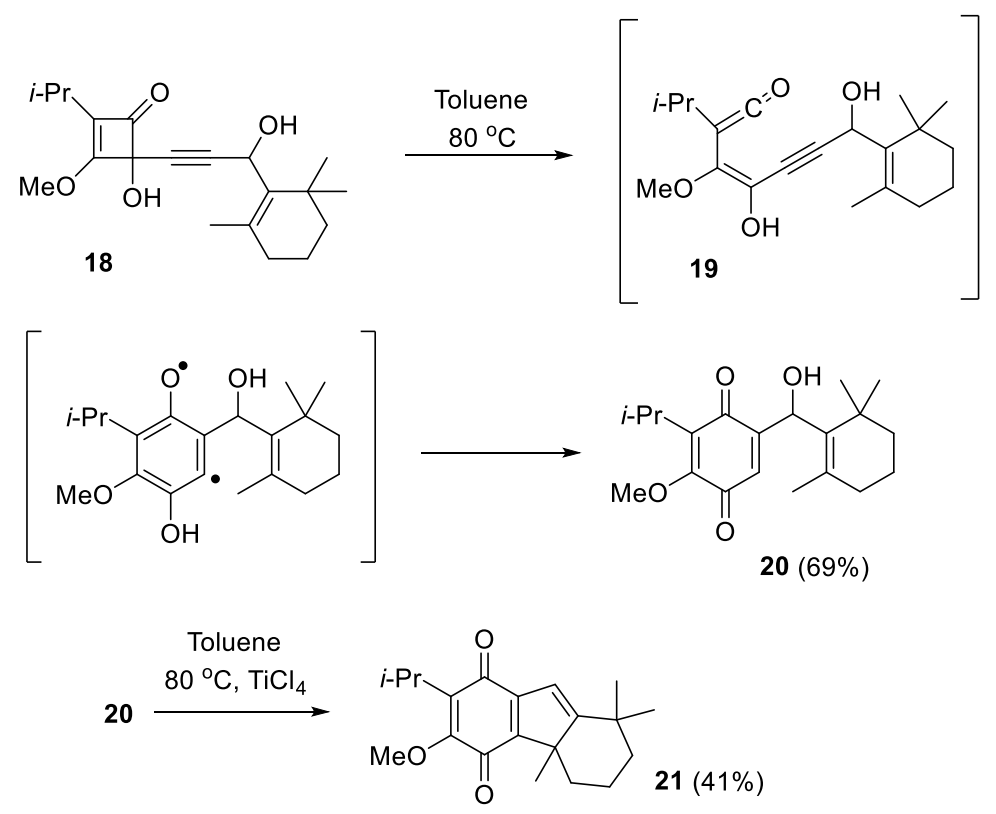

Scheme 10. Quinones by ene-yne ketene cycloaddition.

Cyclobutenone ring opening catalyzed by $\mathrm{Ni}(\mathrm{COD})_{2}$ gave net [4+2] vinylketene cycloaddition with 1-phenylhexyne in a reaction interpreted as proceeding through complex $\mathbf{2 2}$, leading to the isomeric phenols 23 (Scheme 11). ${ }^{39}$
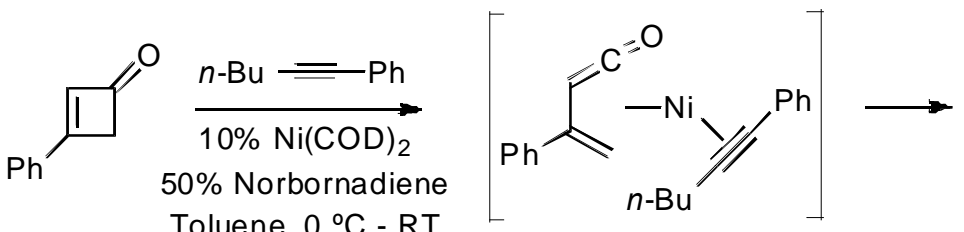

22<smiles>CCCCc1cc(-c2ccccc2)cc(O)c1-c1ccccc1</smiles>

$23 a$<smiles>CCCc1c(O)cc(-c2ccccc2)cc1-c1ccccc1</smiles>

23b

Scheme 11. Phenol formation by vinylketene/alkyne cycloaddition. 
Rhodium-catalyzed benzocyclobutenone ring expansion with DPPP ligand [1,3-bis(diphenylphosphino)propane] was tested in the presence of nucleophiles, but this did not capture a ketene intermediate. Therefore it was concluded that the reaction proceeded through a rhodium-bridged intermediate leading to the product, and a ketene intermediate was not involved. This mechanism was tested with deuterium labeling (Scheme 12). ${ }^{40}$

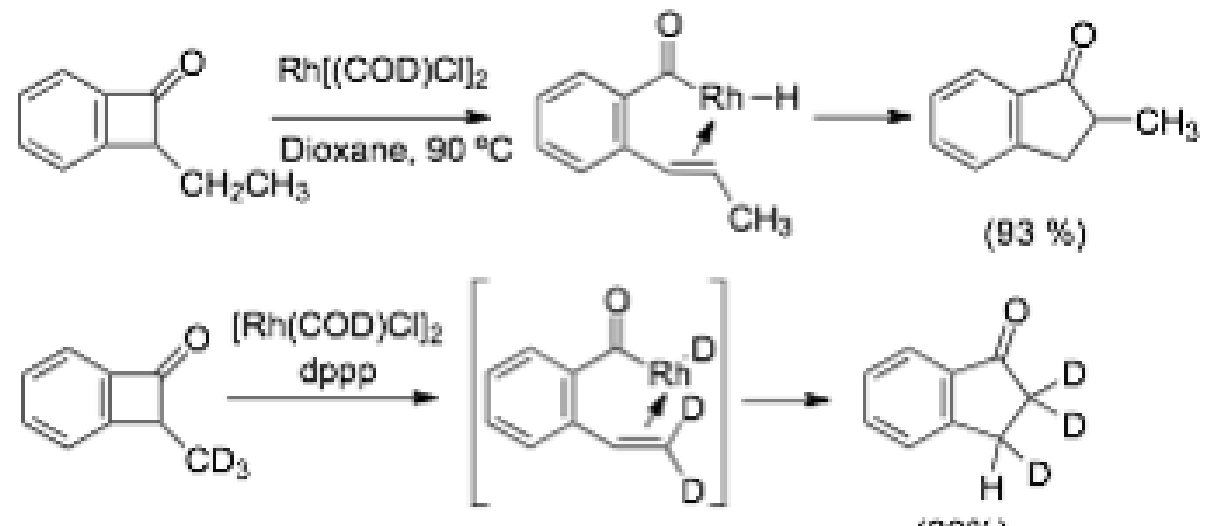

(30\%)

Scheme 12. Rhodium catalyzed benzocyclobutenone ring expansion.

The trifluoromethyl-substituted cyclobutenone $\mathbf{2 4}$ upon thermolysis undergoes ring opening to trifluoromethyl(arylvinyl)ketene $\mathbf{2 5}$, which after cyclization and oxidation gives the product naphthoquinone 26 (Scheme 13). ${ }^{41}$

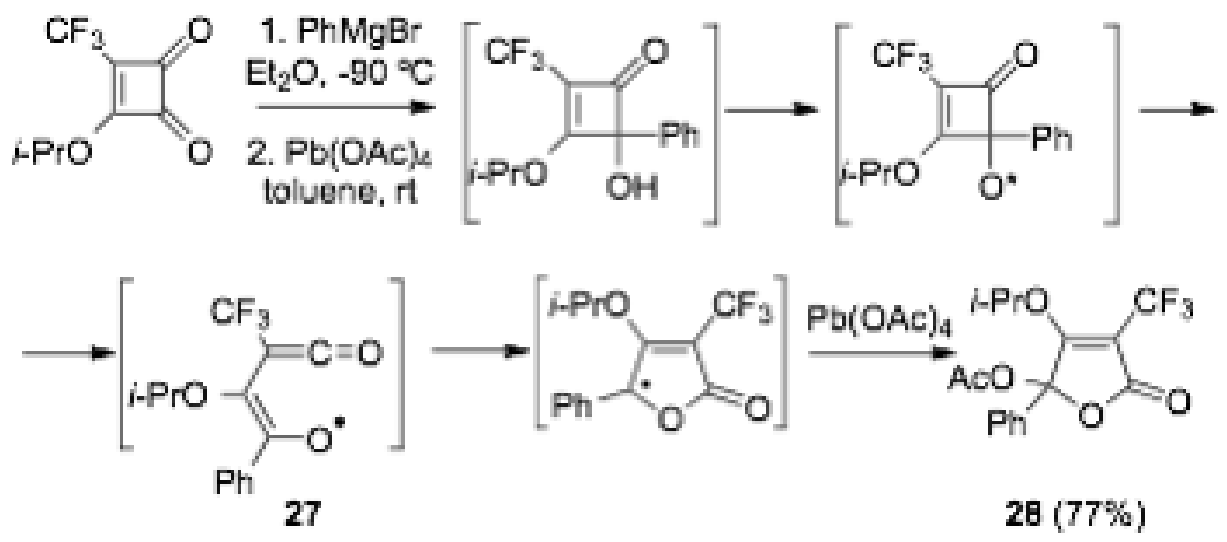

Scheme 13. Cyclization of a trifluoromethyl(oxyvinyl)ketene intermediate.

Lead tetraacetate oxidation of the aryl Grignard adducts from the same cyclobutenedione forms ketenyl radicals $\mathbf{2 7}$ which cyclize to furanones such as $\mathbf{2 8}$ (Scheme 14). ${ }^{41}$ 

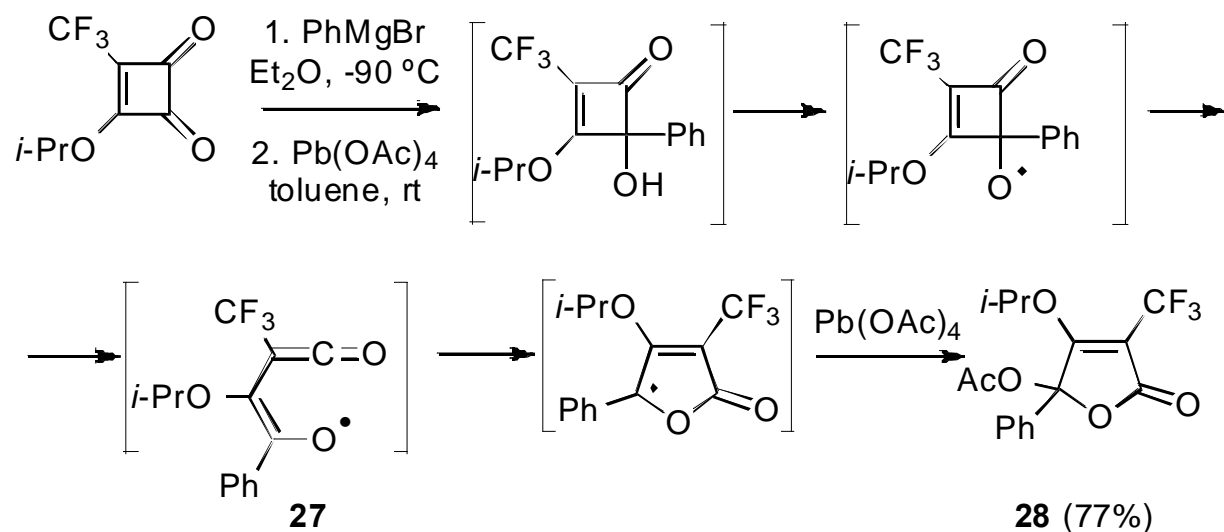

Scheme 14. Ketenyl radical formation by hydroxycyclobutenol oxidation with lead tetraacetate.

\subsection{Ketenes from diazo-ketones}

Photolysis of 2-diazo-1,2-naphthoquinone in methanol or acetonitrile/methanol is interpreted by Stern-Volmer analysis as occurring by formation of ketene $\mathbf{2 9}$ by concerted Wolff rearrangement, and by a stepwise reaction involving a carbene intermediate 30. The ketene is captured by methanol forming the ester 31, with partial capture of the carbene by methanol forming the phenol 32; capture by acetonitrile forming 2-methylnaphth[2,1-d] oxazole (33) is also observed (Scheme 15). ${ }^{42}$ It was concluded that a substantial part of the hot nascent carbene $\mathbf{3 0}$ formed by photolysis rearranges to the ketene $\mathbf{2 9}$ during its vibrational relaxation.

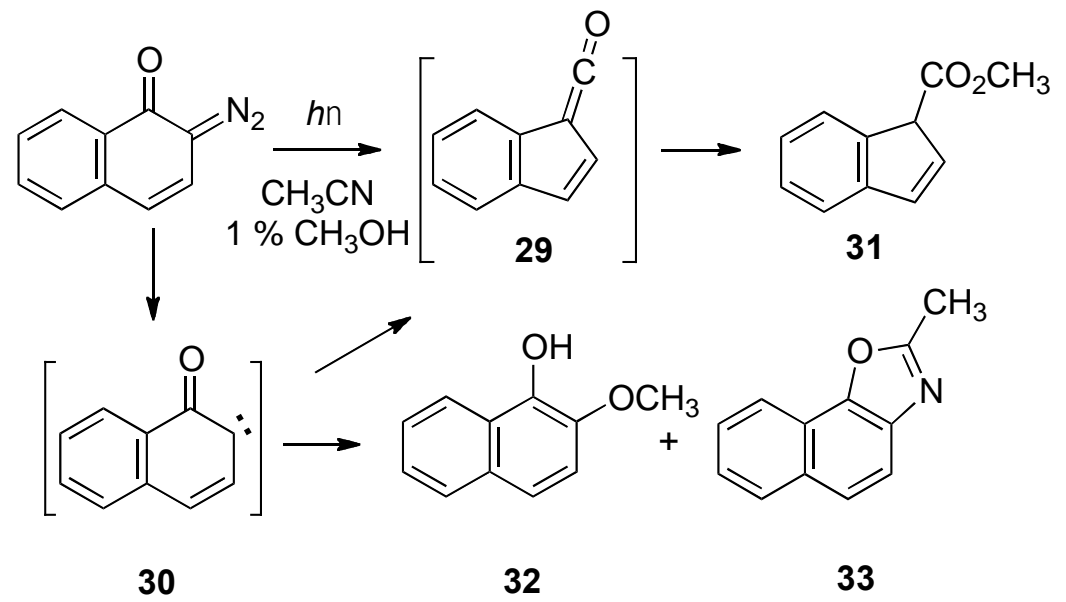

Scheme 15. Ketene formation by photochemical Wolff rearrangement.

Reaction of the ruthenium complex $\mathbf{3 4}$ with ethyl diazoacetate gave stannylketene $\mathbf{3 5}$, characterized by X-ray and the distinctive ketenyl IR absorption at $2074 \mathrm{~cm}^{-1}$ (Scheme 16). ${ }^{43}$ 


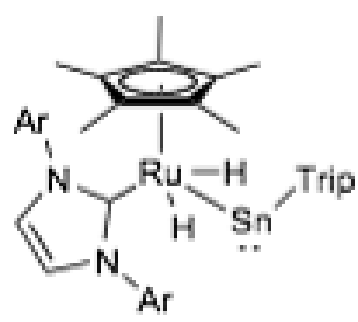

$34\left(\mathrm{Ar}=2,6-\mathrm{Me}_{2} \mathrm{C}_{6} \mathrm{H}_{3}\right.$. Trip $\left.=2,4,6-i-\mathrm{Ppr}_{3} \mathrm{C}_{6} \mathrm{H}_{2}\right)$

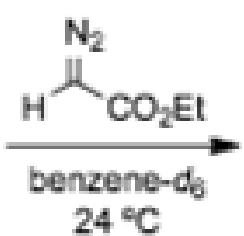

$24^{\circ} \mathrm{C}$

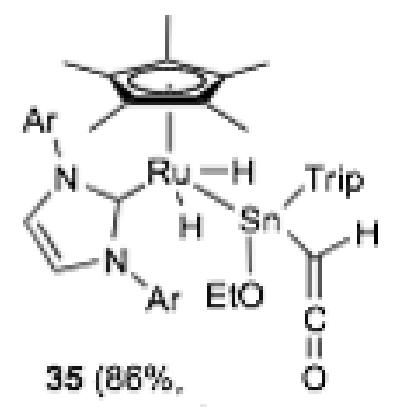

IR $2074 \mathrm{~cm}^{-1}$ )

Scheme 16. Stannylketene formation from ruthenium complex 34 with ethyl diazoacetate.

2-Pyridylketene (36) is formed by Wolff rearrangement of the corresponding diazo ketone, observed by IR at $2127 \mathrm{~cm}^{-1}$, and captured by nucleophiles (Scheme 17). ${ }^{44}$ Ketenes substituted with pyrrolyl ${ }^{45}$ pyrazinyl, ${ }^{46}$ and pyrimidinyl groups are also formed by Wolff rearrangements of the relevant diazoketones, ${ }^{46}$ and similar bisketenes are generated by ring opening of bis(diazoacetyl) precursors (Scheme 17) ${ }^{46}$ The formation of $\mathbf{3 7}$ was confirmed by observation of the ketenyl IR absorption at 2123 and $2133 \mathrm{~cm}^{-1}$ in acetonitrile. ${ }^{46}$<smiles>N=CC(=O)c1ccccn1</smiles>

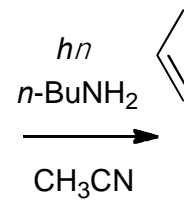<smiles>O=C=Cc1ccccn1</smiles><smiles>CCCCNC(=O)Cc1ccccn1</smiles>

36<smiles>N#CC(=O)c1cnc(C(=O)C=[W])cn1</smiles><smiles>COC</smiles><smiles>O=C=Cc1cnc(C=C=O)cn1</smiles>

37<smiles>CC(=O)CCc1cnc(CC(C)=O)cn1</smiles>

Scheme 17. Formation of 2-pyridylketene (36) and of pyrazinylbisketene (37) by Wolff rearrangement.

\subsection{Ketenes by other photolytic, thermolytic and mass spectral methods}

Gas-phase pyrolysis of 3-oxetanone in a hyperthermal nozzle begins at $600{ }^{\circ} \mathrm{C}$, and proceeds with cleavage to ethylene oxide and carbon monoxide, as well as ketene and formaldehyde (Scheme 18). ${ }^{47}$ 


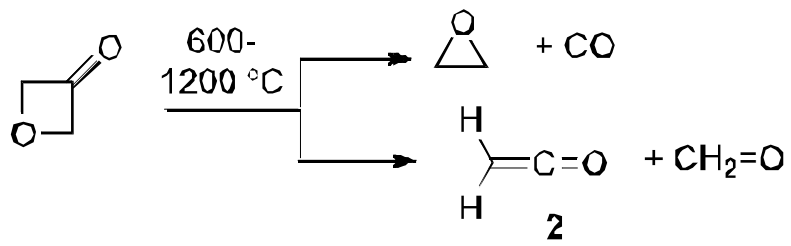

Scheme 18. Ketene formation by 3-oxetanone pyrolysis.

The 9-methylhexahydroacridinedione radical cation $\mathbf{3 8}$ is proposed to give mass spectral fragmentation to the fused 5-oxoquinolinium ion $\mathbf{3 9}$ with loss of a methyl radical and ketene (Scheme 19). ${ }^{48}$

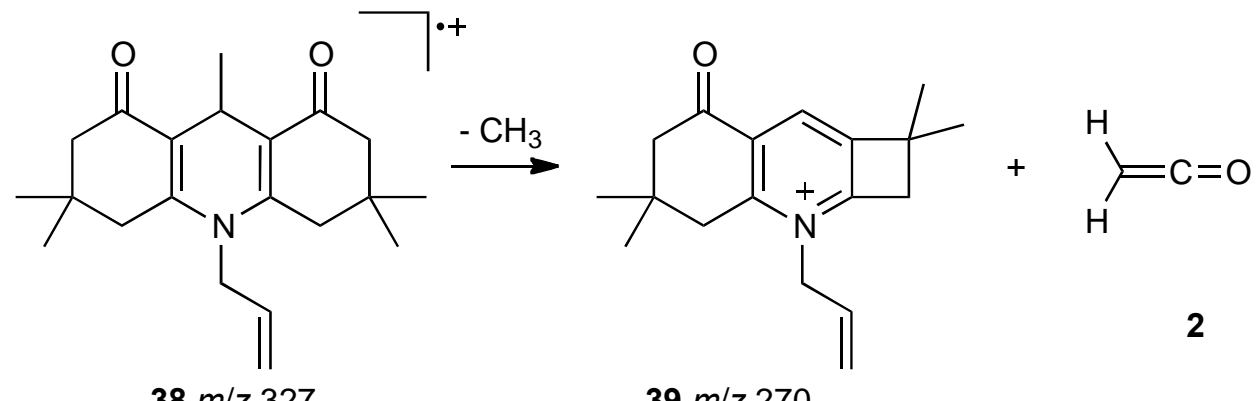

$38 \mathrm{~m} / \mathrm{z} 327$

$39 \mathrm{~m} / \mathrm{z} 270$

Scheme 19. Ketene formation by acridinedione radical ion decomposition.

Photolysis of 2-acetylbenzaldehyde forms the ketene intermediate 40, with IR absorption at $2080 \mathrm{~cm}^{-1}$, which is suggested to form from an initial biradical intermediate within 2-3 ps, as observed by femtosecond stimulated Raman spectroscopy. The ketene has a lifetime of $1.4 \mu \mathrm{s}$ and leads to 3-methylphthalide $\mathbf{4 1}$ with a quantum yield of $30 \%$ (Scheme 20). ${ }^{49}$<smiles>CC(=O)c1ccccc1C=O</smiles><smiles>CC(C)N</smiles><smiles>CC(O)=c1ccccc1=C=O</smiles>
$40\left(\right.$ IR $\left.2080 \mathrm{~cm}^{-1}\right)$<smiles>CC1OC(=O)c2ccccc21</smiles>

Scheme 20. Ketene formation by photolysis of 2-acetylbenzaldehyde.

Thiophenone 42 upon photolysis in $\mathrm{CH}_{3} \mathrm{CN}$ gives IR absorption in the range 2000-2220 $\mathrm{cm}^{-1}$, ascribed to ring opening forming ketenes $\mathbf{4 3}$ (Scheme 21) which revert to $\mathbf{4 2}$ with $60 \%$ efficiency. ${ }^{50}$ Furanone 44 reacts similarly giving IR absorption in the range $2020-2180 \mathrm{~cm}^{-1}$, ascribed to ketenes $\mathbf{4 5}$ (Scheme 21), which gives less than $10 \%$ reformation of $\mathbf{4 4} .^{50} \mathrm{Ab}$ initio 
calculations of the reaction mechanism suggest an important role for dissociative $(n / \pi) \sigma^{*}$ states in these reactions (Figure 3 ).

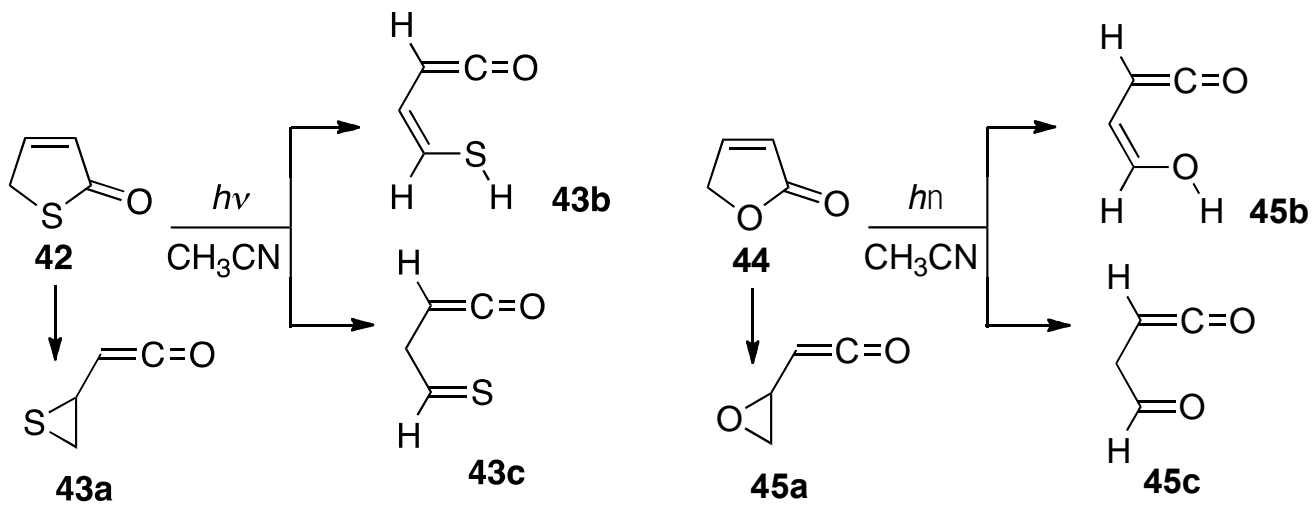

Scheme 21. Ketene formation by thiophenone and furanone photolysis.
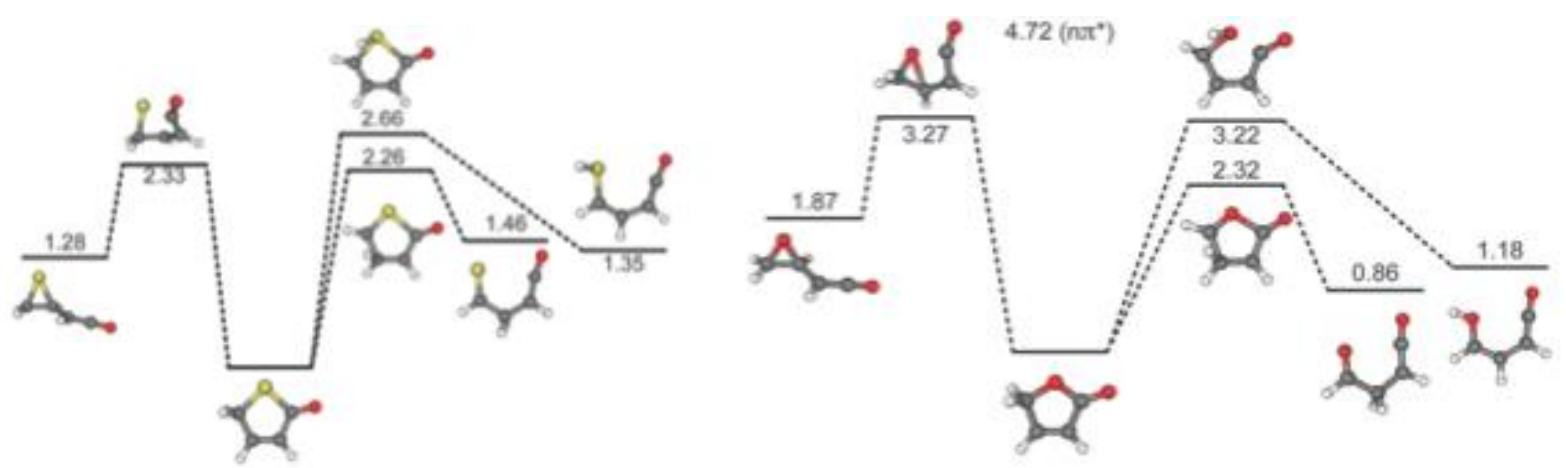

Figure 3. Calculated ketene formation from thiophenone and furanone (Reprinted with permission of the publisher ${ }^{50}$ ).

Computations based on electronic structure calculations and dynamics simulations of photoinduced reactions of 2-formyl-2 $\mathrm{H}$-azirine and isoxazole reveal that isoxazole (46) gives an excited state 47 which forms $\mathrm{HCN}$ and the $\mathrm{CHCHO}$ diradical 48 through the transition state TSCC_VN_S0 (Fig. 4), and the diradical forms ketene through a 1,2-hydrogen shift reaction (Scheme 22). ${ }^{51}$

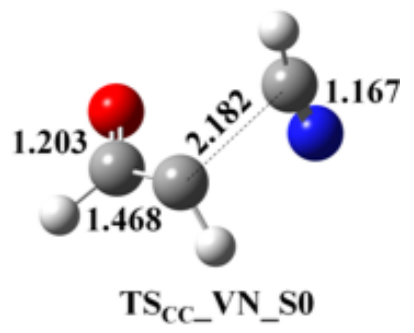

Figure 4. Calculated structure of $\mathrm{TS}_{\mathrm{CC}}$ VN_SO (Reprinted with permission of the publisher ${ }^{51}$ ). 


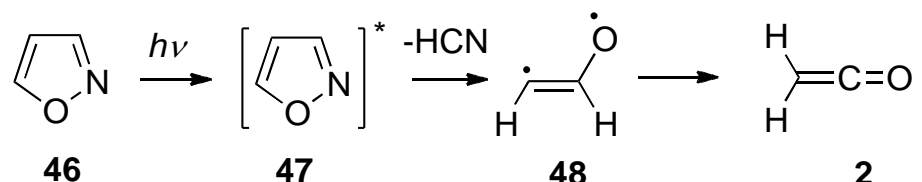

Scheme 22. Ketene formation by isoxazole photolysis.

Matrix photolysis of anisole results in formation of a radical pair followed by recombination at the 2- and 4-positions forming isomeric cyclohexadienones, which lead to the open-chain ketene 49 and other products (Scheme 23). ${ }^{52}$

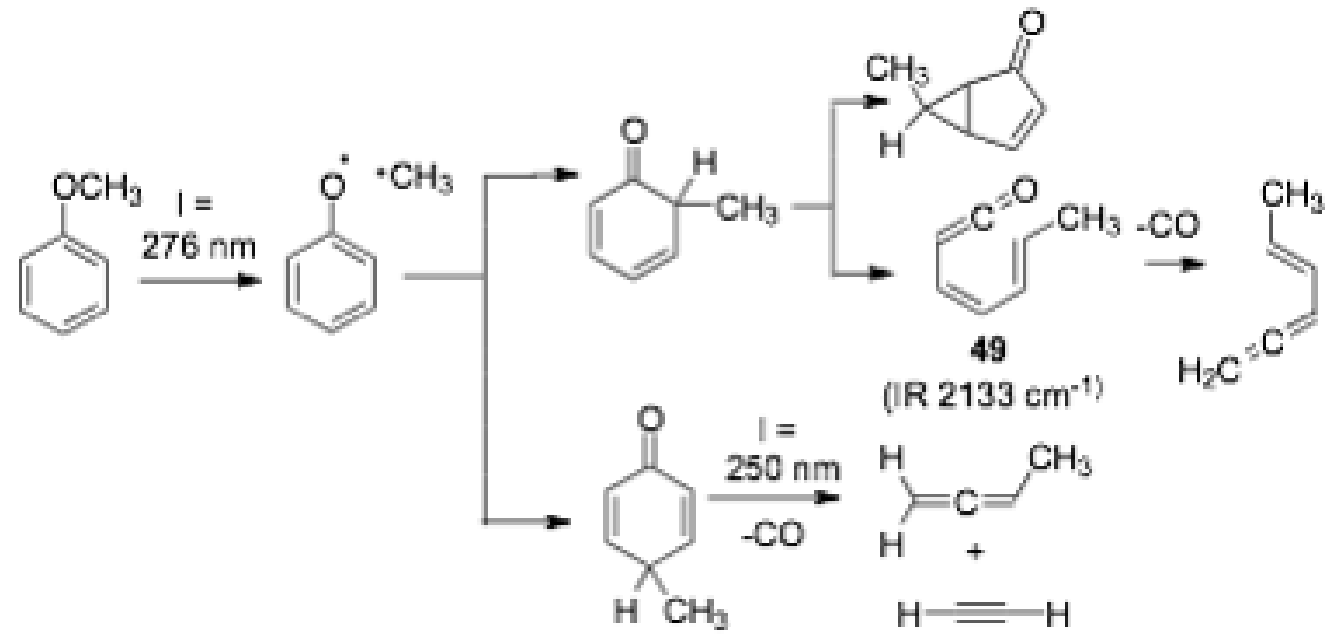

Scheme 23. Matrix photolysis of anisole.

Photolysis of 5-hydroxyquinoline, forming ketene 50, was studied by matrix isolation spectroscopy and computations (Scheme 24). ${ }^{53}$ The ketene was identified by its characteristic IR absorption in the region $2112-2129 \mathrm{~cm}^{-1}$.

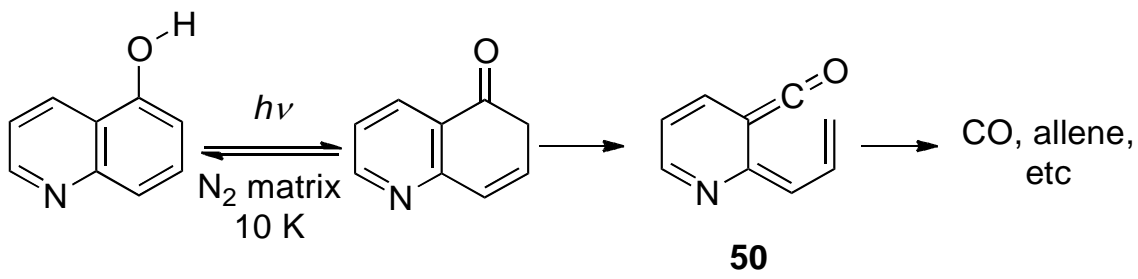

(IR $2112-2129 \mathrm{~cm}^{-1}$ )

Scheme 24. Ketene formation by 5-hydroxyquinoline photolysis. 


\subsection{Ketenes from carbonylation processes}

A radiation-induced process of methanol-carbon monoxide ices produces ketene among other small molecules (Scheme 25). ${ }^{54}$ Ketene IR bands using isotope-labeled ices of methanol-carbon monoxide were also identified at $2107 \mathrm{~cm}^{-1}\left(\mathrm{H}_{2} \mathrm{C}=\mathrm{C}={ }^{18} \mathrm{O}\right)$ and at $2067 \mathrm{~cm}^{-1}\left(\mathrm{H}_{2}{ }^{13} \mathrm{C}={ }^{13} \mathrm{C}=\mathrm{O}\right) .{ }^{54}$

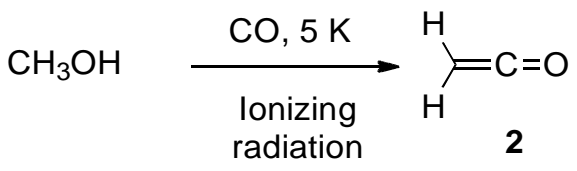

Scheme 25. Ketene formation from irradiation in methanol-carbon monoxide ice.

Photolysis of the Fischer chromium complex $\mathbf{5 1}$ using low temperature matrix isolation with picosecond time resolved observation indicated the formation of the chromium ketene complex 52, as detected by IR absorption at 1777 and $1990 \mathrm{~cm}^{-1}$, consistent with time-dependent density function calculations (Scheme 26). ${ }^{55}$

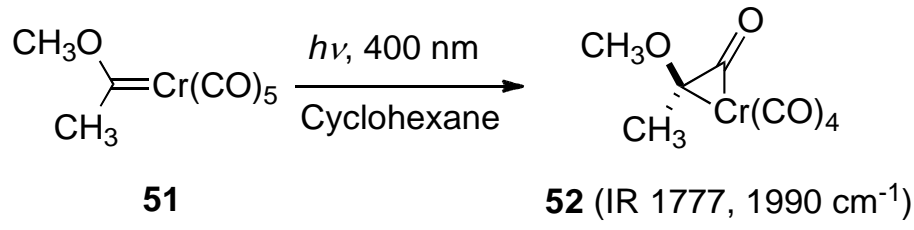

Scheme 26. Chromium ketene complex formation by carbene complex photolysis.

An independent study ${ }^{56}$ of this system as well as of the corresponding tungsten complex found that, in contrast to the previous work, which indicated triplet states in the case of the chromium complex, no evidence for the formation of triplet states was observed. The later investigators preferred the reaction path forming structures 53 and 54 (Scheme 27). ${ }^{56}$

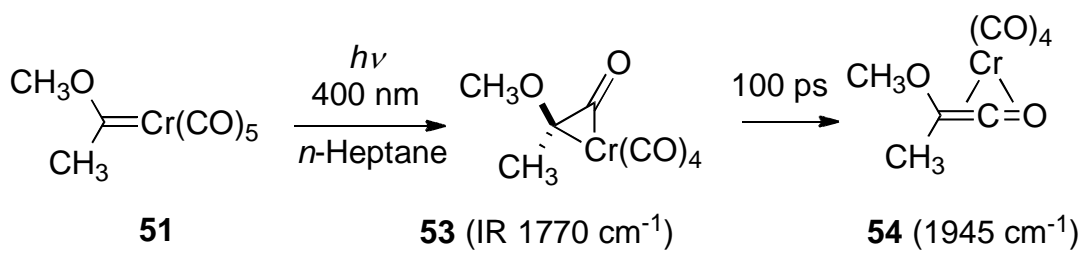

Scheme 27. Alternative interpretation of chromium ketene complex formation by carbene complex photolysis.

Reaction of cluster arachno- $\left[\mathrm{Cp} * \mathrm{Mo}(\mathrm{CO})_{2} \mathrm{~B}_{3} \mathrm{H}_{8}\right](\mathbf{5 5})$ with $\left[\mathrm{Ru}_{3}(\mathrm{CO})_{12}\right]$ gave the stable heterometallic ketenylidene cluster $\left[\mathrm{Cp} * \mathrm{Mo}(\mathrm{CO})_{2}(\mu-\mathrm{H}) \mathrm{Ru}_{2}(\mathrm{CO})_{6}(\mu 3-\eta 1-\mathrm{CCO})\right] \mathbf{5 6}$ (Scheme 28) 
as red crystals, IR $\left(\mathrm{C}=\mathrm{C}=\mathrm{O}, 1799 \mathrm{~cm}^{-1}\right)$, together with $\left[\mathrm{Cp} * \mathrm{Mo}(\mathrm{CO})_{2}\left\{\mathrm{Ru}(\mathrm{CO})_{3}\right\}_{4} \mathrm{~B}\right]$, with the structure of 56 established by single-crystal X-ray crystallographic analysis. ${ }^{57}$

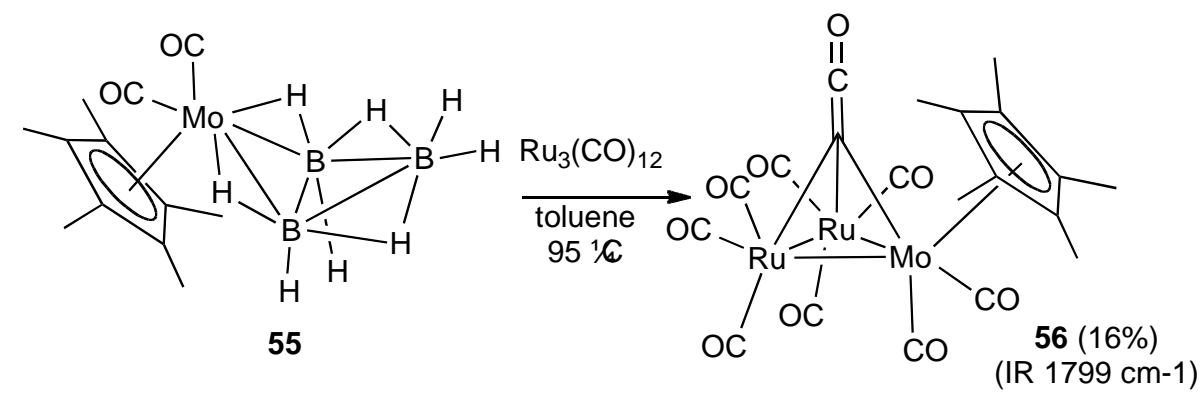

Scheme 28. Formation of a ketenylidene molybdenum-ruthenium complex.

Carbon monoxide reduction by lithium disilenide $\mathbf{5 7}$ forms a silanone dimer $\mathbf{5 9}$ proposed to form through the ketenyl intermediate 58. ${ }^{57}$ Related ketenyl species $\mathbf{6 0}$ (Figure 5)and $\mathbf{6 1}$ were also prepared from 57 (Scheme 29) and characterized. ${ }^{57}$

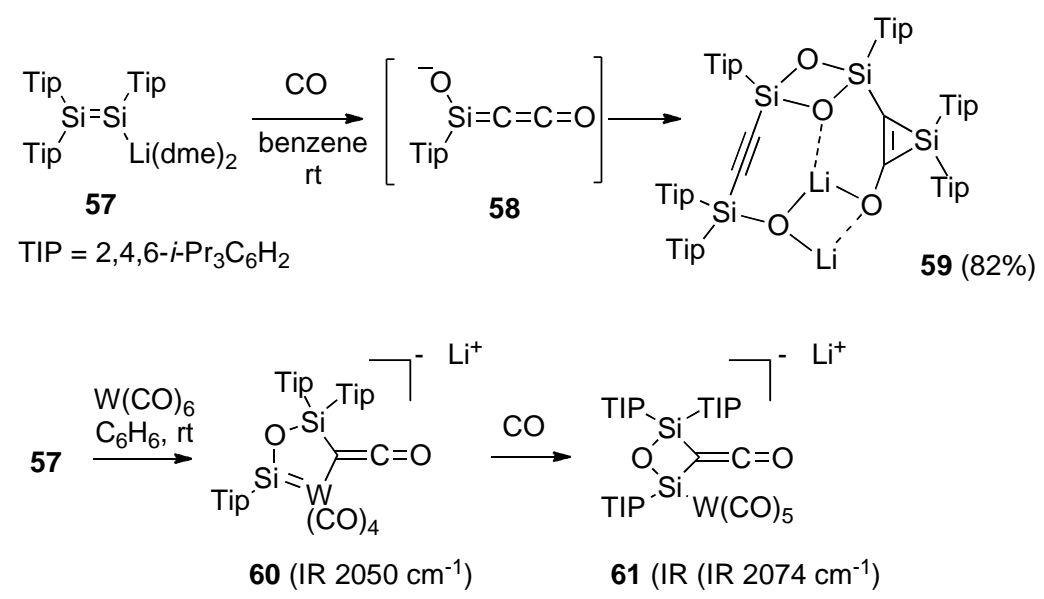

Scheme 29. Silanone formation by carbon monoxide reduction of a lithium disilenide.

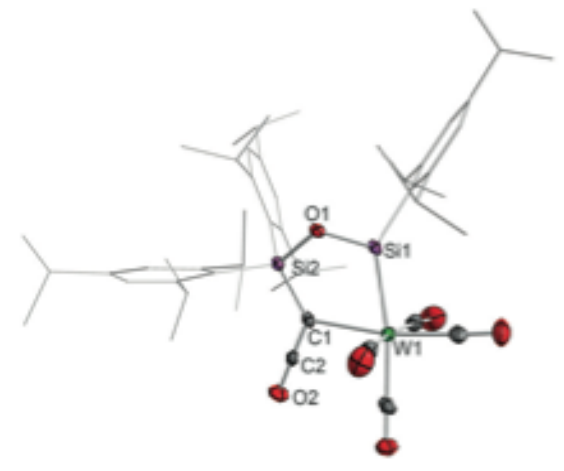

Figure 5. X-ray structure of ketenylene $\mathbf{6 0}$ (Reprinted with permission from the publisher ${ }^{58}$ ). 
Bis(trimethylsilyl)ketene (64) is proposed to be expelled during preparation of the rhodium complex 65 from reaction of 62 with the phosphine ligand 63 the presence of carbon monoxide (Scheme 30). ${ }^{59}$ Ketene 64 was identified by the distinctive ${ }^{13} \mathrm{C}$ NMR of the reaction product.

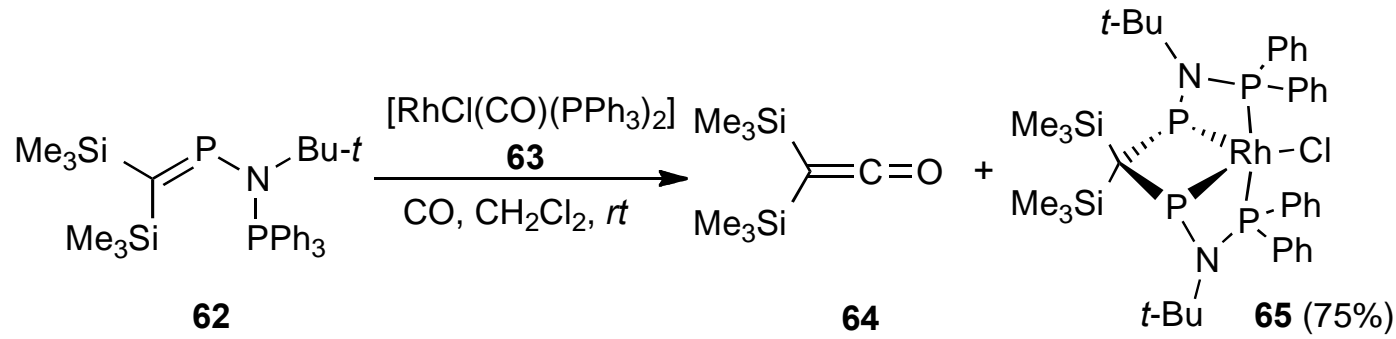

Scheme 30. Expulsion of bis(trimethylsilyl)ketene in preparation of a $\mathrm{Rh}(\mathrm{III})$-coordinated tetradentate ligand.

Rhodium catalyzed reaction of 3-acyloxy-1,4-enynes leads to resorcinol products by a mechanism calculated by DFT methods to involve a [5+1] cycloaddition with successive 1,2 acyloxy migration, $\mathrm{CO}$ insertion, and reductive elimination to ketene intermediate $\mathbf{6 6}, 6 \pi$ electrocyclization, and aromatization to 67 (Scheme 31 ). ${ }^{60}$

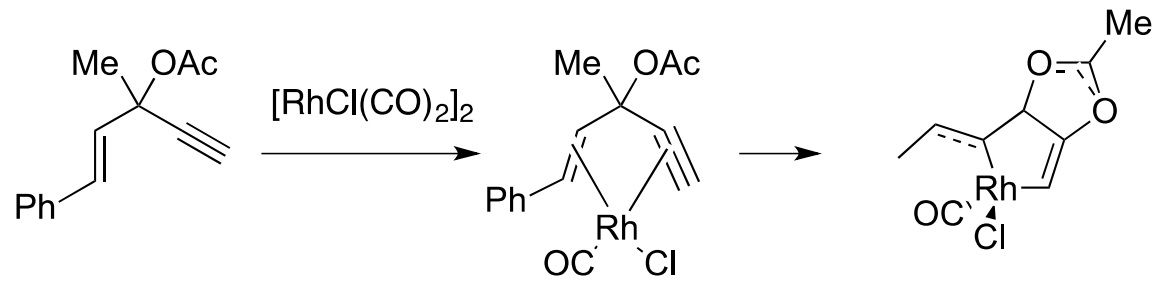

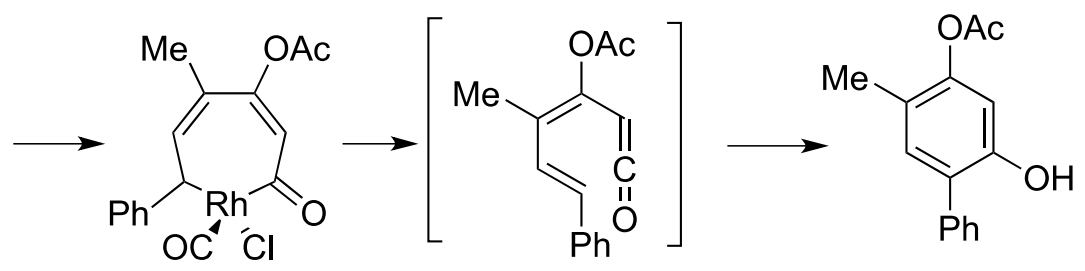

66

$67(68 \%)$

Scheme 31. Ketene formation during rhodium catalyzed reaction of 3-acyloxy-1,4-enynes.

In a study of the chemical evolution and the origin of oxygen-containing organic molecules in space, photolysis of methanol/carbon monoxide ices at $5.5 \mathrm{~K}$ using single photoionization reflection time-of-flight (ReTOF-PI) mass spectrometry detected ketene formation in ${ }^{13} \mathrm{CH}_{3} \mathrm{OH}$ and $\mathrm{CH}_{3}{ }^{18} \mathrm{OH}$ ices via the observation of the $v_{2}$ fundamental at $2067 \mathrm{~cm}^{-1}\left({ }^{13} \mathrm{CH}_{2}={ }^{13} \mathrm{C}=\mathrm{O}\right)$ and 2107 $\mathrm{cm}^{-1}\left(\mathrm{CH}_{2}=\mathrm{C}={ }^{18} \mathrm{O}\right) .{ }^{54}$ Two possible suggested routes to ketene are shown in Scheme $32 .{ }^{54}$ 


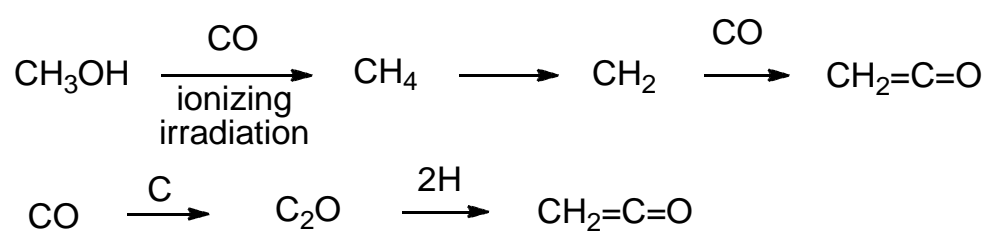

Scheme 32. Possible ketene formation from photolysis of methanol/carbon monoxide ices in space.

A particularly interesting finding is that ketene formation by the combination of $\mathrm{CH}_{2}$ with carbon monoxide is implicated in the conversion of synthesis gas to olefins in the FischerTropsch process (Scheme 33). ${ }^{61,62}$

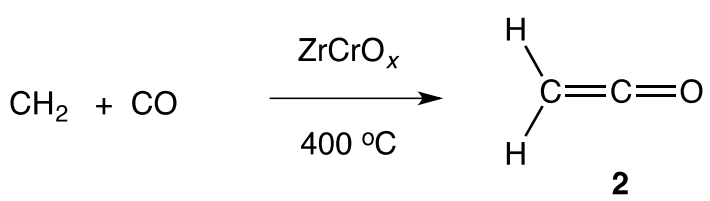

Scheme 33. Ketene formation in the Fischer-Tropsch process.

Reaction of the anti-aromatic borole $\mathbf{6 8}$ with carbon monoxide gives the boron substituted ketene 69 in a process proposed to occur by addition of $\mathrm{CO}$ followed by migration of a trimethylsilyl group (Scheme 34). ${ }^{63}$ The structure of 69 was confirmed by determination of the X-ray structure (Figure 6).

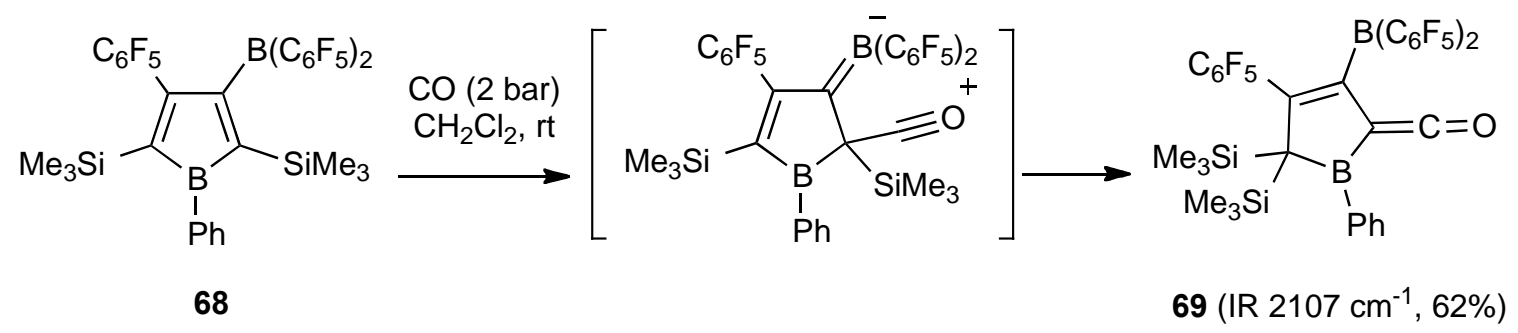

Scheme 34. Ketene formation from reaction of an antiaromatic borole with carbon monoxide. 


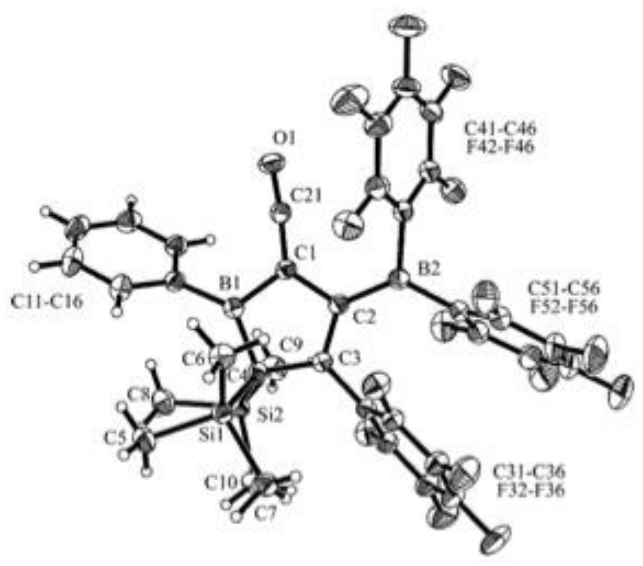

Figure 6. X-ray structure of ketene 69 (Reprinted with permission of the publisher ${ }^{63}$ ).

Intramolecular coupling of carbenes with $\mathrm{CO}$ in metal carbonyl radicals leading to ketene complexes has been examined by computational methods, and a variety of pathways are obtained for $\mathrm{M}\left(\mathrm{CH}_{2}\right)(\mathrm{CO})_{3}(\mathrm{M}=\mathrm{Co}, \mathrm{Rh}, \mathrm{Ir})$ (Figure 7). ${ }^{64}$

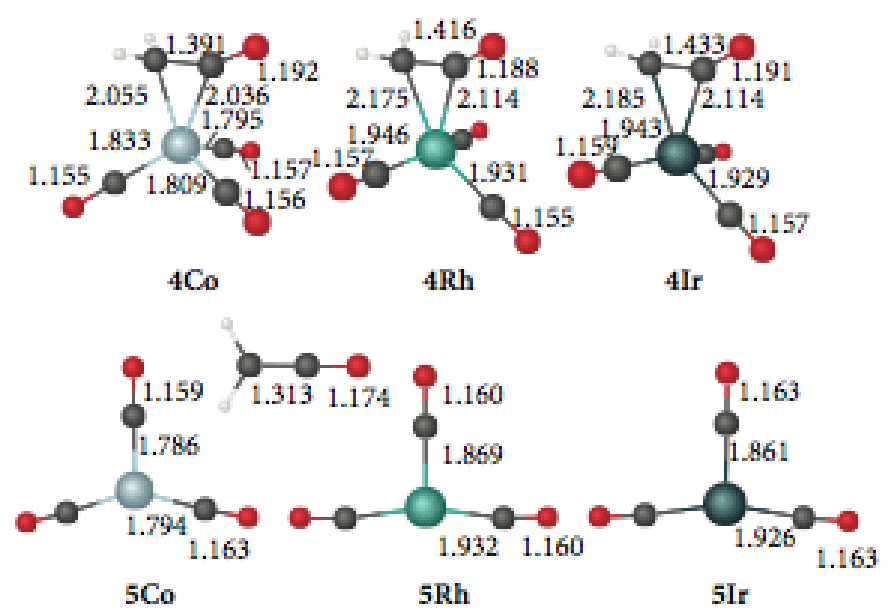

Figure 7. Coordinatively saturated ketene complexes with carbenes (Reprinted with permission of the publisher ${ }^{64}$ ).

\subsection{Ketenes from carboxylic acids and their derivatives}

Acetic acid decomposition on $\mathrm{Pt}(\mathrm{III})$ gave ketene and acetaldehyde formation as the major decomposition pathway, ${ }^{65}$ while acetic acid on $\mathrm{CeO}_{2}$ formed ketene above $500 \mathrm{~K}$ (Scheme 35). ${ }^{66}$

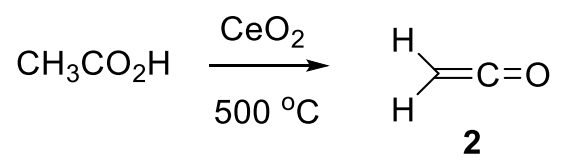

Scheme 35. Ketene formation from acetic acid on $\mathrm{CeO}_{2}$. 
Computations have been used to study the dehydration of unsaturated acids such as $\mathbf{7 0}$ forming the extended ketene $\mathbf{7 1},{ }^{67}$ as well as of other unsaturated acids to the corresponding ketenes. ${ }^{67}$ In a separate investigation dehydration of the dienyl acid $\mathbf{7 2}$ to the vinyl extended ketene $\mathbf{7 3}$ was included (Scheme 36 ). ${ }^{68}$

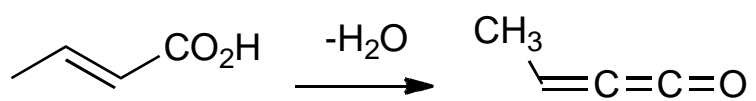

70

71<smiles>C=C/C=C/C(=O)O</smiles>

72

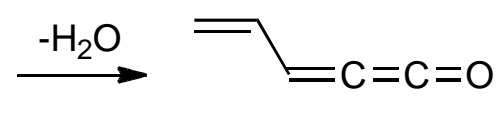

73

Scheme 36. Computational studies of extended ketene formation.

Mukaiyama's reagent (75) is used for the dehydration of 3-phenyl-2-(1H-pyrrol-1-yl)propanoic acid (74), forming ketene 76, which in the presence of benzylidene-p-anisidine reacts by $[2+2]$ cycloaddition giving the $\beta$-lactam 77 (Scheme 37). ${ }^{69}$

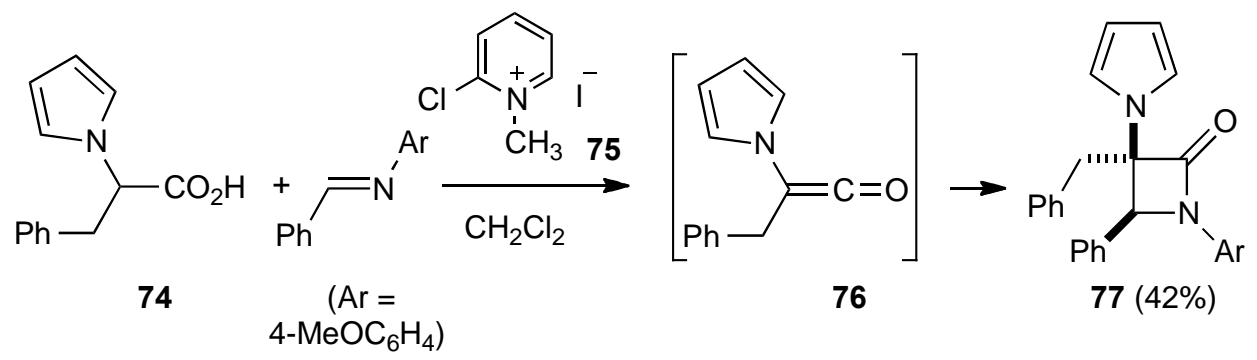

Scheme 37. Ketene formation by carboxylic acid dehydration with Mukaiyama's reagent.

Flash vacuum pyrolysis of $N$-(2-pyridyl)acetamides $\mathbf{7 8}$ generates ketenes $\mathbf{7 9}$ by elimination, and these are trapped by argon matrix isolation of the products, with characterization of the ketene products by IR absorption between 2106 and $2156 \mathrm{~cm}^{-1}$ (Scheme 38 ) ${ }^{70}$ Similar pyrolysis of $\mathbf{8 0}$ gave 2-pyridylketene (36) as well as the isocyanate 81, and the isocyanate formation is attributed to hydrogen elimination by the second pyridyl group. ${ }^{70}$ 


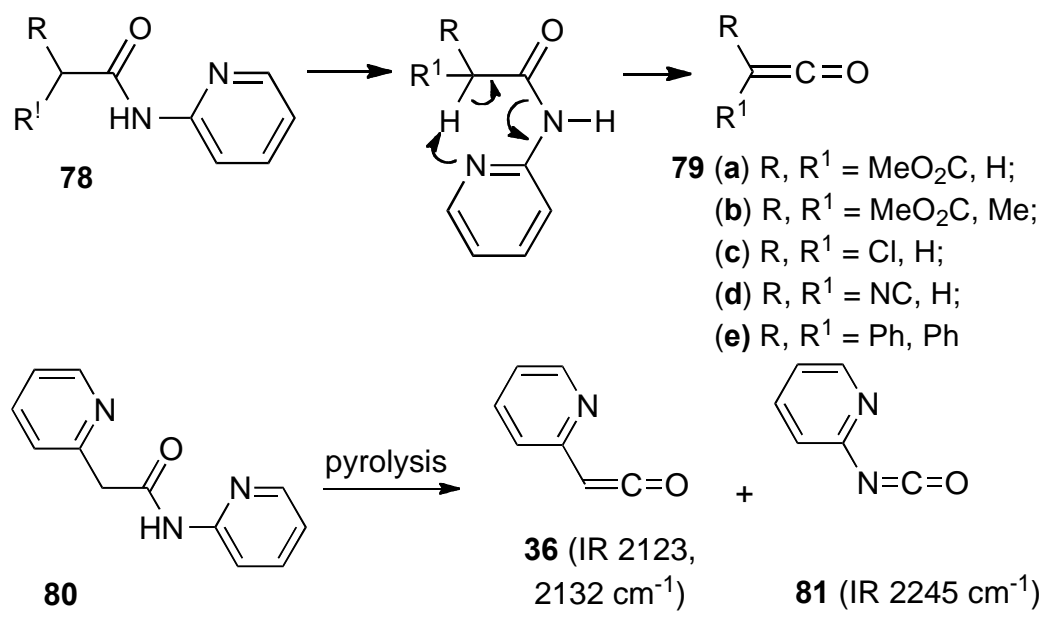

Scheme 38. Ketene formation by pyridyl ester pyrolysis.

The rather facile reaction of $N$-(2,2,6,6-tetramethylpiperidinyl) amides with methanol was studied by DFT computational methods, and it was concluded the lack of conjugation in the twisted geometry of the amide permitted hydrogen transfer from methanol to nitrogen which promoted dissociation to ketenes (Scheme 39, Figure 8). ${ }^{71}$<smiles>C=C([O-])N1C(C)(C)CCCC1(C)N(CCO)C(C)C=C=C=O</smiles>

Scheme 39. Ketene formation from twisted amides.
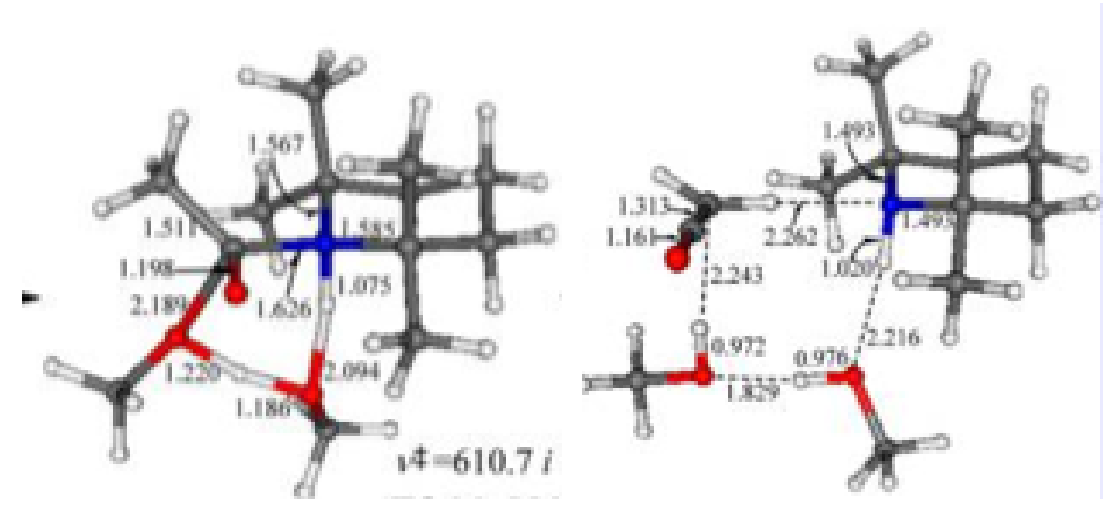

Figure 8. Facile amide methanolysis with ketene elimination (Reprinted with permission from the publisher ${ }^{71}$ ). 
Acyl ketene 84 generated from carboxylic acid $\mathbf{8 2}$ by dehydration with dicyclohexylcarbodimide reacts with the alcohol $\mathbf{8 3}$ forming ester $\mathbf{8 5}$, which is used in macrolide synthesis (Scheme 40). ${ }^{72}$
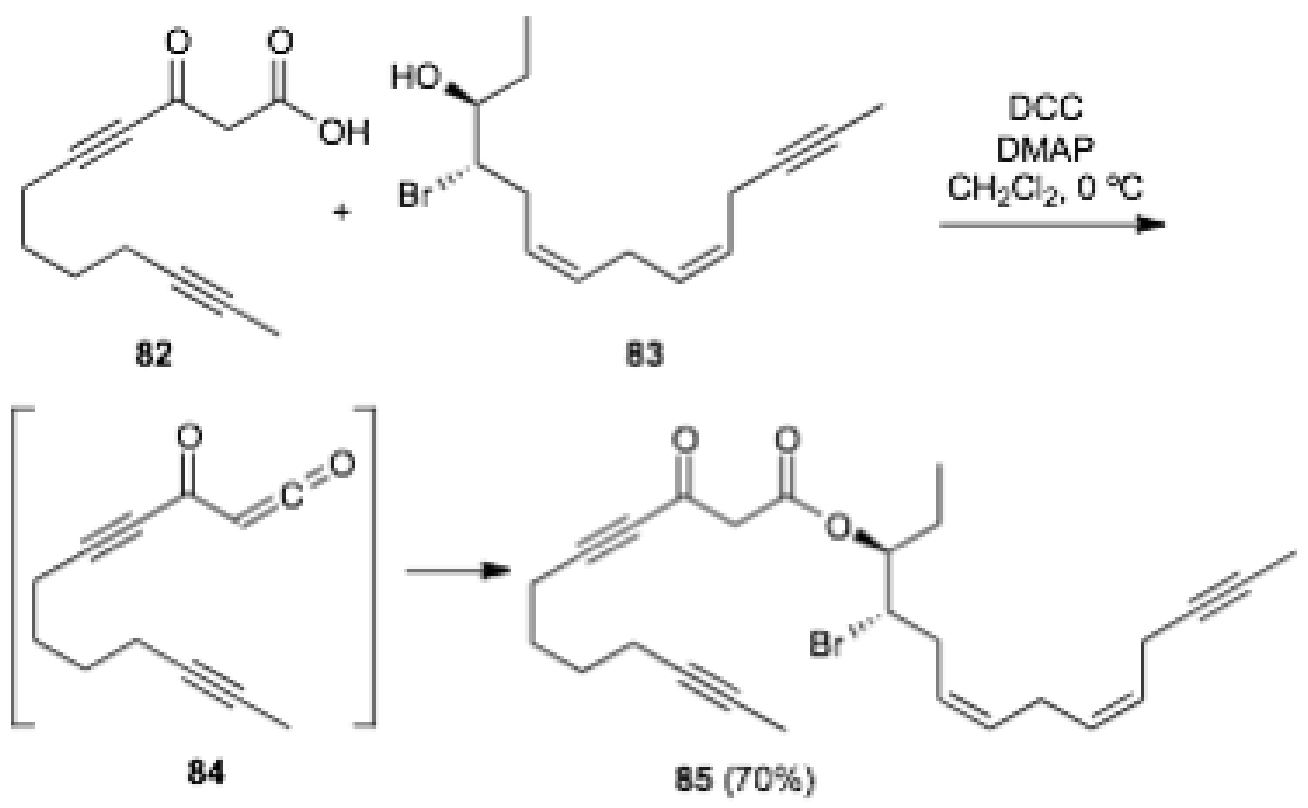

$\mathrm{DCC}=\mathrm{C}-\mathrm{C}_{6} \mathrm{H}_{11} \mathrm{~N}=\mathrm{C}=\mathrm{N}-\mathrm{C}-\mathrm{C}_{6} \mathrm{H}_{11}, \mathrm{DMAP}=4-$ Dimethylaminopyridine

Scheme 40. Ketene generation by carboxylic dehydration, followed by esterification.

Photolysis of dichloroacetyl chloride in argon matrices with product analysis by IR revealed the formation of dichloroketene, $\mathrm{Cl}_{2} \mathrm{C}=\mathrm{C}=\mathrm{O}(\mathbf{8 6})$, with absorption at $2155 \mathrm{~cm}^{-1}$, and chloroketene $\mathrm{ClCH}=\mathrm{C}=\mathrm{O}(\mathbf{8 7})$ at $2150 \mathrm{~cm}^{-1}$, both as minor products, while the major pathways involved $\mathrm{C}-\mathrm{C}$ bond cleavage. ${ }^{73}$

2-Fluorobenzoyl chloride upon photolysis in an Ar matrix underwent rotational isomerization and also formation of ketene $\mathbf{8 8}$ and dissociation leading to fluorobenzoyl radical, which upon decarbonylation forms $o$-chlorofluorobenzene, $m$-chlorofluorobenzene and CO (Scheme $41){ }^{74}$ 


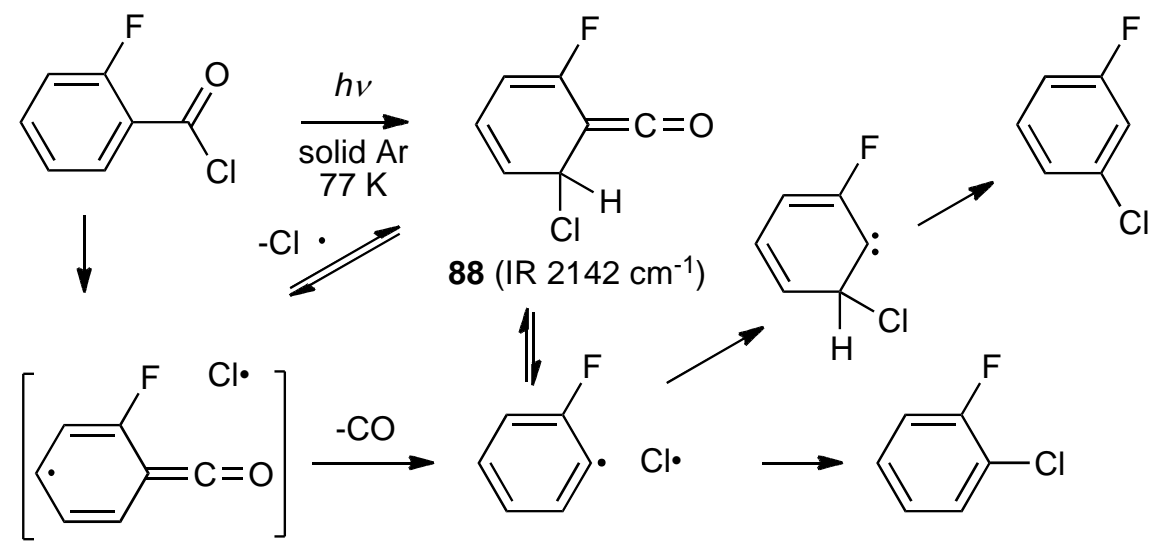

Scheme 41. Ketene formation by photolysis of 2-fluorobenzoyl chloride.

Reduction of stearic acid on $\mathrm{Ni} / \mathrm{ZrO}_{2}$ is interpreted as involving formation of the ketene 89 $\left(n-\mathrm{C}_{14} \mathrm{H}_{29} \mathrm{CH}=\mathrm{C}=\mathrm{O}\right)(\mathbf{8 9})$, as detected by strong IR absorption at $2050-2150 \mathrm{~cm}^{-1},{ }^{75}$ and formed by an elimination process followed by further hydrogenation to the alcohol and then decarbonylation (Figure 9). ${ }^{76}$

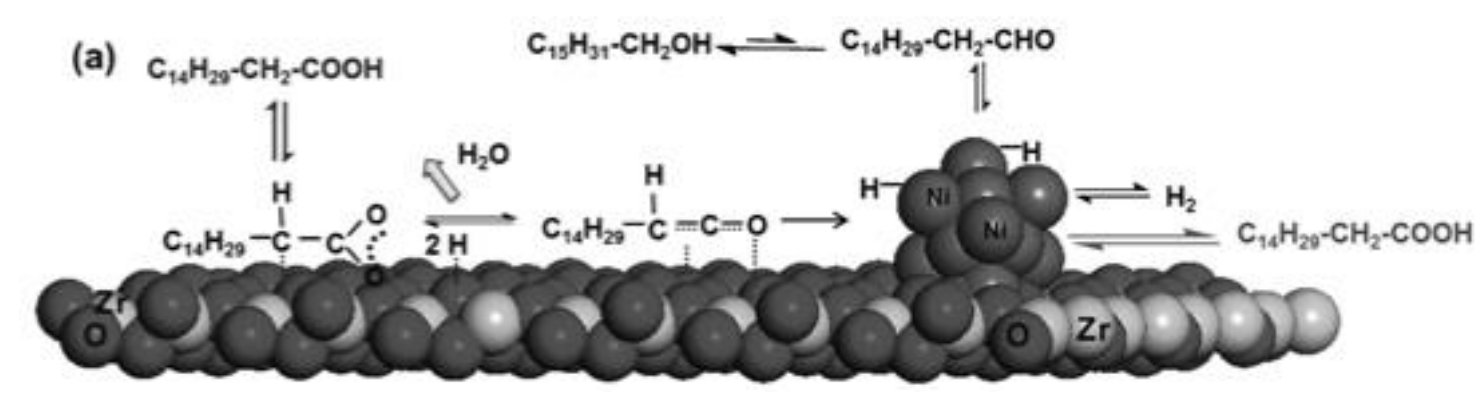

Figure 9. Ketene formation by carboxylic acid reduction (Reprinted with permission from the publisher ${ }^{76}$ ).

Studies of formation of gold ketenylidene species from carboxylic acids show that reactions of propionic and butyric acids on $\mathrm{Au} / \mathrm{TiO}_{2}$ proceed by dehydrogenation at the $\mathrm{C} 2-\mathrm{C} 3$ positions and oxidation to $\beta$-keto acids and decarboxylation with conversion into the gold ketenylidene intermediate $\mathrm{Au}_{2} \mathrm{C}=\mathrm{C}=\mathrm{O}(\mathbf{9 0})$, which also formed from acetic acid (Figure 10). ${ }^{77}$ 


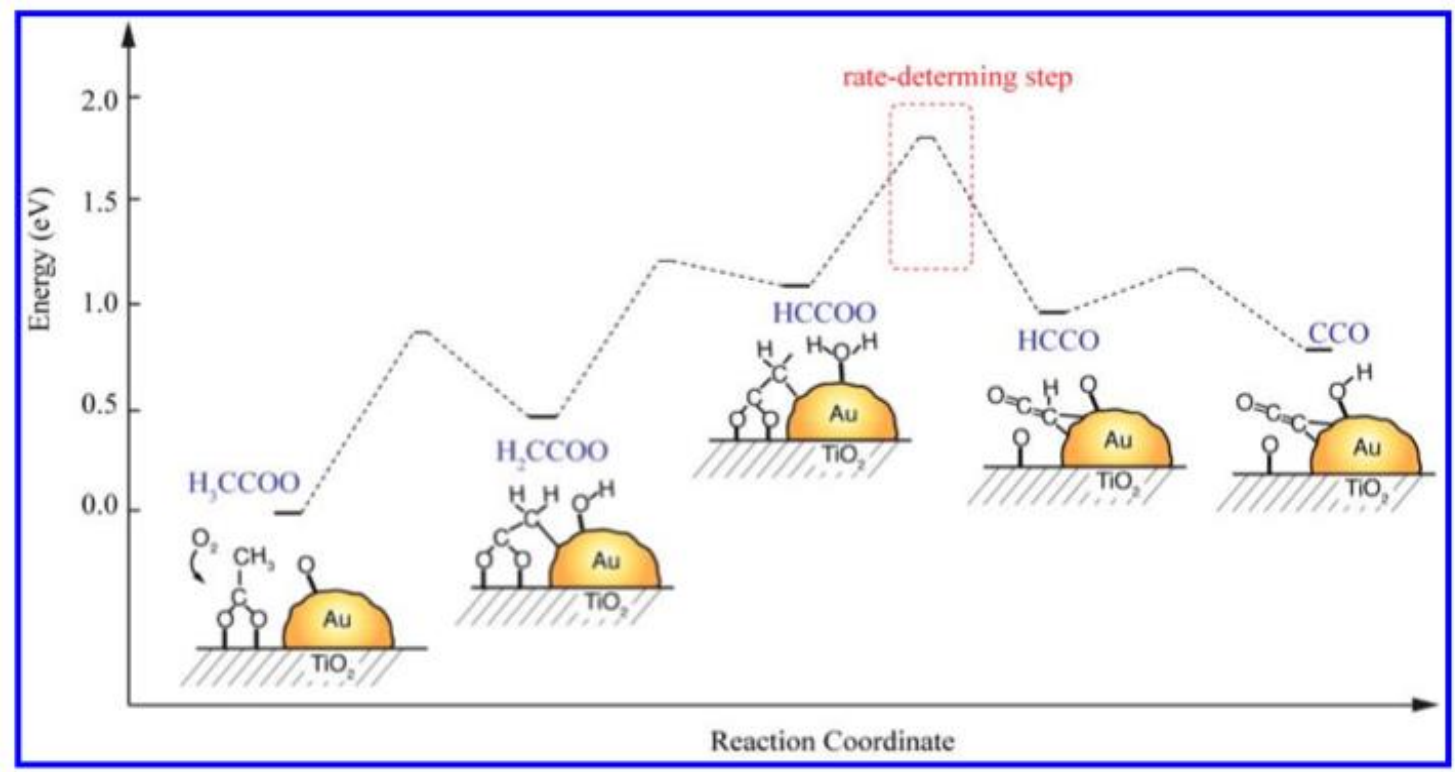

Figure 10. Gold ketenylidene formation for acetate oxidation on $\mathrm{Au} / \mathrm{TiO}_{2}$ (Reprinted with permission from the publisher ${ }^{77}$ ).

\subsection{Ketenes from dioxinones and ethynyl ethers}

Applications of ketenes generated by dioxinone thermolysis in synthesis have been reviewed; ${ }^{78}$ in the example of the synthesis of zearalenone $(\mathbf{9 3} \text {, Scheme } 42)^{79}$ the ketene intermediate 92 reacts with alcohol $\mathbf{9 1}$, followed by cyclization of the side chain after the esterification step.<smiles>C=CCCCC(=O)CCC[C@H](C)OC(=O)c1c(O)cc(O)cc1/C=C/C</smiles>

Scheme 42. Ketene generation with esterification and cyclization. 
Dioxinone thermolysis also provides a useful route to carboxy-substituted ketenes, as in the generation of the simple carboxyketene from Meldrum's acid, probably via its enolic form. Ketene 95 was trapped by alcohol 94 to give the product ester 96 (Scheme 43). ${ }^{80}$

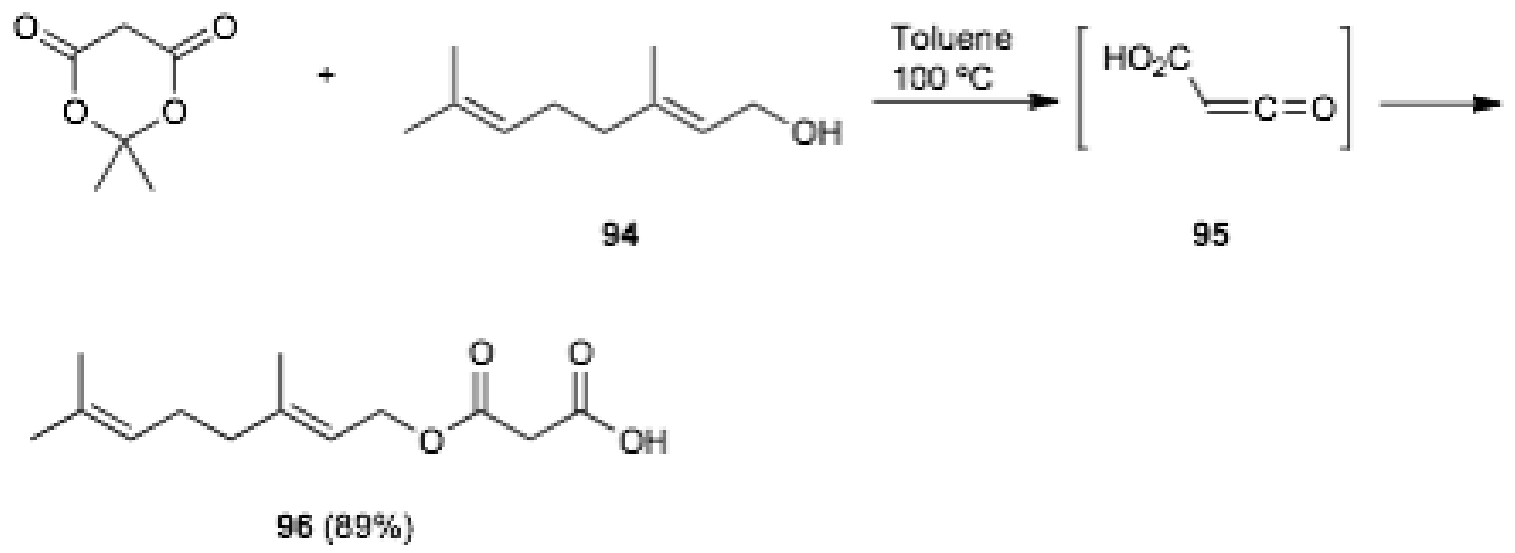

Scheme 43. Generation and capture of a carboxyketene.

The naphthodioxinone 97 upon reaction with three equivalents of phenyllithium in toluene at $-78^{\circ} \mathrm{C}$ followed by reflux gave the triarylmethanol 99 in a reaction interpreted as proceeding through formation of the ketene 98 (Scheme 44). ${ }^{81}$

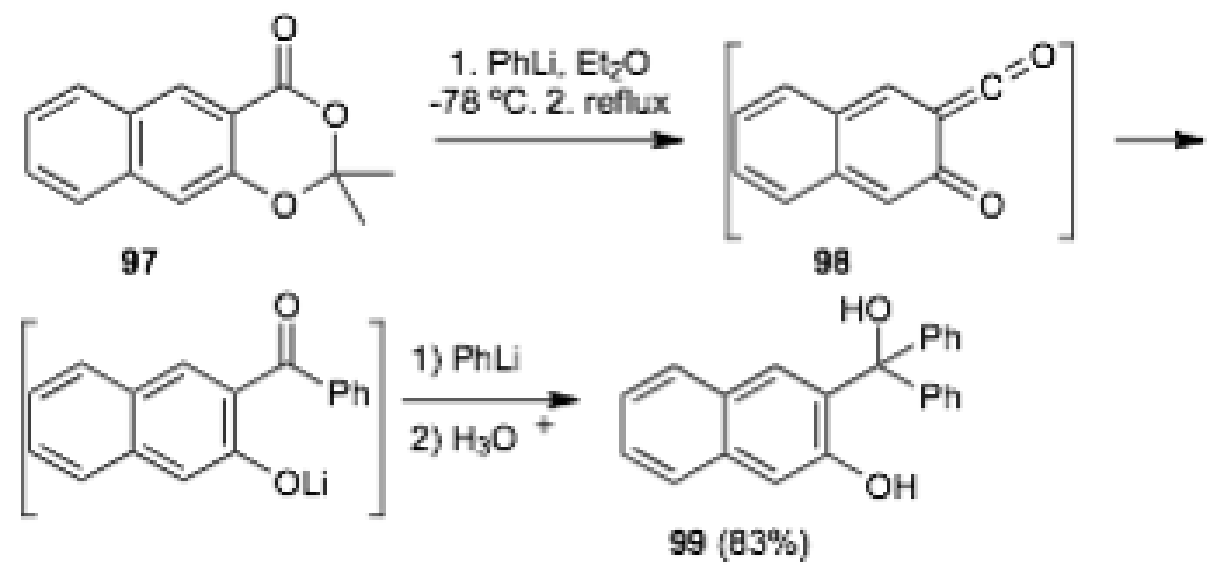

Scheme 44. Ketene generation with in situ capture by phenyllithium.

Meldrum's acid derivative $\mathbf{1 0 0}$ upon thermolysis with silver ion catalysis leads to $\gamma$-alkylidene butyrolactones $\mathbf{1 0 3}$ in reactions interpreted as involving formation of dioxinones 101 which form acylketene intermediates 102 (Scheme 45). ${ }^{82}$ The possibility of stereoselective complexation of the silver ion affecting the product stereochemistry was also considered. 

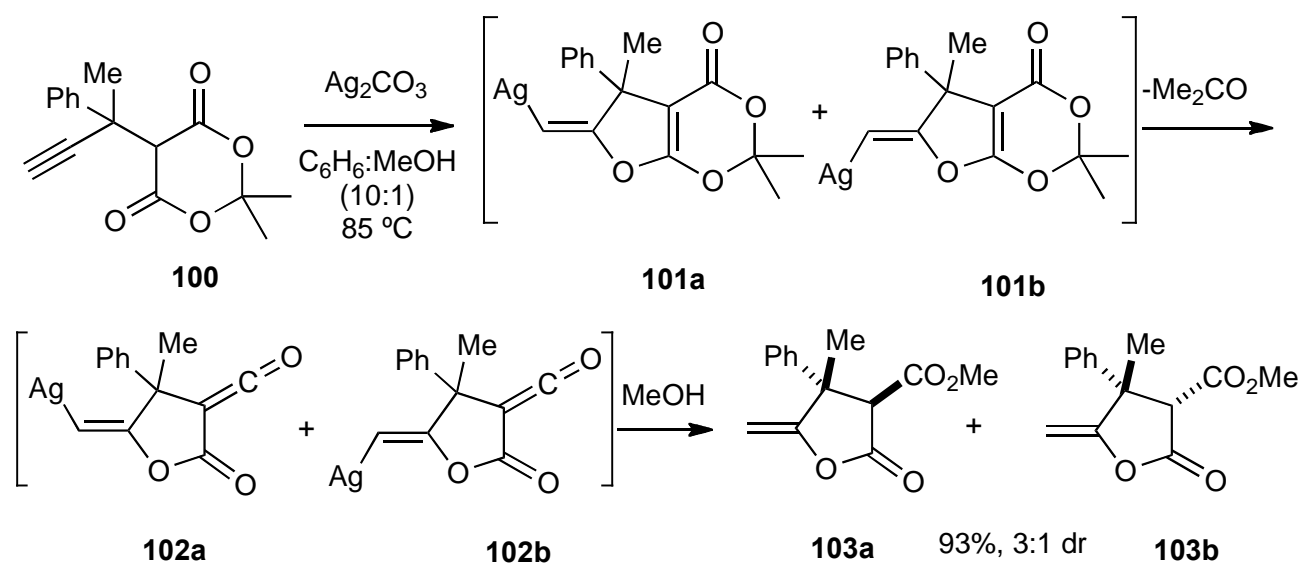

Scheme 45. Generation of acylketenes by thermolysis of Meldrum's acid derivatives with silver catalysis and esterification.

3-Pyridyl ketene $\mathbf{1 0 5}$ generated by thermolysis of intermediate tert-butyl arylethynyl ether 104, prepared from 3-iodopyridine by palladium-catalyzed coupling with tert-butyl ethynyl ether, reacts with morpholine in toluene forming the morpholide 106 (Scheme 46). ${ }^{83}$

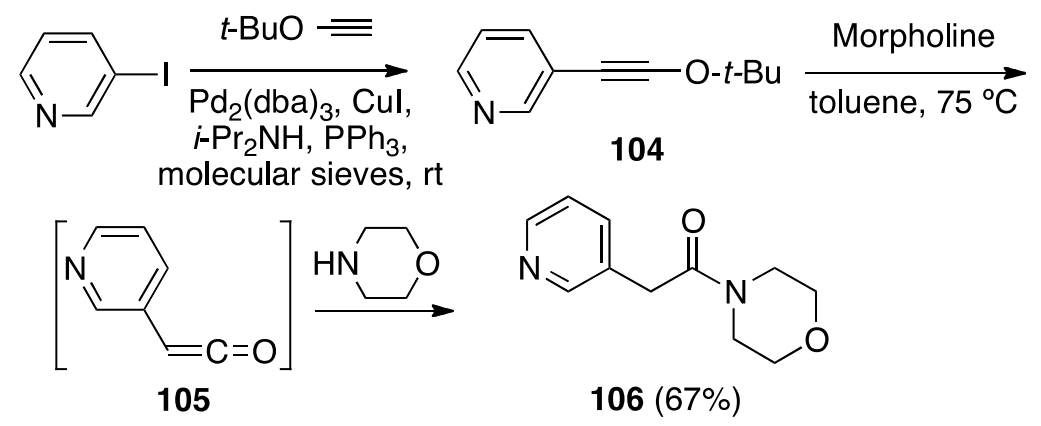

Scheme 46. Amide from ketene generated by thermolysis of pyridylethynyl tert-butoxy ethers.

Ketene 107 generated by alkoxyalkyne thermolysis under flow conditions reacts with amines or alcohols forming amides (Scheme 47) or esters, respectively. ${ }^{84}$

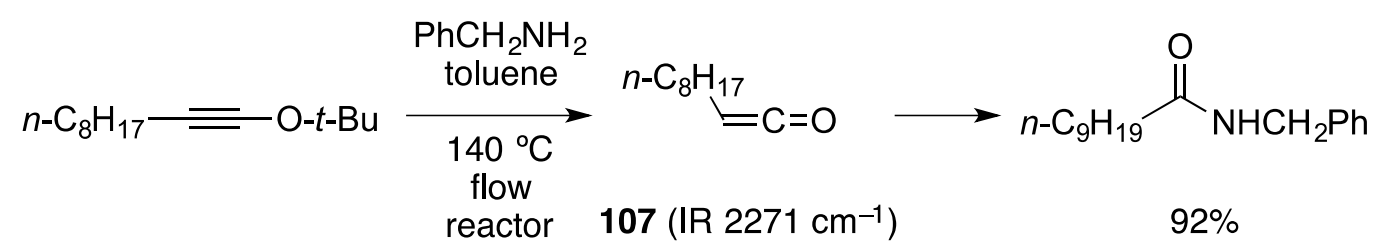

Scheme 47. Ketene generation and amination in a flow reactor. 


\subsection{Ketenes by other methods}

Cleavage of model $\beta$-lactams by mechanical activation using ultrasound was studied by both computational and experimental methods. ${ }^{85}$ Ultrasonication of $\beta$-lactam 108 in THF in the presence of isobutanol as a trapping agent resulted the formation of imine 110, as well as the ester 111 from trapping of ketene $\mathbf{1 0 9}$ (Scheme 48). ${ }^{85}$ GPC analysis indicated that $68 \%$ of the chains were cleaved.

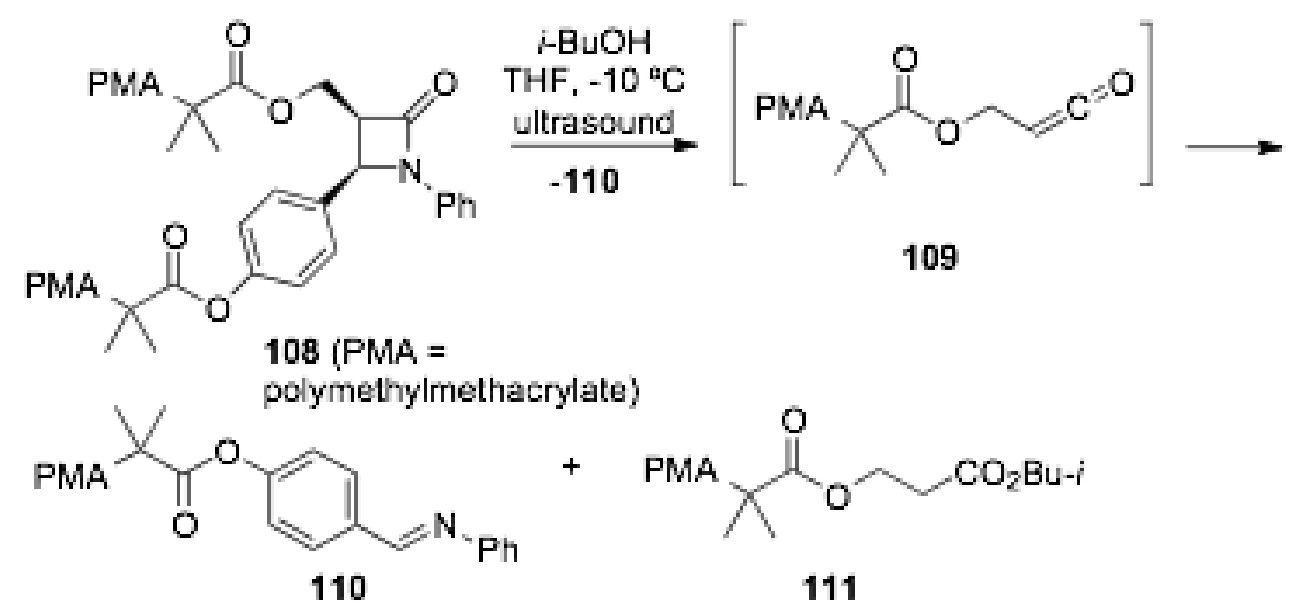

Scheme 48. Ketene generation by $\beta$-lactam cleavage and capture by alcohols.

Trifluoroacetylacetone $\mathbf{1 1 2}$ on a $\mathrm{ZnO}$ surface, as studied by Fourier-transform infrared spectroscopy (FT-IR), X-ray photoelectron spectroscopy (XPS), and density functional theory (DFT) computations, is proposed to form complexes of acetylketene $\left(\mathrm{CH}_{3} \mathrm{COCH}=\mathrm{C}=\mathrm{O}, 113\right)$ intermediates by loss of the $\mathrm{CF}_{3}$ group near $400 \mathrm{~K}$, as observed by IR absorption in the region near 2084 and $1990 \mathrm{~cm}^{-1}$ (Scheme 49). ${ }^{86}$

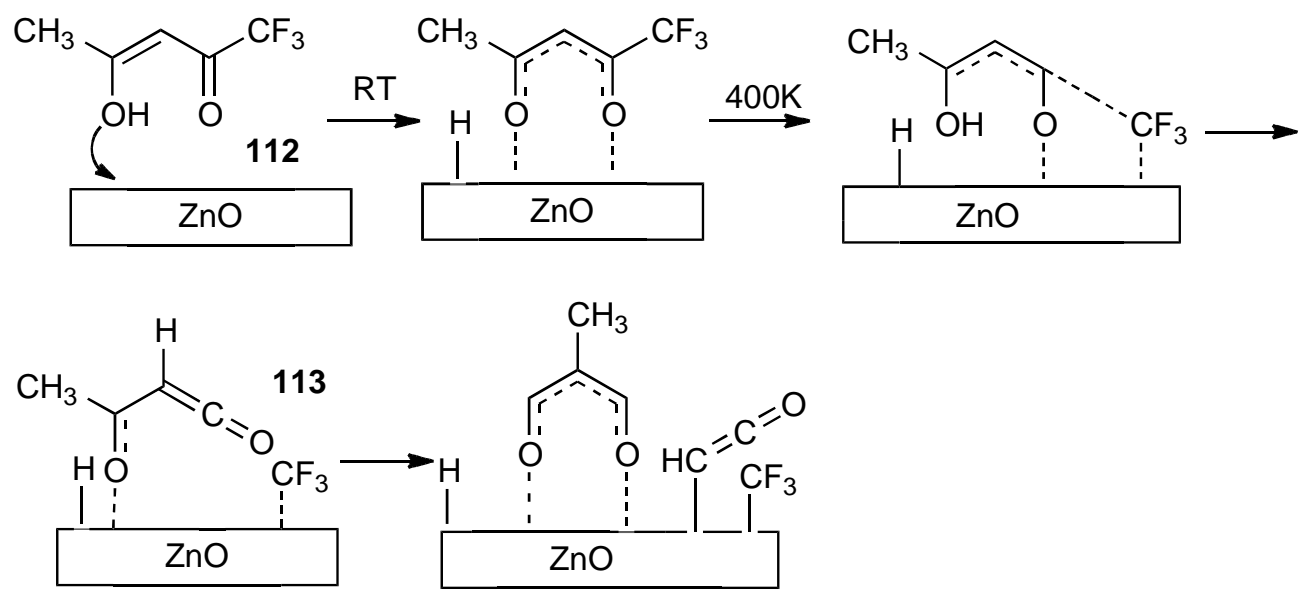

Scheme 49. Ketene formation on a $\mathrm{ZnO}$ surface. 
The gas-phase structure of ketene generated by pyrolysis of acetic anhydride has been determined, using a recently developed very high temperature inlet nozzle system. ${ }^{87}$

Analysis of available telescopic data for the solar-type protostar IRAS16293-2422 led to the identification of the parent ketene formed in space, together with other small organic molecules. $^{88}$

\section{Cycloaddition Reactions of Ketenes}

\subsection{Ketene dimers, preparations and applications}

Asymmetric ketene dimers including 114 are prepared by a process where a more reactive ketene is generated in the presence of a less reactive ketene in the presence of a chiral catalyst (Scheme 50). ${ }^{89}$ The catalyst adds to the more reactive ketene and the resulting reactive enolate reacts with the less reactive ketene to form the unsymmetrical dimer. By this process methylketene formed by dehydrochlorination in methylene chloride in the presence of the chiral catalyst TMS-quinine (TMSQ) reacts with dimethylketene forming the mixed dimer 114 (Scheme 50). ${ }^{89}$ The dimer is converted by catalytic hydrogenolysis with regioselective ring opening to form 115 (Scheme 50). ${ }^{90}$ See also Scheme 66
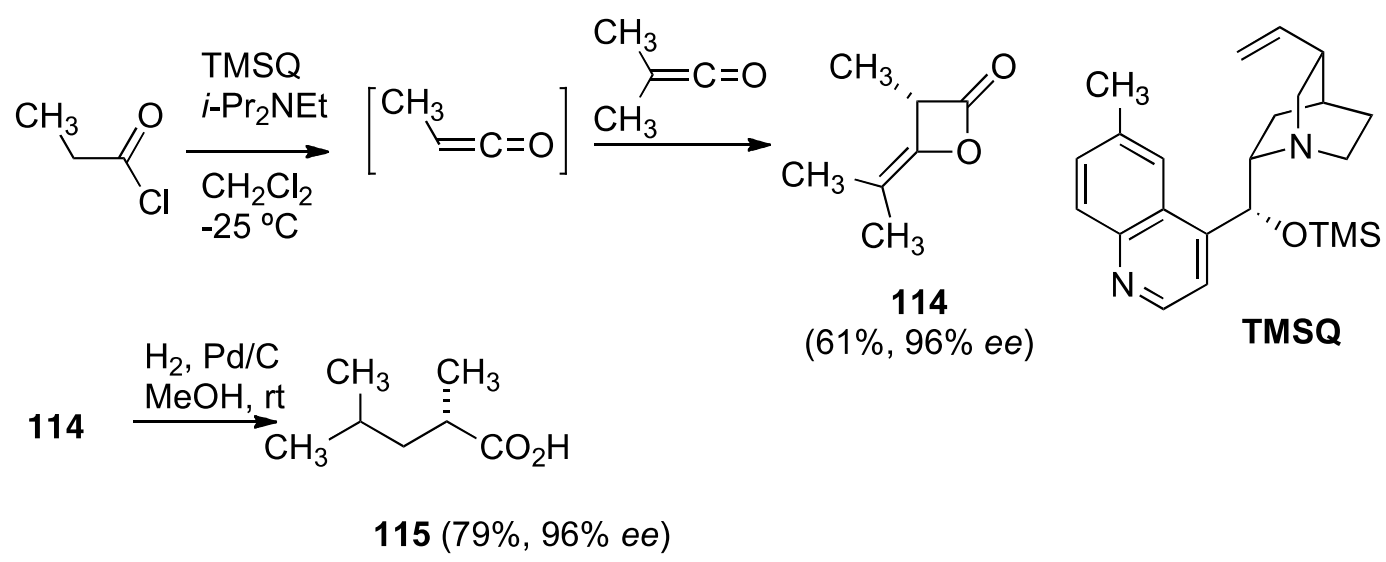

Scheme 50. Stereoselective formation of mixed ketene dimer and subsequent hydrogenolysis.

\section{2 [2+2] Cycloaddition reactions with carbon-carbon double and triple bonds}

Limited amounts of a ketene such as $\mathbf{8 6}$ can react with a mixture of $Z$ and $E$ olefins $\mathbf{1 1 6}$ resulting in kinetic resolution by [2+2] cycloaddition, with isolation of pure unreacted $E$ alkenes, as well as isolation of pure cis-cyclobutanone 117 (Scheme 51; dechlorination by the zinc-copper couple occurs). This result is attributed to the much greater reactivity of the $Z$-alkenes, which permits more facile reaction from the unsubstituted side by the ketene. ${ }^{91}$ 


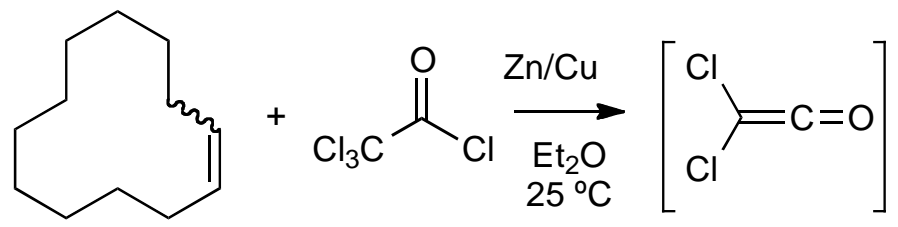

$116(Z / E=71: 29)$

86

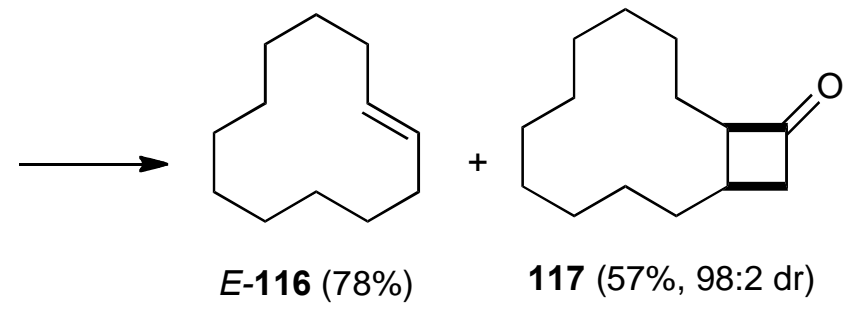

Scheme 51. Kinetic resolution of $E / Z$ alkenes by ketene [2+2] cycloaddition.

In a further application of this methodology reaction of alkenes 118 as a $Z / E$ mixture of isomers with diphenylketene gave the pure $E$-allylic ether $(E)-\mathbf{1 1 8}$, isolated in $50 \%$ yield. (Scheme 52). ${ }^{91}$

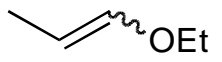

$118(E / Z=37 / 63)$

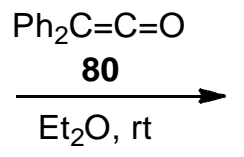<smiles>CC=COCC</smiles>

E-118 ( pure $E, 81 \%$ by NMR, $50 \%$ isolated)

Scheme 52. Kinetic resolution of $E / Z$ alkenes by selective reaction of $Z$-isomers with ketenes.

In another example, reaction of 118 with 0.15 equivalents of in situ generated dichloroketene (86) followed by reduction with lithium aluminum hydride gave the cyclobutanol 119 (Scheme 53). ${ }^{91}$

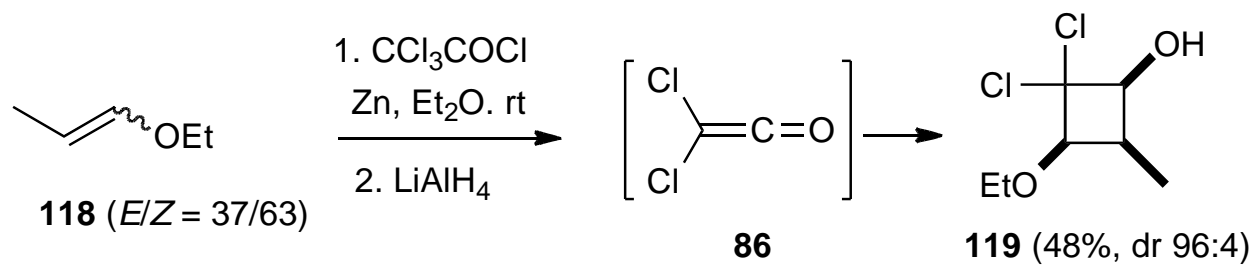

Scheme 53. Selective reaction of $E$-isomers with ketenes.

Vinylketene 122 generated by dehydrochlorination of $\mathbf{1 2 0}$ reacts in a [2+2] cycloaddition with alkene $\mathbf{1 2 1}$ with catalysis by trimethylaluminum forming the cyclobutenone $\mathbf{1 2 3}$ (Scheme 54), which was used in the synthesis of gracilioether F. ${ }^{92}$ The stereoselectivity of the 
cycloaddition was $>20: 1$, and the stereochemistry of the substituent at C7 was not relevant in the remaining synthesis.<smiles>COC(=O)C/C=C(\O)c1ccccc1</smiles>

120

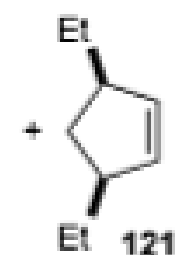

121

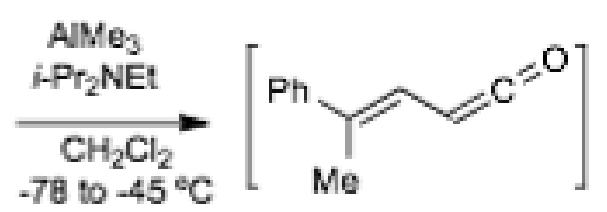

122

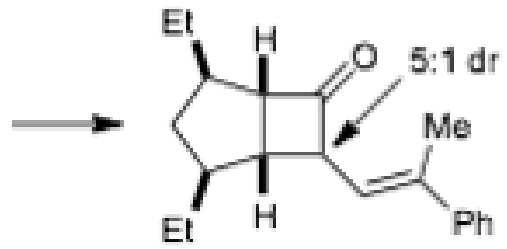

$12365 \%(>20: 1 \mathrm{dr})$

Scheme 54. Stereoselective [2+2] cycloaddition to alkenes.

Ketene 125, generated by dehydration of carboxylic acid 124, in an intramolecular [2+2] cycloaddition forms cyclobutanone 126 (Scheme 55), and this was used as a precursor of ophiodilactones. $^{93}$

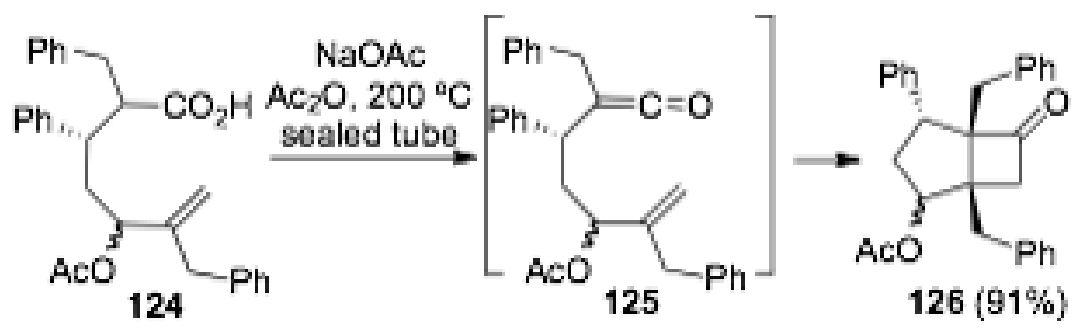

Scheme 55. Ketene generation and intramolecular [2+2] alkene cycloaddition.

A computational study of [2+2] cycloaddition of benzylphenylketene (127) with cyclopentadiene shows a preference for formation of $\mathbf{1 2 9}$ in an uncatalyzed concerted reaction through transition state 128 (Scheme 56). ${ }^{94}$ The computations suggest that the reaction promoted by Lewis acid catalysis with ethylaluminum dichloride $(\mathrm{EtAlCl})$ proceeds in two steps with formation of an intermediate $\mathbf{1 3 0}$ which closes to form the stereoisomeric product $\mathbf{1 3 1}$ (Scheme 56). ${ }^{94}$ 


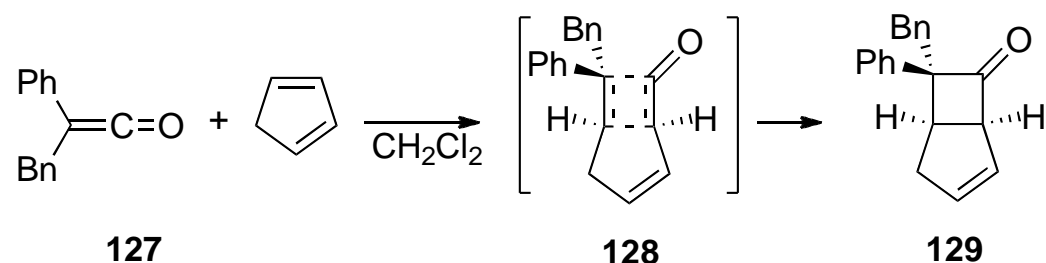

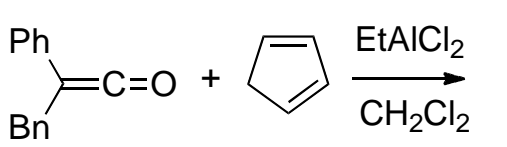

127

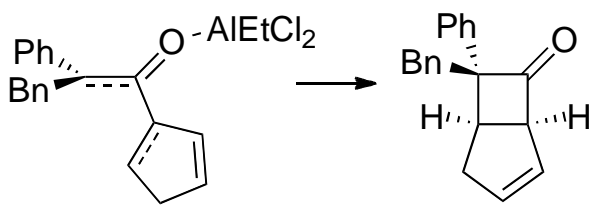

130

131

Scheme 56. Computed stereoselectivity in uncatalyzed and catalyzed ketene [2+2] cycloaddition with alkenes.

Computational analysis was also used to interpret the stereoselective Lewis acid catalyzed $[2+2]$ cycloaddition of phenylethylketene (132) with arylalkenes (Scheme 57). ${ }^{95}$

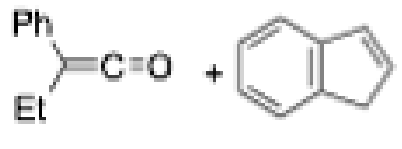

132

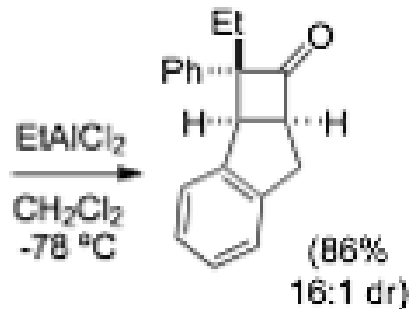

$16: 1 \mathrm{dr})$

Scheme 57. Stereoselectivity in ketene/alkene [2+2] cycloaddition.

Ketene generation from terminal alkynes using ruthenium catalyzed oxidation with use of the phosphine $\mathbf{1 3 3}$ as a co-catalyst gives intramolecular cyclobutanone (135) formation (Scheme 58). ${ }^{95}$ Similar ketene generation in the presence of imines leads to $\beta$-lactams. ${ }^{96}$ 


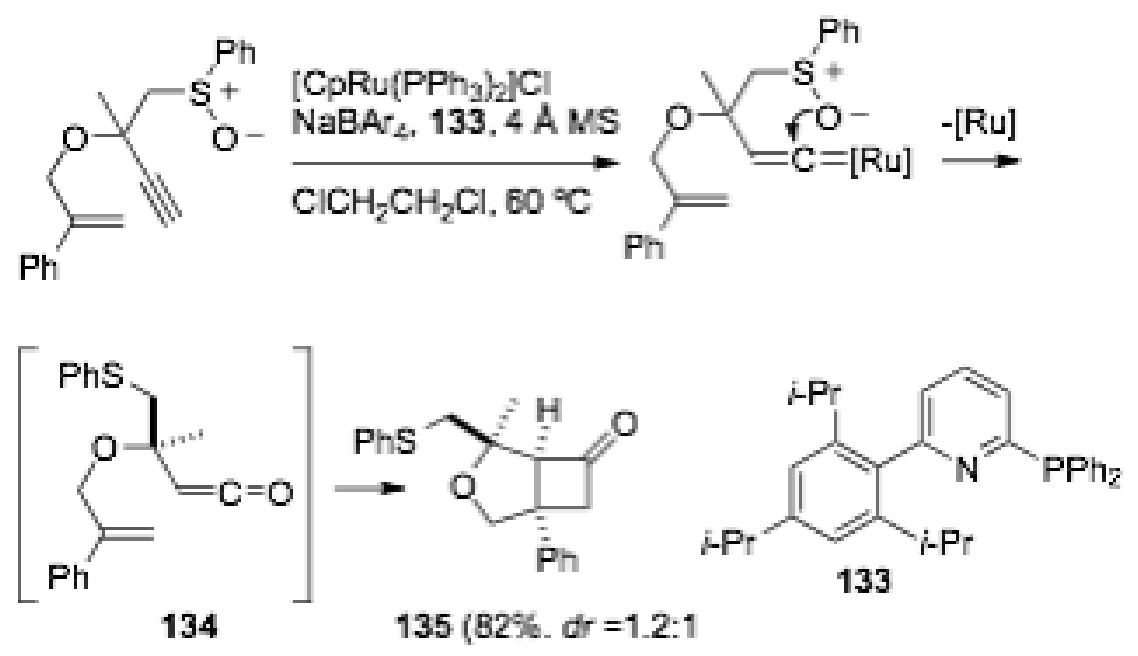

Scheme 58. Ruthenium-catalyzed ketene generation and stereoselective cycloaddition.

Trimethylene- and tetramethylene-ketenes $(\mathbf{1 3 5}, \mathbf{1 3 7})$ generated by acyl chloride dehydrohalogenations give [2+2] cycloaddition reactions with dihydrofuran and dihydropyran forming spirocyclic cyclobutanones 136, 138 (Scheme 59). ${ }^{97}$

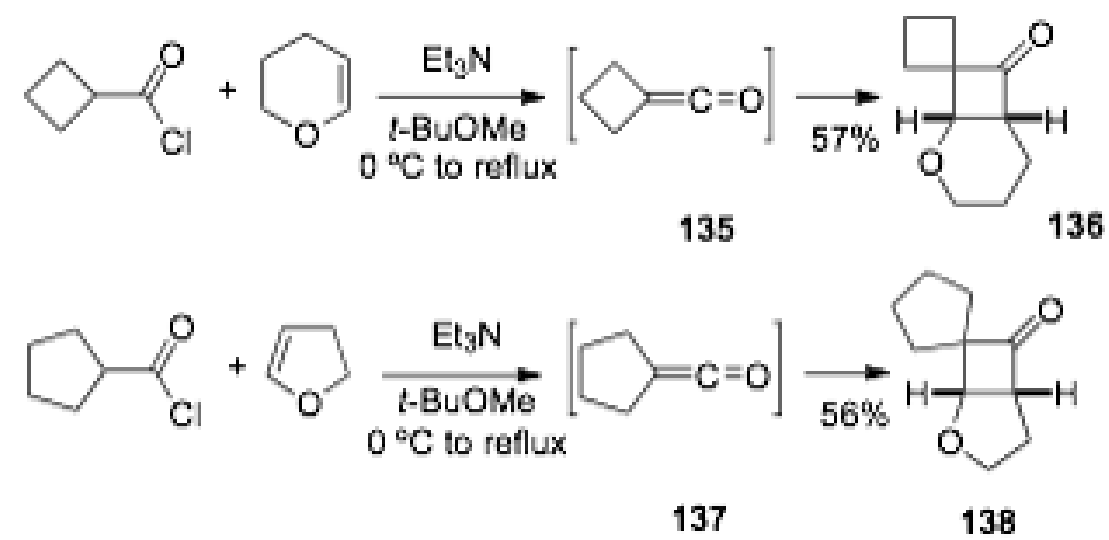

Scheme 59. Ketene [2+2] cycloaddition with cyclic vinyl ethers forming spirocyclic cyclobutanones.

Generation of dienylketene $\mathbf{1 3 9}$ by dehydrochlorination of the acyl chloride prepared using the Ghosez reagent followed by intramolecular [2+2] ketene-alkene cycloaddition forms the ring-fused cyclobutanone 140, used in the synthesis of strigolactones (Scheme 60). ${ }^{98}$ 


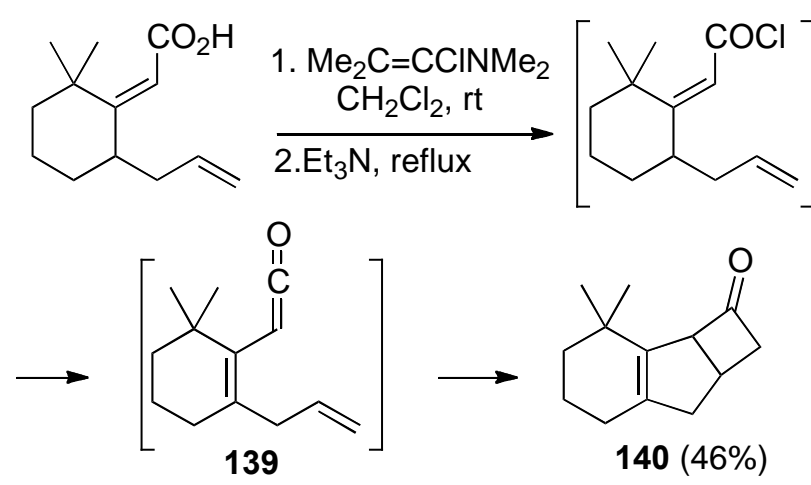

Scheme 60. Intramolecular dienylketene cyclization.

Dimethylketene (141) reacts with 1,5-hexadiene by [2+2] cycloaddition forming cyclobutanone 142, used in the synthesis of junionone (Scheme 61). ${ }^{99}$

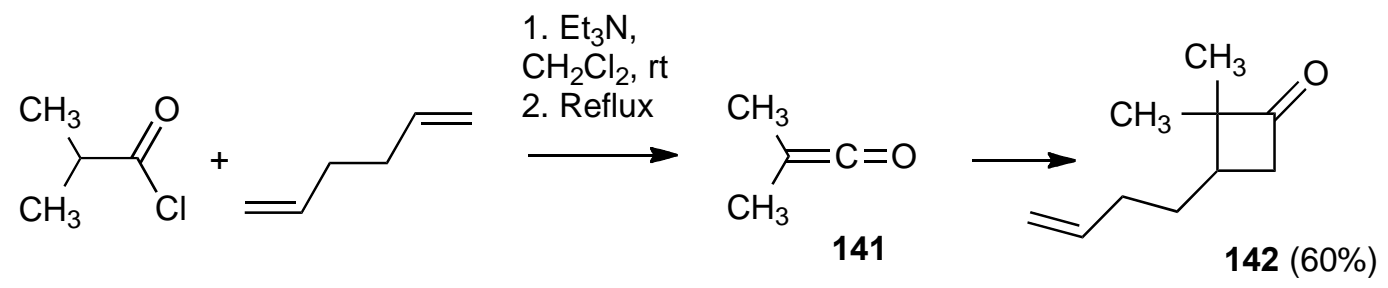

Scheme 61. Ketene alkene cyclization forming a junionone precursor.

Vinylketene 144 generated by cyclobutenone thermolysis undergoes [4+2] cycloaddition with ynamide 143 forming the phenol 145 (Scheme 62). ${ }^{100}$ The reactions eventually led to a versatile synthesis of polysubstituted quinolines.
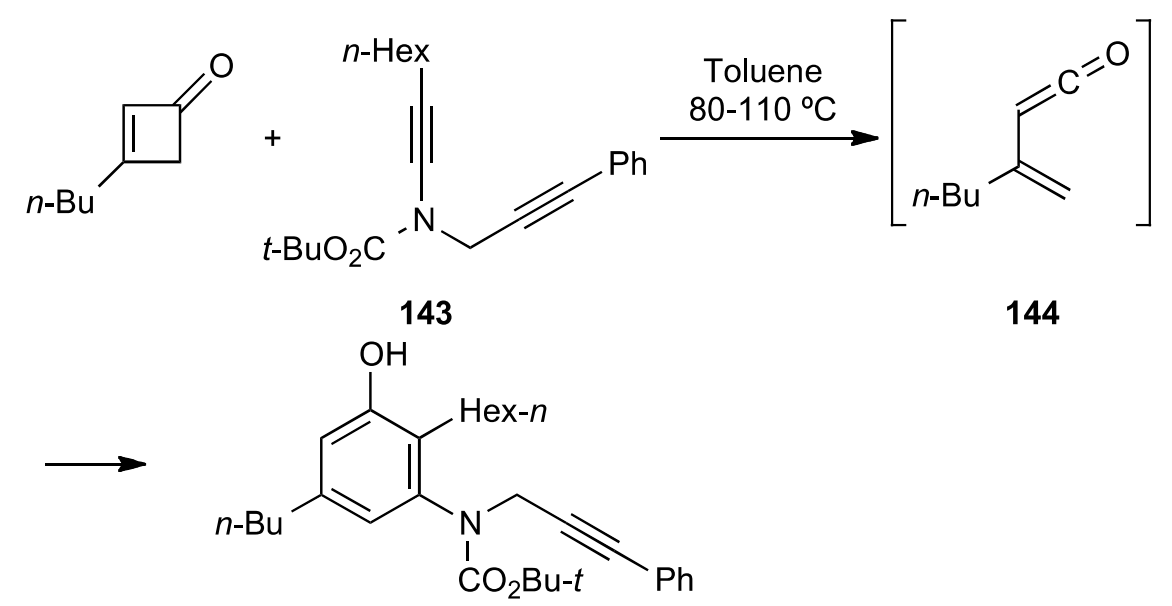

$145(86-89 \%)$

Scheme 62. Vinylketene/alkyne [4+2] cycloaddition for phenol synthesis. 
Net [2+4] cycloadditions of phenylethylketene 132 with alkynyl ethers (e.g. Scheme 63) have been reviewed. ${ }^{101}$

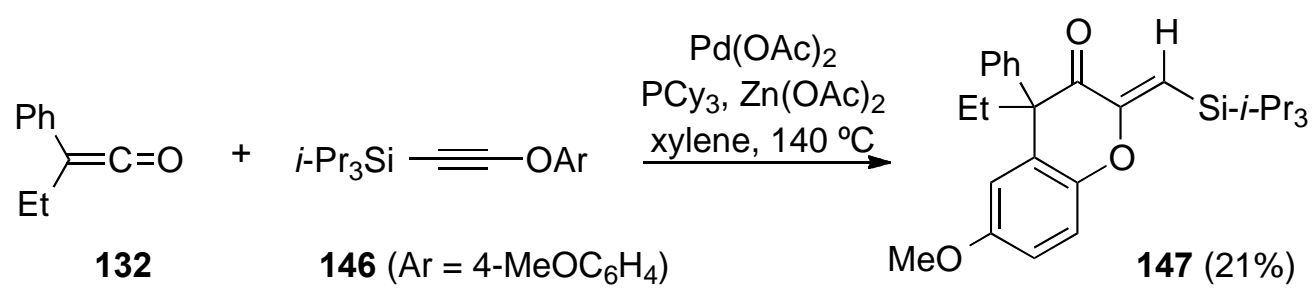

Scheme 63. Net ketene alkynyl ether [4+2] cycloaddition.

\section{3. $[2+2]$ Cycloaddition reactions with carbon-oxygen bonds}

Dimethylketene (141) reacts with aldehyde 148 forming the $\beta$-lactone 149 (Scheme 64), which was used in a highly diastereoselective synthesis of (+)-peloruside A. ${ }^{102}$

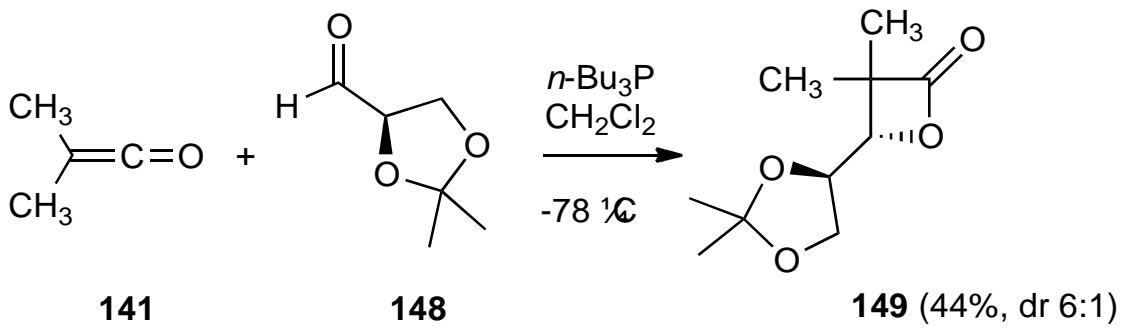

Scheme 64. Ketene [2+2] cycloaddition with an aldehyde in diastereoselective synthesis.

Stereoselective [2+2] cycloadditions of ketenes with chiral aldehydes catalyzed by tri- $n$ butylphosphine give $\beta$-lactones with diasteroselectivity up to 4:1 (Scheme 65). ${ }^{103}$

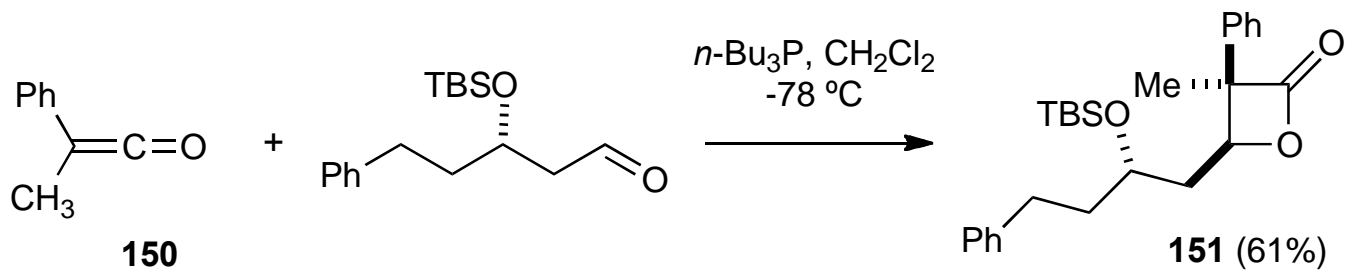

Scheme 65. Stereoselective ketene cycloaddition with an aldehyde.

Polymer supported cinchona alkaloid P10 serves as a catalyst for dimerization of ketenes including 152, with subsequent amination of the dimer forming 153 (Scheme 66). ${ }^{104}$ 

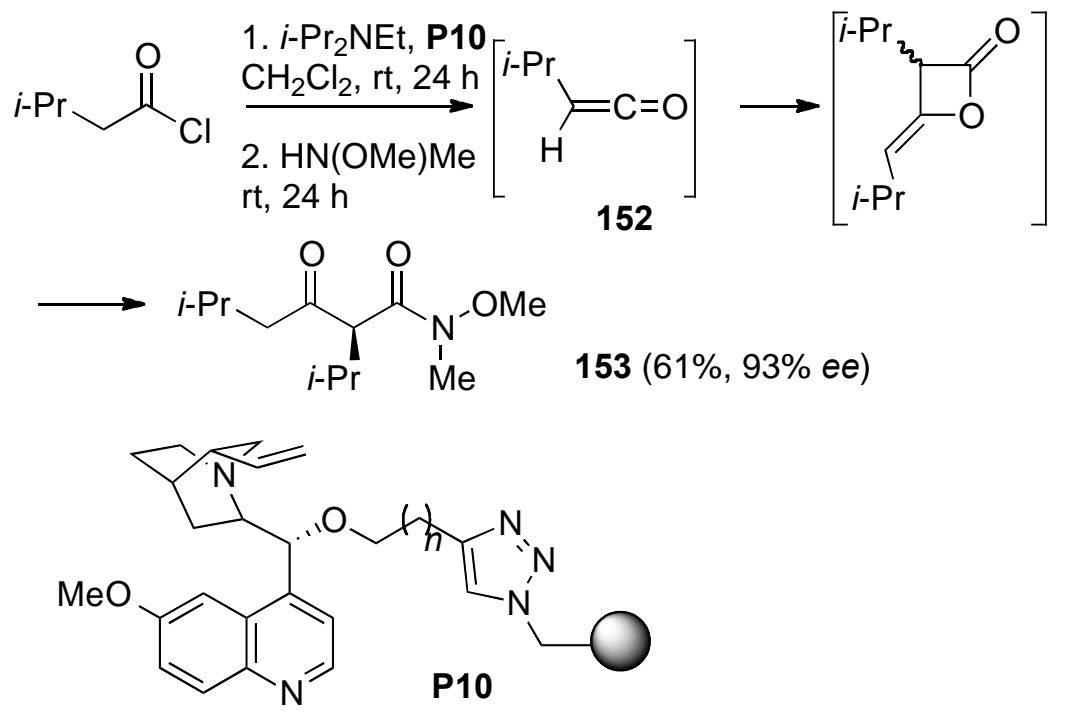

Scheme 66. Stereoselective ketene dimerization.

Phenylethylketene (132) reacts with trichloroacetaldehyde with catalysis by $N$-heterocyclic carbene 155 generated in situ from the salt 154 with selective formation of $\beta$-lactones 156), while $\mathbf{1 5 7}$ forms the $\alpha$-chloro ester $\mathbf{1 5 8}$ (Scheme 67). ${ }^{105}$ The chlorination pathway is favored by 2-substitution on the aryl group or branching in the alkyl substituent.

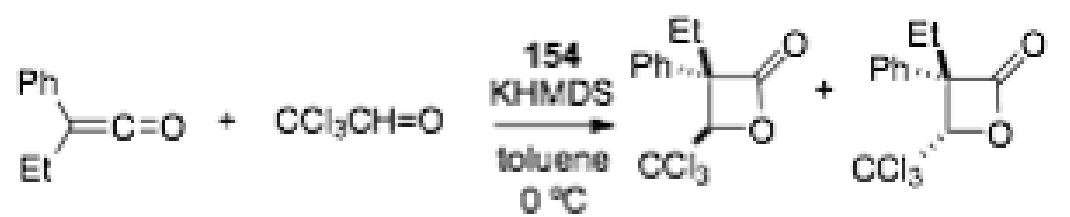

132

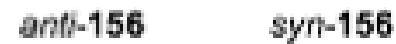

$54 \%, 94 \%$ ee $22 \%, 92 \%$ ee

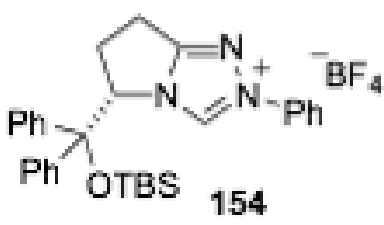<smiles></smiles>

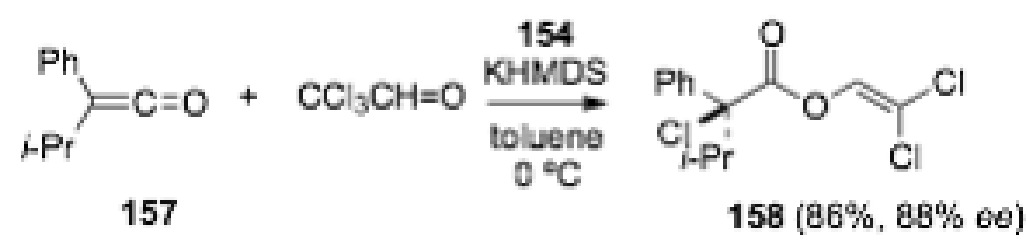

Scheme 67. Ketene substituent effects on reactivity with chloral using a chiral catalyst.

4.4. [2+2] Cycloaddition reactions with carbon-nitrogen bonds. $\beta$-Lactam formation by ketene / imine [2+2] cycloaddition is one of the most characteristic and widely-studied ketene reactions, and is the subject of recent reviews..$^{106,107}$ 
Phenylketene (159) generated from benzaldehyde $N$-tosylhydrazone salt by carbonylation using the rhodium catalyst $\mathbf{1 6 1}$ reacted with imines to give stereoselective formation of the $\beta$ lactam 160 (Scheme 68). ${ }^{108}$

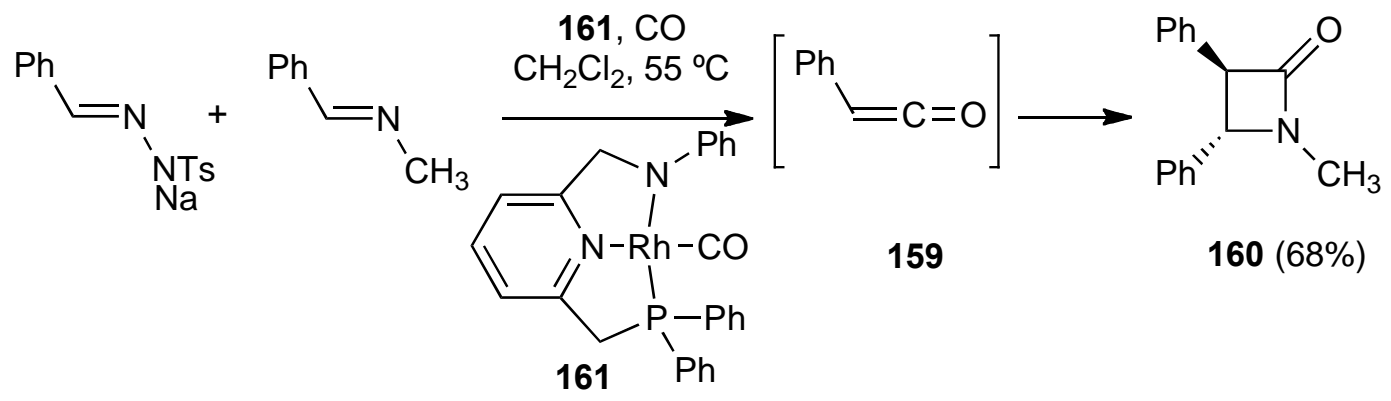

Scheme 68. Ketene generation by $N$-tosylhydrazone carbonylation with imine cycloaddition.

Phenylethylketene (132) undergoes stereoselective [2+2] cycloaddition with imine 162 forming $\beta$-lactam 163 with catalysis by the $N$-heterocyclic carbene generated from 164 (Scheme 69). ${ }^{1091}$

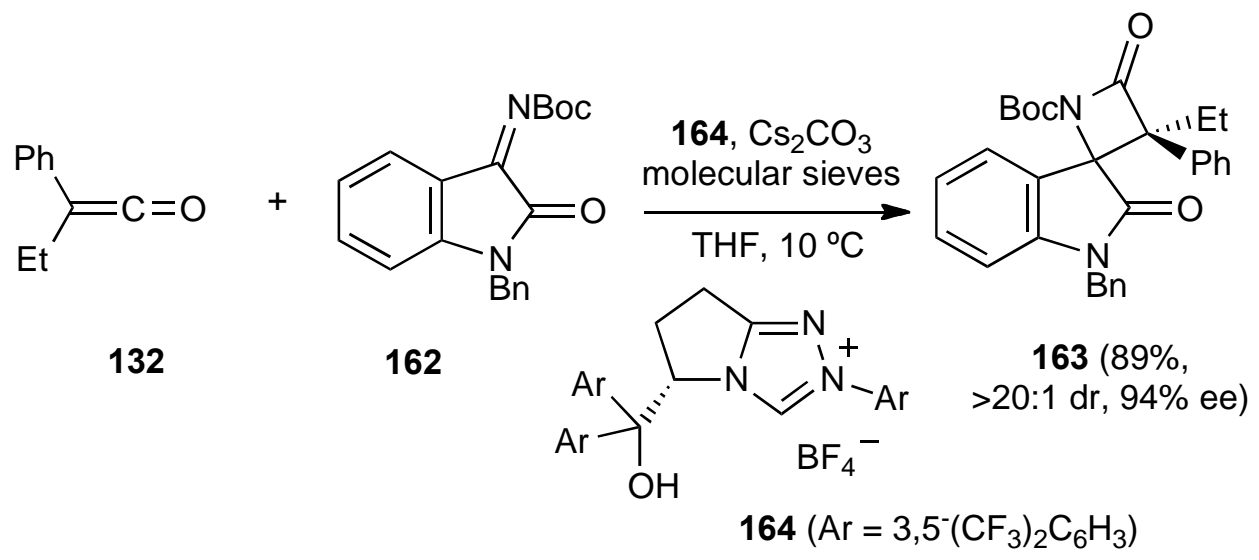

Scheme 69. Spiro $\beta$-lactam formation by ketene-imine [2+2] cycloaddition.

Thermolysis of propynyl sulfoxide 165 in the presence of imine 166 and a ruthenium catalyst 167 and ligand 133 is proposed to give ketene 168 which reacts with the imine by [2+2] cycloaddition forming $\beta$-lactam 169, together with small amounts of thioester 170, suggested to result from ketene rearrangement (Scheme 70). ${ }^{110}$ In the absence of imines thioesters are the major products.

Ketenes including 171 generated by zinc debromination of $\alpha$-bromoacyl bromide under flow conditions were observed by their characteristic IR absorption, and in the presence of imines they efficiently formed $\beta$-lactams (Scheme 71). ${ }^{111}$ 


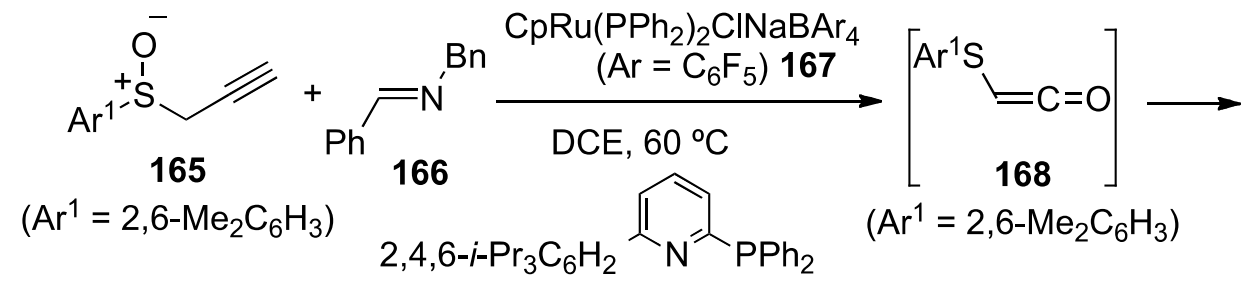

133

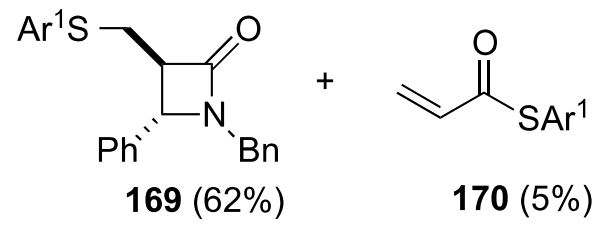

Scheme 70. Ketene generation by propynyl sulfoxide thermolysis and [2+2] imine cycloaddition with $\beta$-lactam formation.

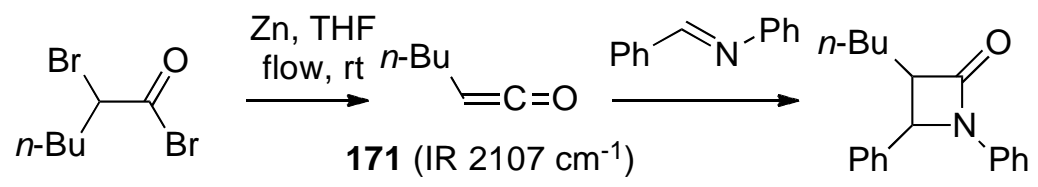

$(77 \%$, cis/trans $=1: 7.8)$

Scheme 71. Ketene-imine [2+2] cycloaddition with $\beta$-lactam formation in a flow system.

Ketenes generated from carboxylic acids using dimethyl sulfoxide and acetic anhydride give $\beta$-lactams by [2+2] cycloaddition with imines (Scheme 72). ${ }^{112}$

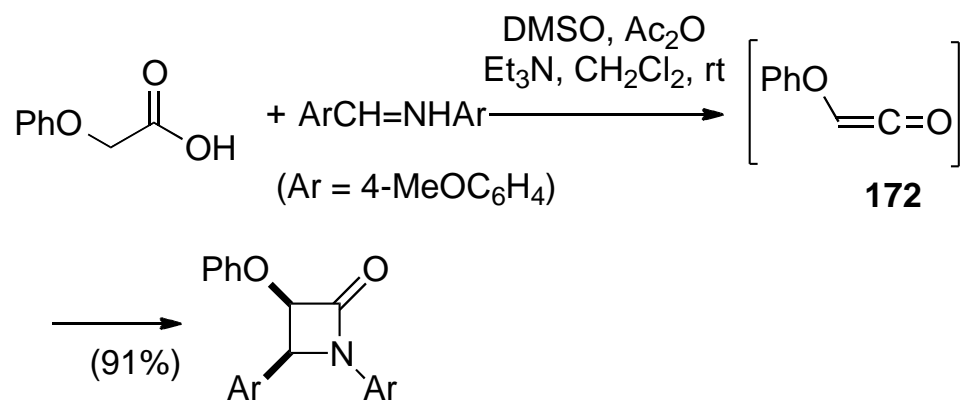

Scheme 72. Ketene generation by carboxylic dehydration, and cycloaddition with imines.

Dichloroketene (86) generated by thermal dehydrochlorination reacts with the $2 \mathrm{H}$ indazolo[2,1- $b]$ phthalazinetrione 173 forming the corresponding phthalazine substituted $\beta$ lactam 174 (Scheme 73), evaluated for its inhibitory effect on the activity of purified human carbonic anhydrase. ${ }^{113}$ 


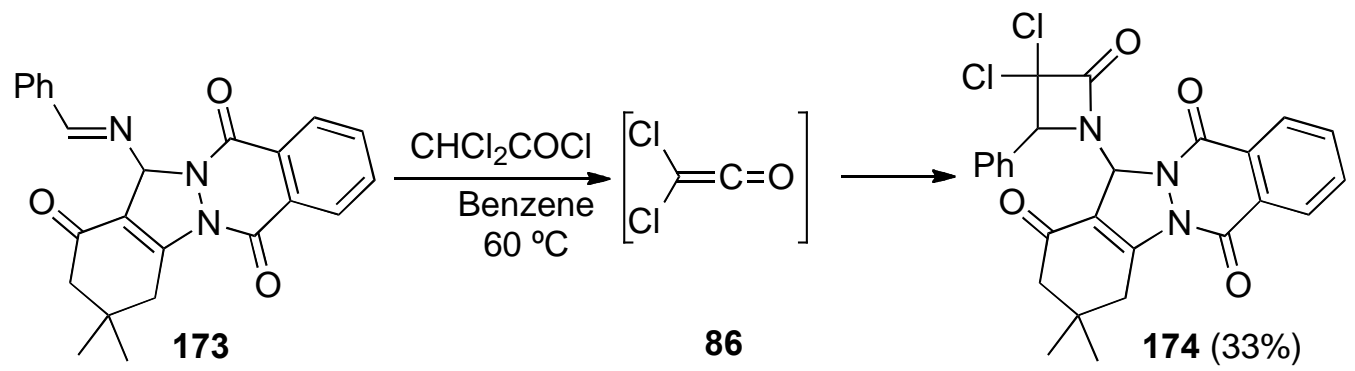

Scheme 73. Dichloroketene [2+2] indazolo-phthalazine cycloaddition.

Aryloxyketenes including 172, generated by dehydrochlorination, give [2+2] cycloaddition with 4-nitroaryl substituted imines forming $\beta$-lactams 175 (Scheme 74), and then the aryl nitro groups are converted into $\mathrm{NHCOCH}=\mathrm{CH}_{2}$ groups and the resulting vinyl monomers are copolymerized giving nanopolymers containing $\beta$-lactam groups. ${ }^{114}$

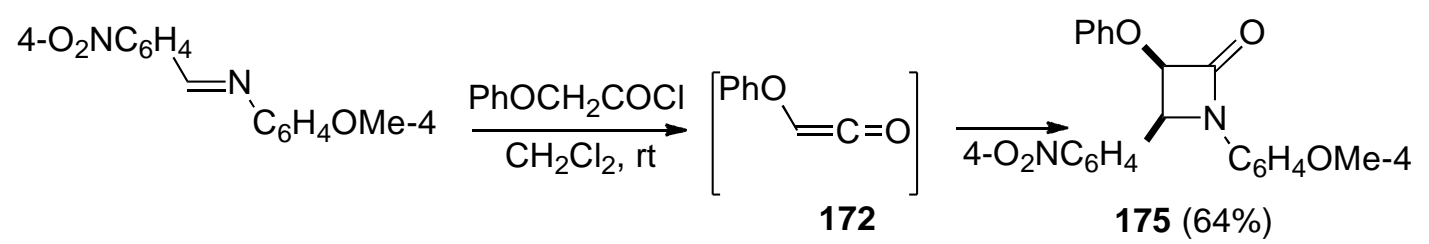

Scheme 74. Phenoxyketene [2+2] imine cycloaddition.

cis-3,4-Disubstituted $\beta$-lactams 178 were prepared by [2+2] cycloaddition of chiral imines 176 with chiral ketene 177, and were evaluated for their antimalarial activity (Scheme 75). ${ }^{115}$

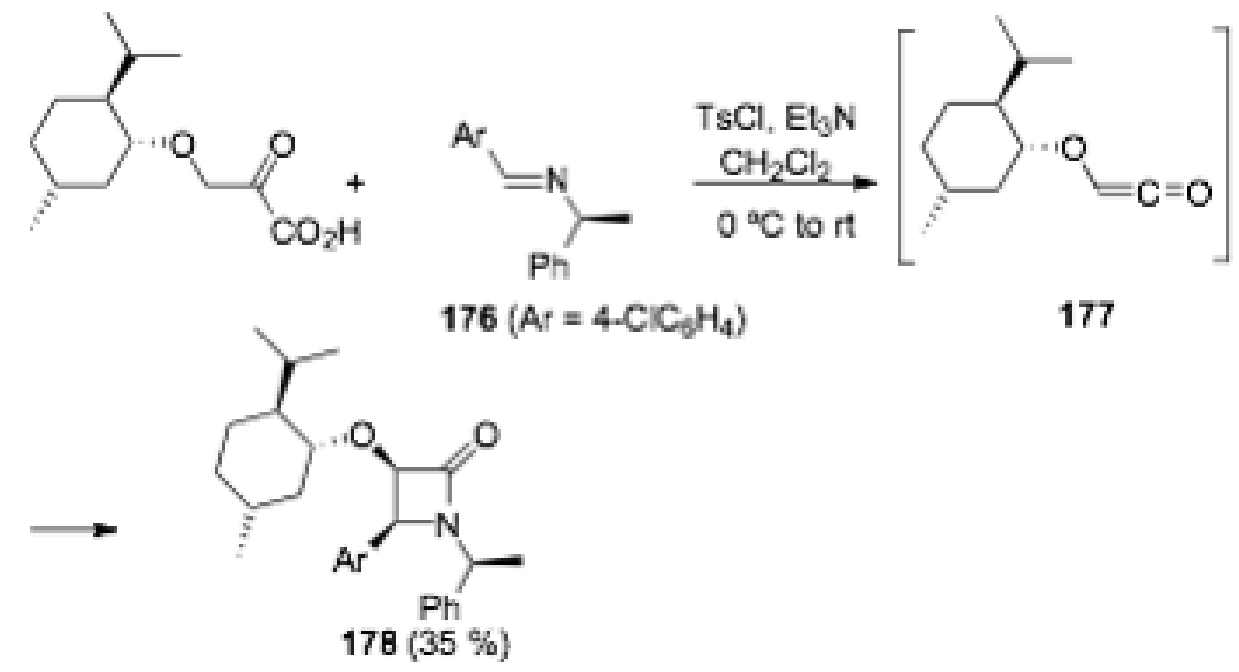

Scheme 75. Chiral ketene/chiral imine [2+2] cycloaddition. 
Ketene 179 generated by net dehydration of a carboxylic acid by reaction with tosyl chloride and triethylamine gives [2+2] cycloaddition with imines, forming $\beta$-lactams (Scheme 76). ${ }^{116}$

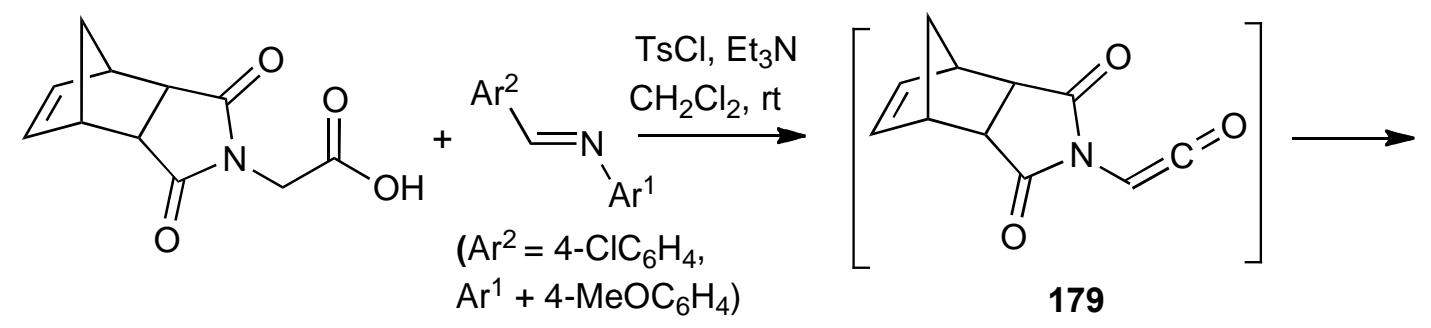<smiles>O=C1C2C3C=CC(C3)[C@@H]2C(=O)N1[C@H]1C(=O)N([Al])[C@@H]1[TeH]</smiles>

Scheme 76. Selective [2+2] ketene cycloaddition with diaryl imines.

Phenoxyketene (172) generated by dehydrochlorination of phenoxyacetyl chloride (181) reacts with imines such as $\mathbf{1 8 2}$ substituted by polycyclic aryl groups forming the corresponding $\beta$-lactams (Scheme 77). ${ }^{117}$

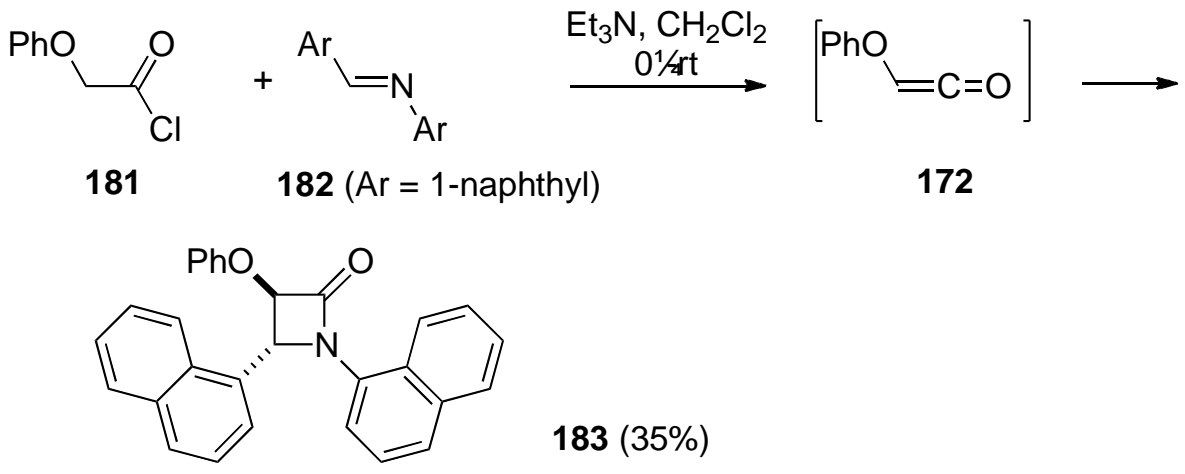

Scheme 77. Selective [2+2] ketene cycloaddition with di(polycycloaryl) imines.

Ketene 184, generated by acyl chloride dehydrochlorination, reacts by [2+2] cycloaddition with imines with selective formation of $\beta$-lactams such as $\mathbf{1 8 5}$, as single stereoisomers (Scheme 78). ${ }^{118}$ 


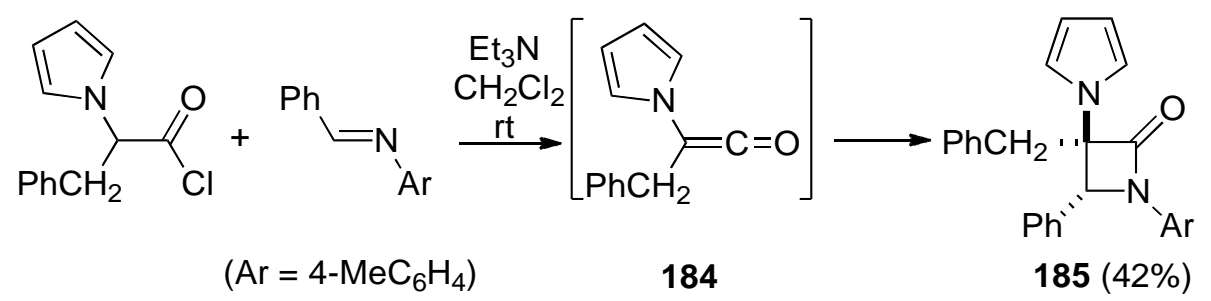

Scheme 78. Cycloaddition of an $N$-pyrrolylketene with imines.

Carboxylic acid activation with Mukaiyama's reagent 186 followed by imine addition gave the $\beta$-lactam 188, evidently through the intermediacy of ketene 187 (Scheme 79). ${ }^{119}$ (See also Scheme 37 and ref. 69).

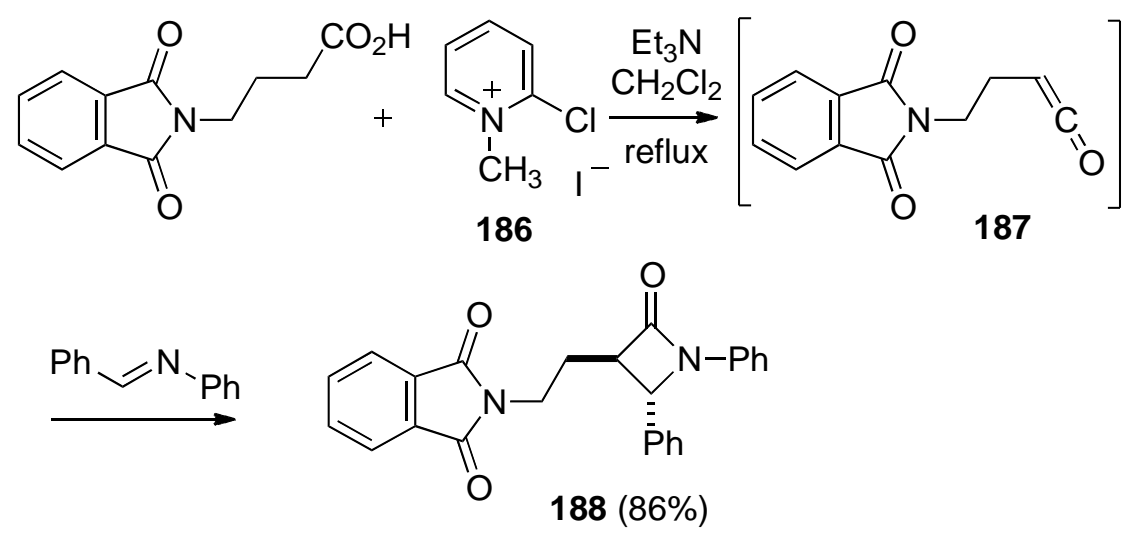

Scheme 79. Ketene generation with Mukaiyama's reagent and cycloaddition with imines.

Saccharin-substituted ketene 189, generated by carboxylic acid dehydration with Mukaiyama's reagent 186, reacted with imines to produce saccharin-substituted $\beta$-lactams, including 190 (Scheme 80), which was tested for biological activity. ${ }^{120}$ Mukaiyama's reagent also was used to generate other ketenes for $\beta$-lactam formation. Ketene $\mathbf{1 8 9}$ generated similarly also reacted with the stable free radical TEMPO forming 191, confirming the identity of the free ketene (Scheme 80). ${ }^{120}$

The new triflyl-substituted ketene 192, generated by thermal diazoketone Wolff rearrangement, gives [2+2] cycloaddition with imines forming the corresponding substituted $\beta$-lactams (Scheme 81). ${ }^{121}$ 

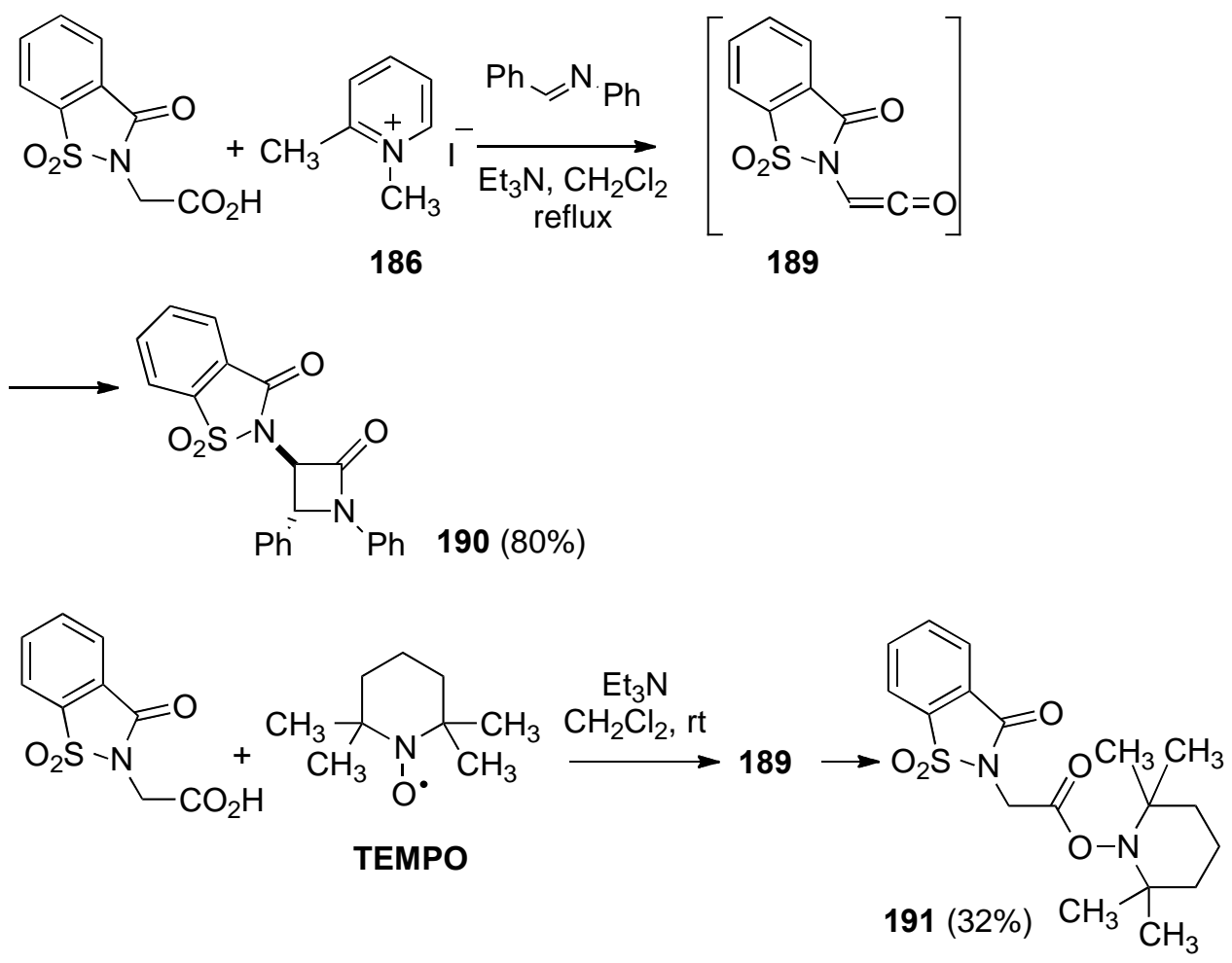

Scheme 80. Generation and reactivity of a saccharin substituted ketene.

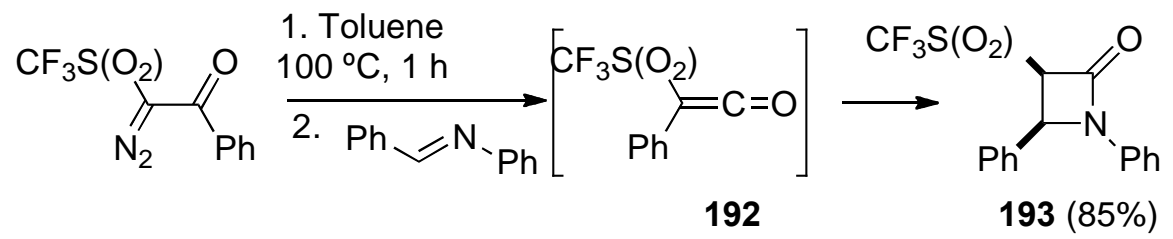

Scheme 81. Cycloaddition of a triflyl-substituted ketene.

Reaction of ketenes including 132 with catalysis by $N$-heterocyclic carbene 194 forms azolylium enolate 195, which was isolated, and the X-ray structure of 195 was determined. Reaction of 195 with imines formed $\beta$-lactams such as $\mathbf{1 9 6}$ (Scheme 82). ${ }^{122}$

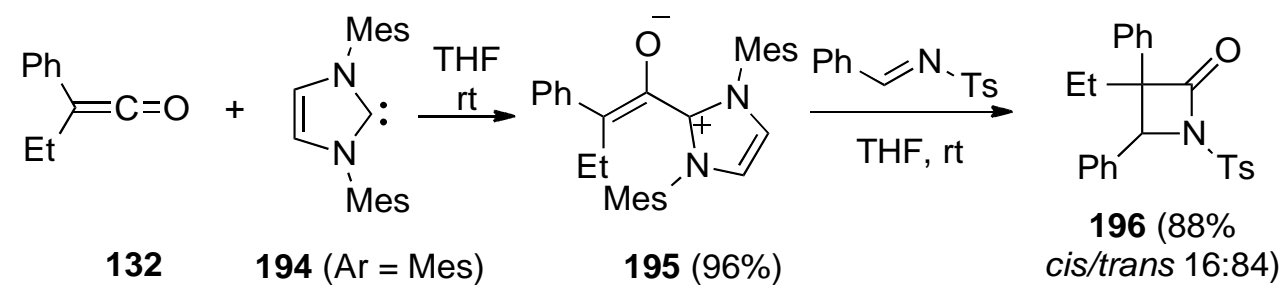

Scheme 82. Azolylium enolates from ketenes and conversion into $\beta$-lactams. 
Reactions of pyridazines such as 197 with dimethylketene (141) generated in situ from isobutyryl chloride give the spiro- $\beta$-lactam 198 by ketene-imine [2+2] cycloaddition (Scheme 83). This and similar products are used in the synthesis of pyrrolo[2,3-c]pyridazin-6-ones. ${ }^{123}$

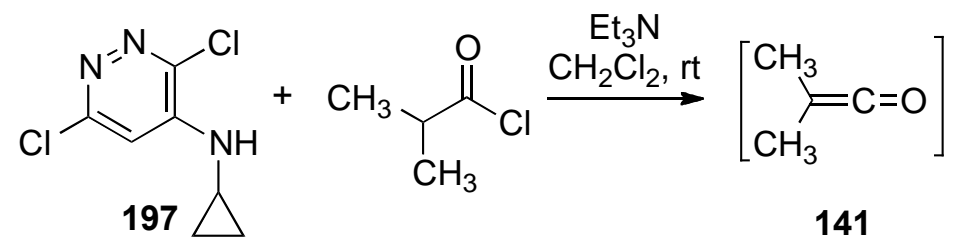<smiles>CC(C)C(=O)N1N=C(Cl)C2(C=C1Cl)N(C1CC1)C(=O)C2(C)C</smiles>

Scheme 83. Spiro- $\beta$-lactam from ketene cycloaddition with pyridazines.

The reactions of difluoroketene (199) with imines including 200 forming 202 were interpreted by computational studies as involving a [2+2] cycloaddition by a stepwise process through intermediate 201 (Scheme 84). ${ }^{124}$

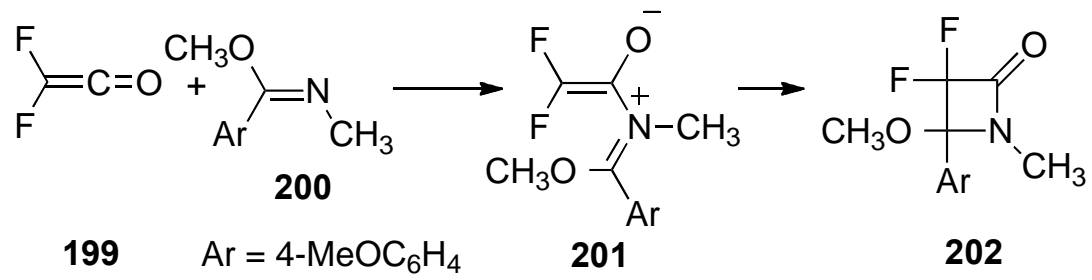

Scheme 84. Difluoroketene cycloaddition with imines.

A computational study of the Kinugasa reaction of phenylacetylene with nitrone $\mathbf{2 0 3}$ catalyzed by the copper-phenanthroline ligand L (204) favors a pathway with formation of complex 205 leading to intermediate 206 which ring opens to the ketene intermediate 207 which undergoes a cycloaddition forming the product $\beta$-lactam 208 (Scheme 85). ${ }^{125}$ The calculated structure of $\mathbf{2 0 7}$ is shown in Figure 11. 

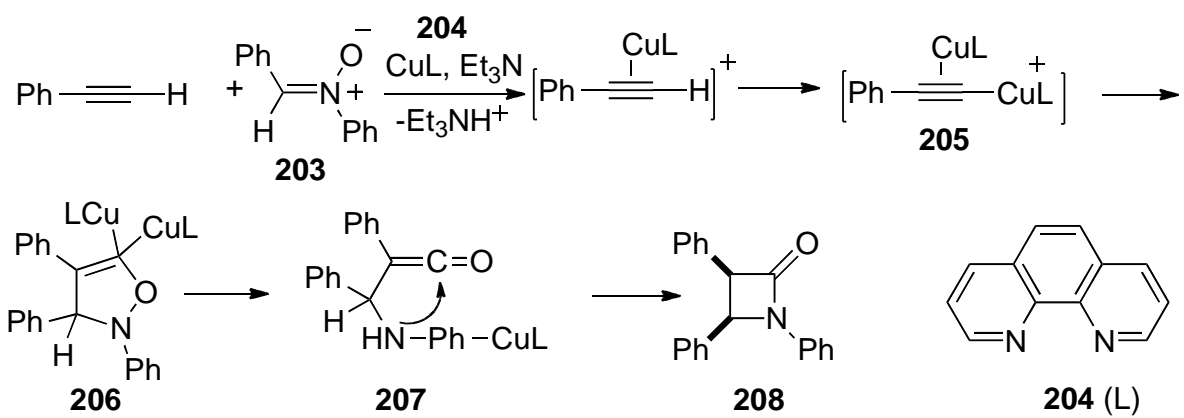

Scheme 85. Kinugasa reaction of phenylacetylene with a nitrone.

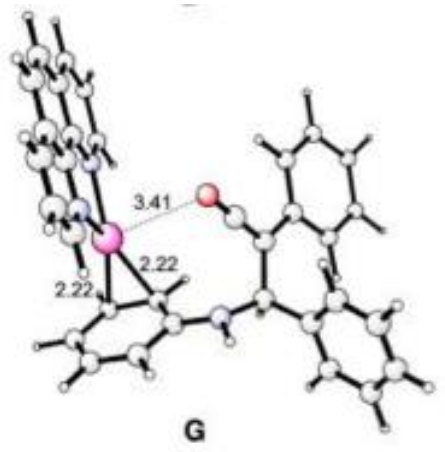

Figure 11. Calculated structure of Kinigusa intermediate for $\beta$-lactam formation (Reproduced with permission from the publisher ${ }^{125}$ ).

Acyl chloride dehydrochlorination with $N$-methylpiperidine in dichloromethane in a flow reactor with in-line monitoring by IR of the reactant and final product proceeded through the unobserved ketene 210, which reacts in situ with the imine 209 forming the $\beta$-lactam 211 (Scheme 86). ${ }^{126}$

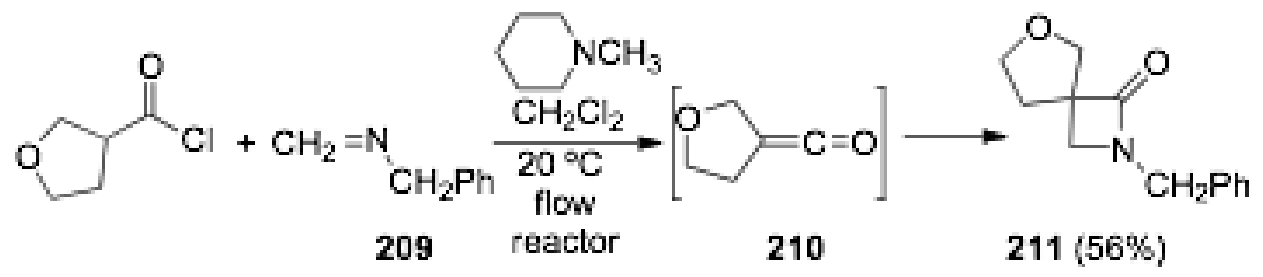

Scheme 86. Ketene-imine reaction in a flow reactor.

The selectivity in the reaction of chlorocyanoketene (212) with vinylimines by [2+2] and [4+2] cycloadditions forming $\beta$ - and $\delta$-lactams, respectively (Scheme 87 ), has been studied by computational methods. Topological analysis indicates that the reactions do not occur by onestep electrocyclizations. ${ }^{127}$ 


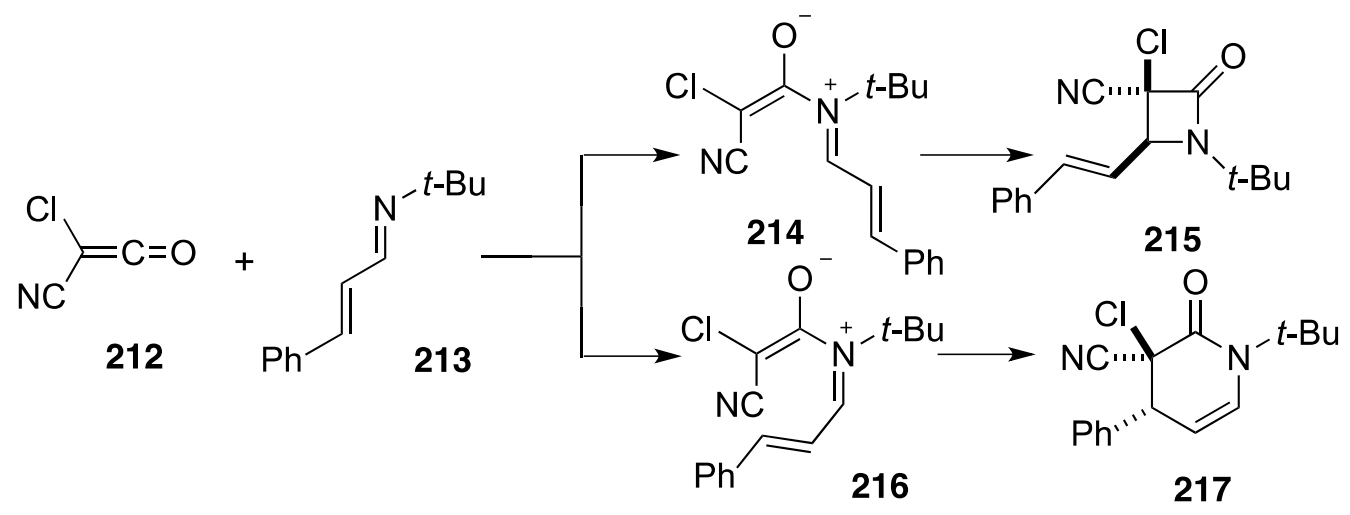

Scheme 87. Competitive [2+2] and [4+2] ketene-vinylimine cycloaddition.

Phenoxyketene (172) reacts with the bis(imine) 218 by double trans-[2+2] cycloaddition giving the diastereomeric bis- $\beta$-lactams 219 in a $50 \%$ overall yield (Scheme 88 ). The bis- $\beta$ lactams were evaluated for antimicrobial activity. ${ }^{128}$
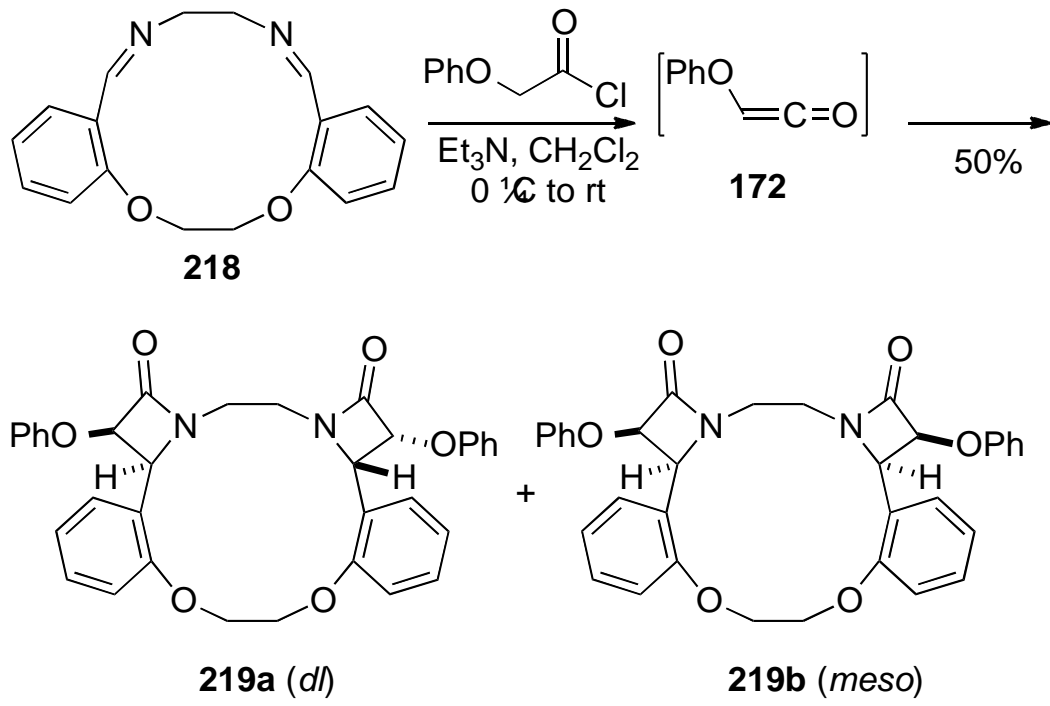

Scheme 88. Phenoxyketene cycloaddition with a bis-imine.

Adipoyl chloride $\mathbf{2 2 0}$ ) reaction with triethylamine promoted by ultrasound irradiation in the presence of 2-aminothiazole and zeolite gives formal generation of bisketene 221, which reacts by a double [2+2] cycloaddition with the in situ generated imine $\mathbf{2 2 2}$ forming the bis- $(\beta$-lactam) 223 (Scheme 89). ${ }^{129}$ 


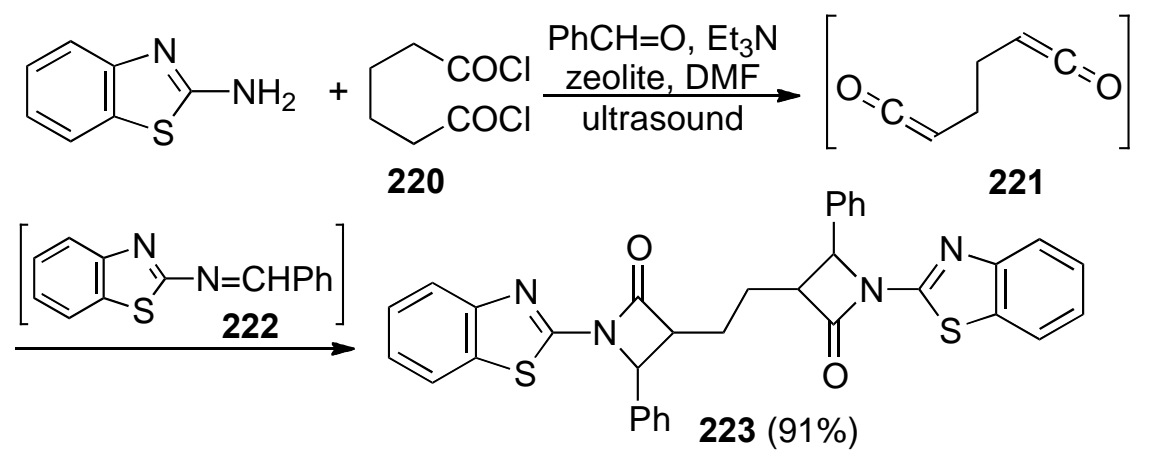

Scheme 89. Bis-( $\beta$-lactam) formation from a bis(acyl chloride).

Dehydrochlorination of bis(acyl chlorides) in the presence of imines forming ketenes which react with formation of bis- $\beta$-lactams was examined in a further study by computational and experimental methods. ${ }^{130}$ With pentanedioyl dichloride (224) bis- $\beta$-lactams 225 and 226 were formed at reflux as cis/trans mixtures (Scheme 90), but the conceivable formation of the bisketene 227 under these conditions was considered to be unlikely. Adipoyl chloride (220) at room temperature formed 231, proposed to result from initial dehydrochlorination with chlorine migration via $\mathbf{2 2 8}$ to $\mathbf{2 2 9}$ (Figure 12), followed by dehydrochlorination to the acyl ketene $\mathbf{2 3 0}$, which reacts further by [4+2] cycloaddition forming $\mathbf{2 3 1}$ (Scheme 91). ${ }^{130}$

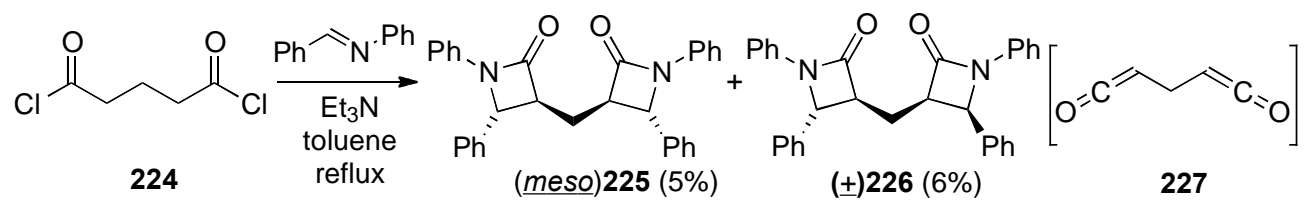

Scheme 90. Bis- $\beta$-lactam formation through a formal 1,1-bisketene.

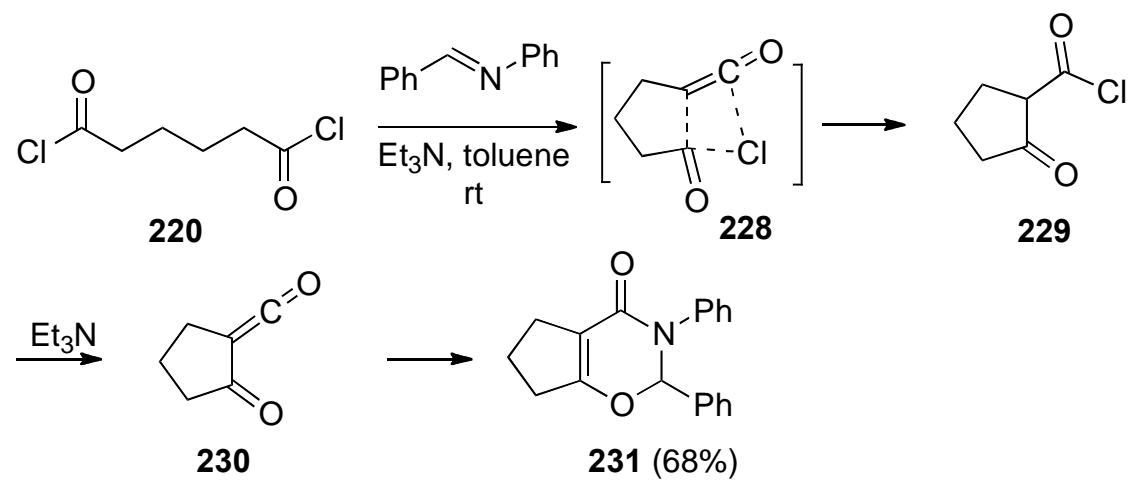

Scheme 91. Chlorine migration in reaction of a bis(acyl chloride). 


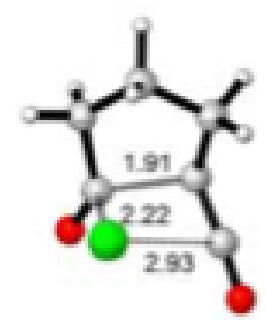

Figure 12. Calculated transition state for chlorine migration during ketene formation (Reprinted with permission from the Publisher ${ }^{130}$ ).

Butadienylketene (234) generated by dehydrochlorination of 232 reacts with the 1,4-diazabuta-1,3-diene 233 forming the mono(cis- $\beta$-lactam) 235 and bis(cis- $\beta$-lactam) 236 (Scheme 92). ${ }^{131}$

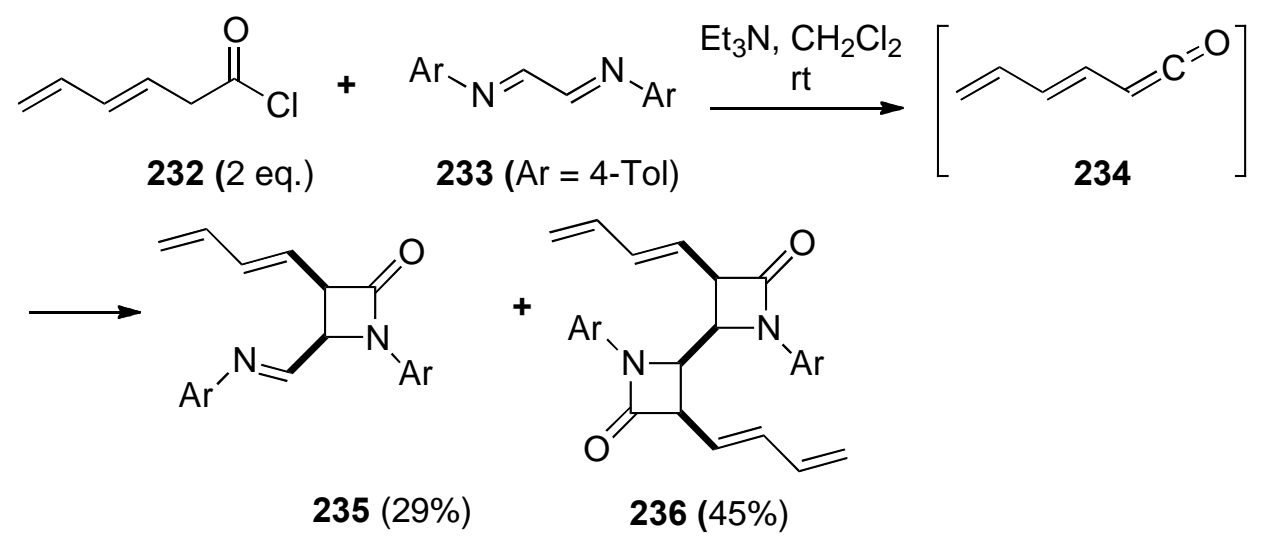

Scheme 92. Dienyl $\beta$-lactams from a glyoxal bis-imine.

\section{5. $[2+2+2]$ Cycloadditions}

The reaction of acyl chloride $\mathbf{2 4 6}$ with a chiral oxazolidinone substituent and trifluoroacetic anhydride and acetone forming $\mathbf{2 4 9}$ was suggested to proceed by formation the ketene $\mathbf{2 4 7}{ }^{132}$ which undergoes trifluoroacetylation by a process proposed earlier, ${ }^{133}$ leading to $\mathbf{2 4 8}$ by trifluoroacetylation of the ketene, and then 249, incorporating the ketene, acetone, and a trifluoroacetyl group in a net $[2+2+2]$ cycloaddition (Scheme 93). ${ }^{132}$ Note that the final step forming the dioxinone $\mathbf{2 4 9}$ is the reverse of the ketene-generating reactions described in Section 3.7. The product was used in the stereoselective preparation of $(2 R, 3 S)-4,4,4$-trifluoro-allothreonine (250). 

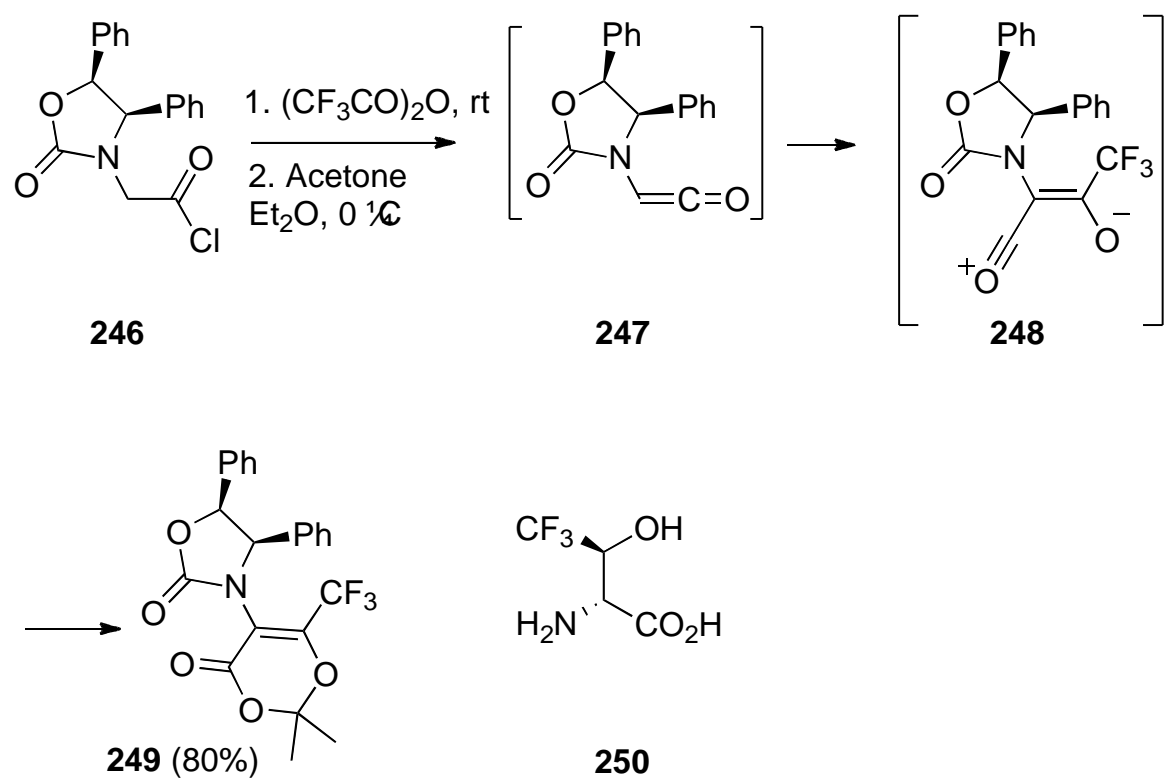

Scheme 93. Ketene trifluoroacetylation and capture with acetone.

\section{6. [3+2] Cycloadditions involving ketenes}

Ketene, having a linear skeleton, is not the right shape to provide three atoms in a [3+2] cycloaddition. The precursor of a ketene in the Wolff rearrangement, an acylcarbene (or carbenoid), can so react, as was recently reported by Russian workers. ${ }^{134}$ The diazodiketone 251 in the presence of dirhodium tetraacetate or tetraoctanoate is suggested to generate a rhodium carbenoid which reacts with the $2 H$-azirine 252 in a [3+2] cycloaddition forming the intermediate 254, which rearranges to 255 , and reacts further with acetyl methyl ketene 253 , also formed by rearrangement of the carbenoid, by 1,2- and 1,4-cycloadditions, forming 256-258. (Scheme 94) A number of analogous reactions were studied. ${ }^{134}$
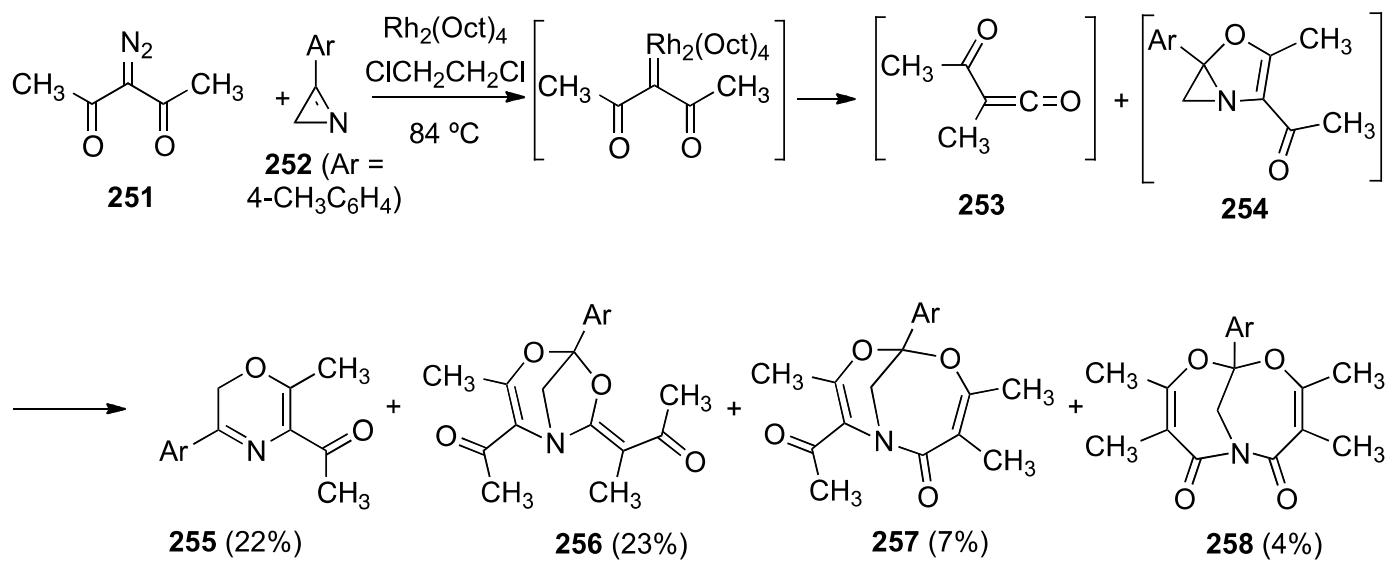

Scheme 94. Ketene-imine cycloaddition with rearrangement and further reactions. 
$N^{\prime}$-(2-Alkynylbenzylidene)hydrazides (259) react with ketenes such as $\mathbf{1 5 9}$ with catalysis by silver triflate forming fused 2,6-diazabicyclo[3.2.2]non-6-en-3-ones (263) in a process interpreted as involving an initial [3+2] cycloaddition with $\mathbf{2 6 0}$ formed in situ leading to $\mathbf{2 6 1}$ which ring-opens to $\mathbf{2 6 2}$ which then cyclizes to $\mathbf{2 6 3}$ (Scheme 95). ${ }^{135,136}$
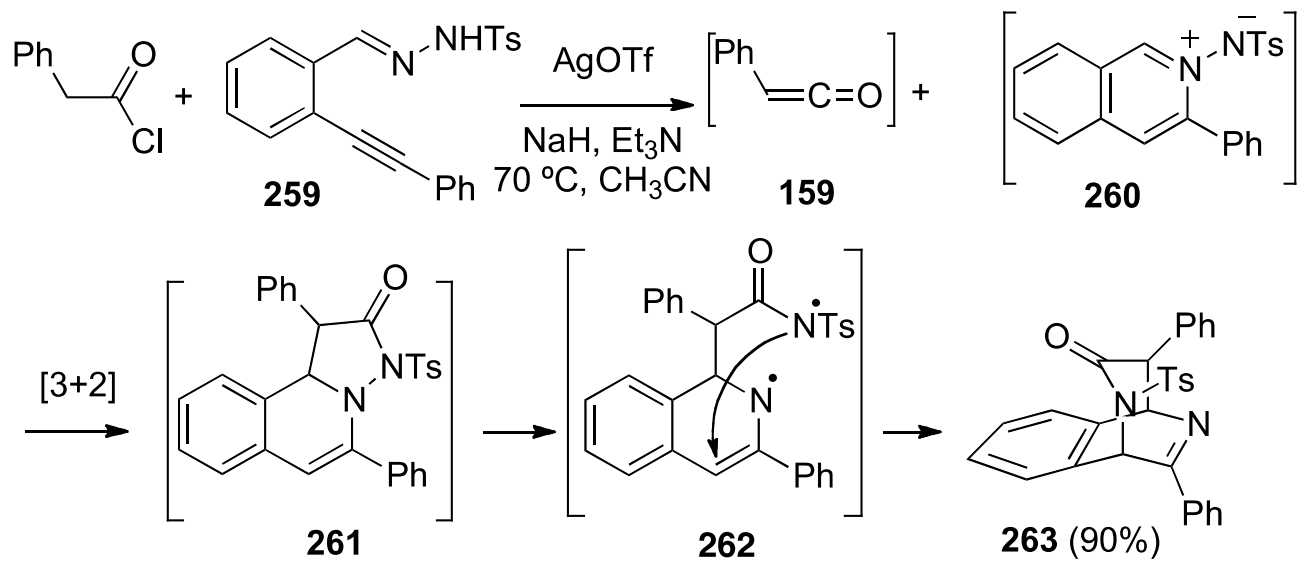

Scheme 95. Ketene [3+2] cycloaddition with $N^{\prime}-(2$-alkynylbenzylidene)hydrazides.

tert-Butylcyanoketene (266), generated in situ by thermolysis of quinone 264 by the method of Moore et al., ${ }^{137}$ reacts with the epoxide 265 forming 267 by a net [3+2] cycloaddition (Scheme 96). ${ }^{138}$

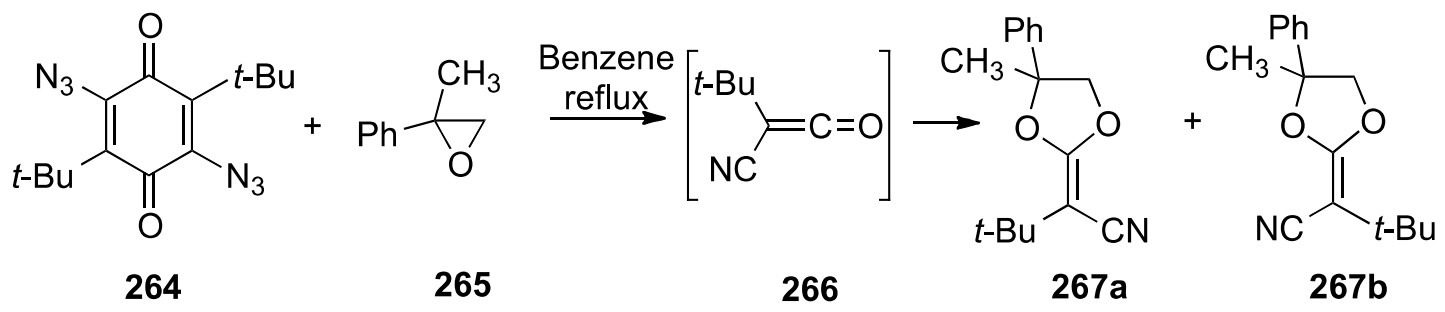

Scheme 96. Generation of tert-butylcyanoketene and reaction with 2-methyl-2-phenyloxirane.

Arylalkylketenes react with $L$-serine-derived $N$-arylnitrones 268 with enantioselective formation of 3-alkyl-3-aryloxindoles $\mathbf{2 7 1}$ in a process interpreted as involving an initial [3+2] cycloaddition on the ketene carbonyl forming $\mathbf{2 6 9}$ followed by a [3+3] electrocyclization forming 270. Hydrolysis yields the oxindole 271 (Scheme 97). ${ }^{139}$ 


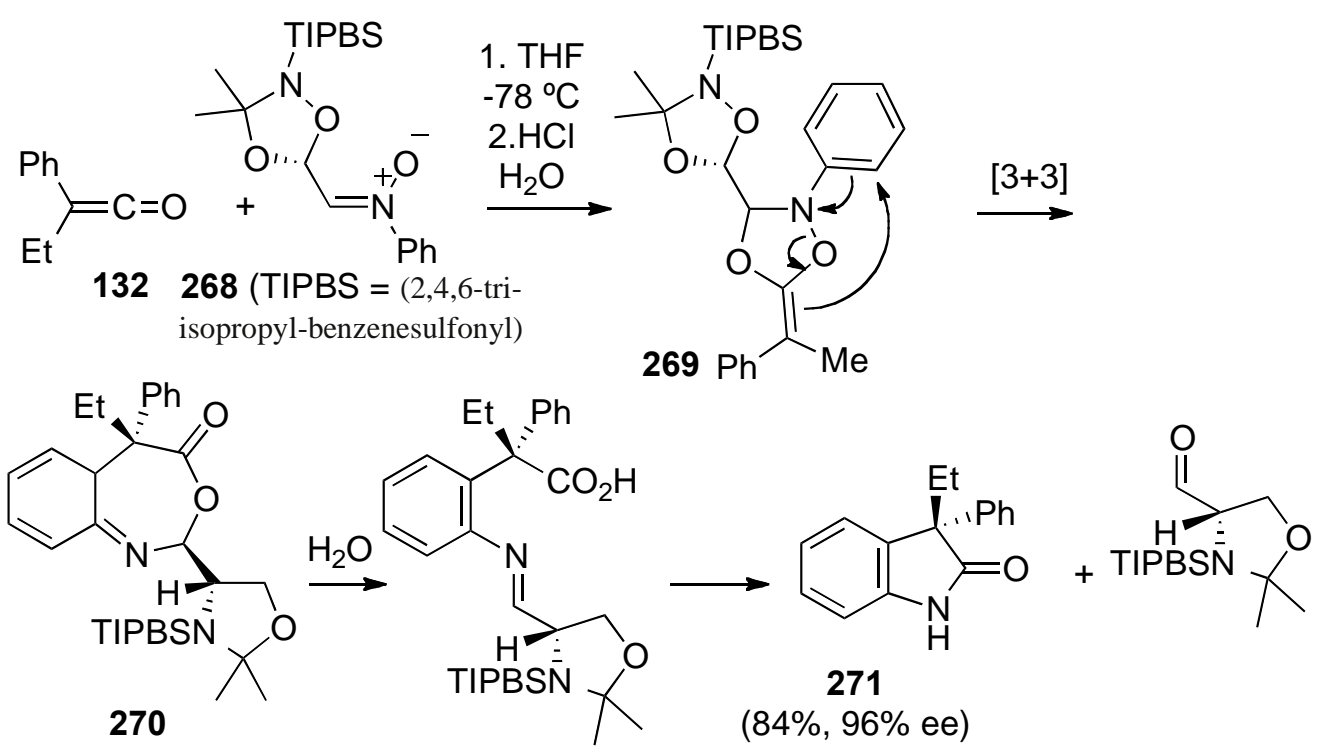

Scheme 97. Enantioselective formation of 3-alkyl-3-aryloxindoles by [3+2] ketene carbonyl cycloaddition followed by [3+3] electrocyclization and hydrolysis.

The frustrated Lewis ion pair 272 is suggested to react with ketene 273 generated by acyl chloride dehydrohalogenation, and the ketene reacts with a second molecule of $\mathbf{2 7 2}$ by formal [3+2] cycloaddition to form 274 (Scheme 98). ${ }^{140}$

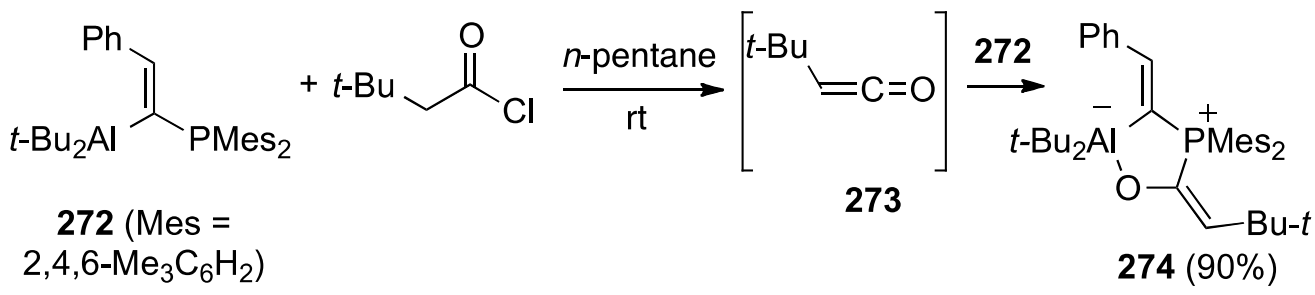

Scheme 98. Ketene reaction with a frustrated ion pair.

Computational studies of cycloaddition reactions of ketenes $\mathrm{CH}_{3} \mathrm{CR}=\mathrm{C}=\mathrm{O}$ with $\mathrm{ReO} 3 \mathrm{Cl}$ forming products such as 275 (Scheme 99) and with manganese oxo complexes $\mathrm{MnO}_{3} \mathrm{~L}(\mathrm{~L}=\mathrm{Cl}$, $\mathrm{O}-, \mathrm{OCH}_{3}, \mathrm{CH}_{3}$ ) (Scheme 99), forming 276 and 277, have been reported. ${ }^{141,142}$

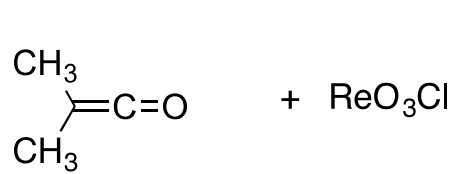

141

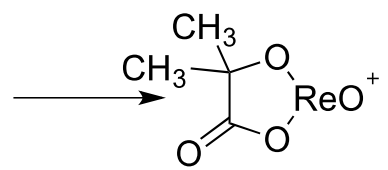

275

Scheme 99. Computations of dimethylketene reaction with metal oxides. 


\subsection{Ketene [4+2] cycloadditions and cyclizations}

Thermolysis of carbamoyl Meldrum's acid 278 forms ketene 279 that undergoes net [4+2] cycloaddition with imine $\mathbf{2 8 0}$ forming the 5-carbamoyl-1,3-oxazine-4,6-dione $\mathbf{2 8 1}$ (Scheme 100). ${ }^{143}$<smiles>CC1(C)OC(=O)C(=C(O)Nc2ccccc2)C(=O)O1</smiles>

278

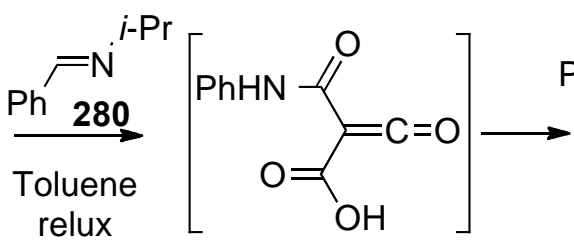

279<smiles>CPN1C(=O)C(C(=O)Nc2ccccc2)C(=O)OC1c1ccccc1</smiles>

$281(46 \%)$

Scheme 100. Carboxyketene-imine [4+2] cycloaddition.

Diversely substituted acylketenes including 282 generated from dioxinones give [4+2] cycloadditions with isocyanates (forming $\mathbf{2 8 3}$ ) and isothiocyanates (Scheme 101). ${ }^{144}$

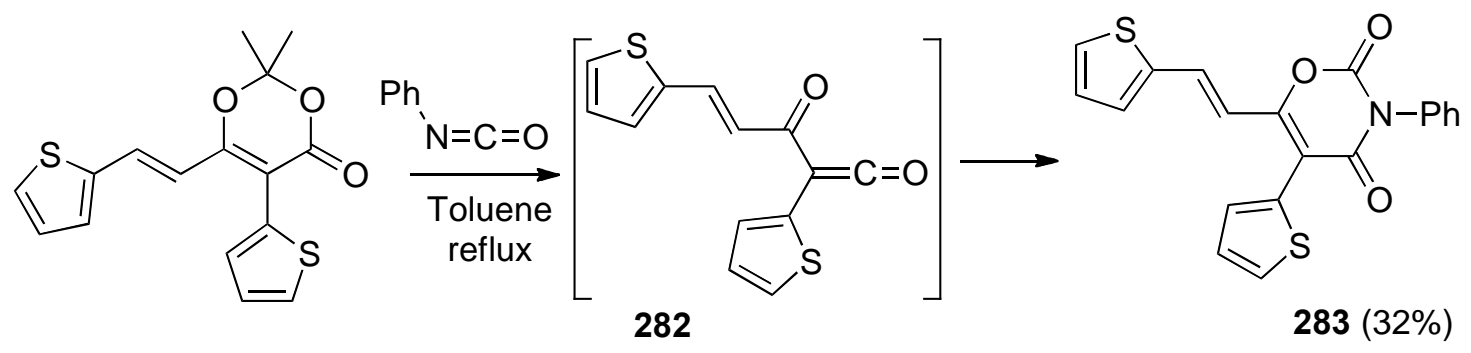

Scheme 101. Acylketene/isocyanate [4+2] cycloaddition.

Bromoketene (285), generated by dehydrochlorination of bromoacetyl chloride, reacts by a aza-Diels-Alder reaction with 2-arylideneamino-4-arylthiazoles including $\mathbf{2 8 4}$ forming the product thiazolo[3,2-a]pyrimidin-5-ones (286) (Scheme 102). ${ }^{145}$<smiles>O=C(Cl)CBr</smiles>

284

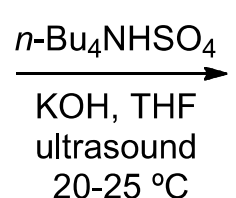

$20-25^{\circ} \mathrm{C}$<smiles>O=C1C(Br)[C@H](c2ccccc2)N=C2SC=C(c3ccccc3)N12</smiles>

$286(71 \%)$

Scheme 102. Aza-Diels-Alder reaction with bromoketene.

Ketene generated in situ by dehydrochlorination reacts with substituted salicylaldehydes including 287 by a net [4+2] cycloaddition leading to coumarin products 288 (Scheme 103). ${ }^{146}$ 

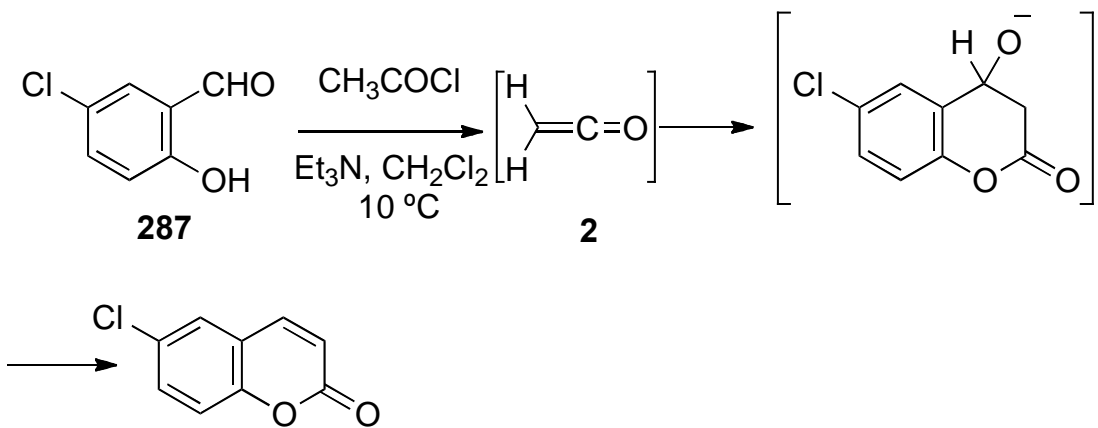

$288(64 \%)$

Scheme 103. Ketene [4+2] cycloaddition with salicylaldehydes.

Amino-substituted diazoketones react with alkynes forming diazo-keto esters which are directly treated with silver salts giving, by Wolff rearrangement, the corresponding ketenes, including 289, which cyclize by intramolecular nucleophilic addition to enaminones (290; Scheme 104), which are used in alkaloid synthesis. ${ }^{147-149}$

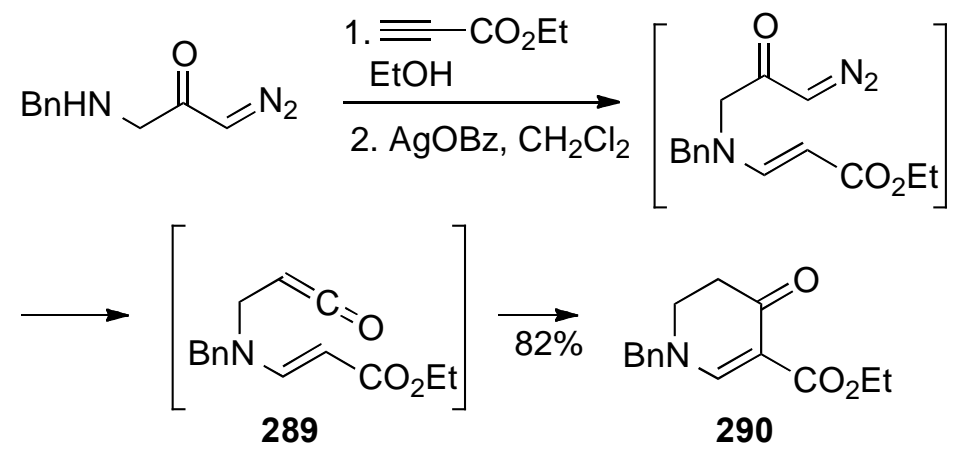

Scheme 104. Ketene formation by Wolff rearrangement and intramolecular nucleophilic substitution.

Ketene 292, generated by thermal Wolff rearrangement of 3-diazoquinolin-4-one 291 in refluxing acetic anhydride, gave 293 by an intramolecular Friedel-Crafts [4+2] cyclization (Scheme 105). ${ }^{150}$

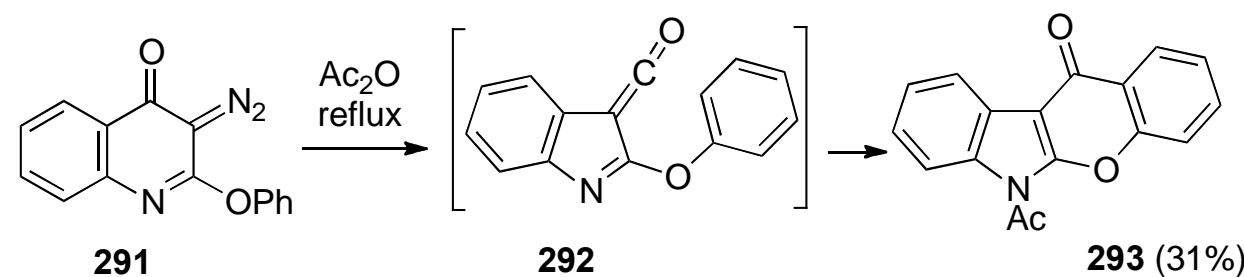

Scheme 105. Intramolecular ketene Friedel-Crafts [4+2] electrophilic cyclization. 
Extended vinylketenes including 295 are formed by [1,5]-hydrogen transfer upon photolysis of 1,3-butadienyl-2-benzaldehydes 294, and are converted into benzobicycloheptanones 296 by intramolecular Diels-Alder reaction (Scheme 106). Ketene formation under these conditions was demonstrated by capture of the ketene with piperidine. Computational studies of the transition state for the proposed $[1,5]-\mathrm{H}$ shift are consistent with the observed chemoselectivity. ${ }^{151}$

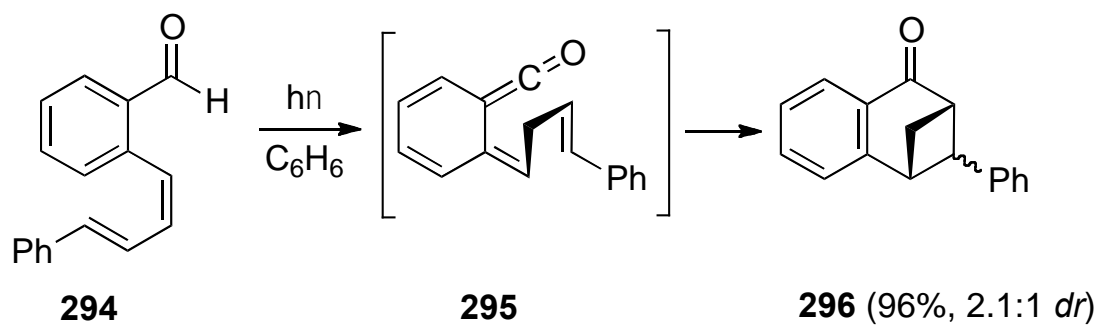

Scheme 106. Intramolecular ketene Diels-Alder reaction.

The question of whether the ring closure of ketene 297 to 298 , and of 299 to $\mathbf{3 0 0}$ (Scheme 107 ), occurs by a pericyclic or a pseudopericyclic mechanism has been studied by computational methods, and it was confirmed in both cases that it occurs by a pseudopericyclic reaction mechanism. ${ }^{152}$

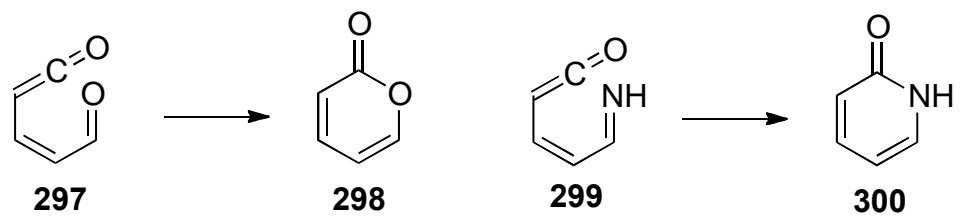

Scheme 107. Pseudopericyclic cyclization of vinylketenes.

Chlorocarbonylketenes such as $\mathbf{3 0 1}$ take part in [3+3] cycloaddition and elimination with $N$ phenylthiocarbamates $\mathbf{3 0 2}$ giving unstable mesoionic 1,3-thiazinium-4-olates 303, which undergo alkene elimination forming 3,5-diaryl-1,3-thiazine-2,4,6-triones 304 (Scheme 108). ${ }^{153}$ 

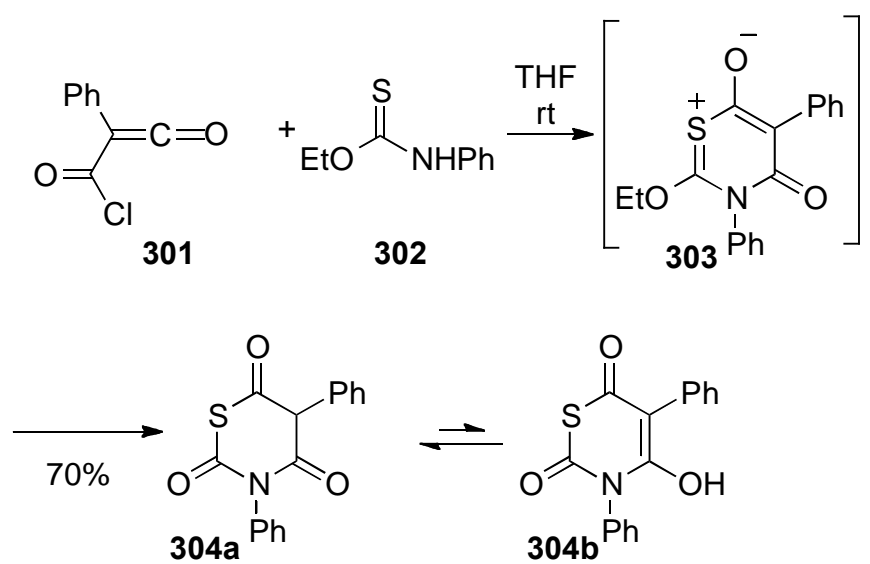

Scheme 108. Chlorocarbonylketene cycloaddition and elimination.

In an asymmetric inverse electron-demand Diels-Alder cycloaddition catalysed by the chiral $N, N^{\prime}$-dioxide gadolinium complex $(S)$-L-PiPr 2 derived from $(S)$-pipecolic acid, the ketene 305 and 3-alkenyloxindole 306 form the indolo-fused dihydropyranone 307 (Scheme 109). ${ }^{154}$

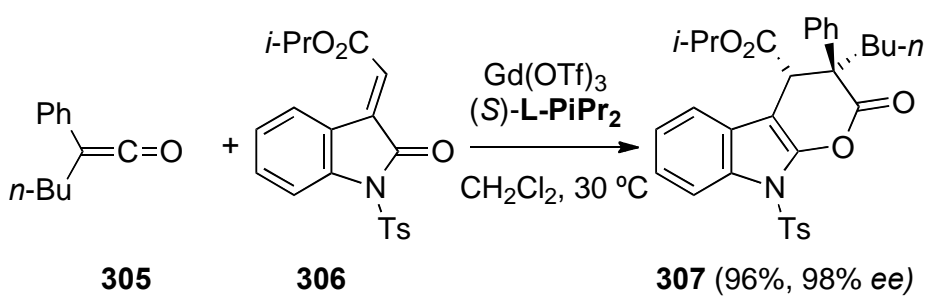

Scheme 109. Ketene asymmetric inverse electron demand Diels-Alder reaction.

Arylalkylketenes including 132 react with $\alpha$-cyanochalcones by [4+2] cycloaddition in the presence of the chiral $N$-heterocyclic carbene catalyst generated from $\mathbf{3 0 8}$ forming dihydropyranones 309 (Scheme 110). ${ }^{155}$

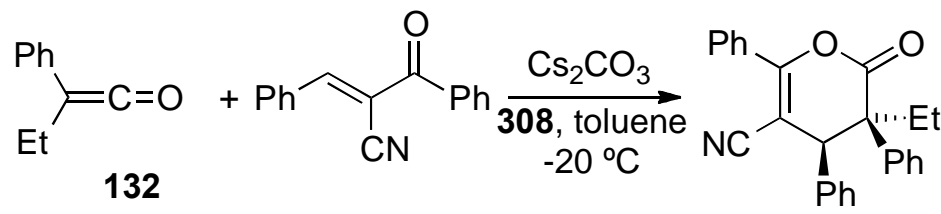

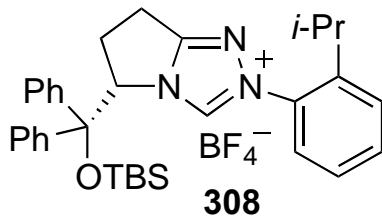

$309(66 \%$, dr $4: 1,96 \%$ ee)

Scheme 110. Arylalkylketene [4+2] cycloaddition with $\alpha$-cyanochalcones. 
Other examples of [4+2] cycloadditions after this model (the ketene providing the 2-atom element in the cyclization) have been referred to earlier (Schemes 63, 102). Scheme 62 features [4+2] cycloaddition of a vinylketene to an ynamine.

Acetyl chloride reacts with the frustrated phosphane/borane Lewis pair $\mathbf{3 1 0}$ in a reaction interpreted as proceeding through the ketene (2) generated in situ and then formation of the P/B adduct $\mathbf{3 1 1}$ (Scheme 111). ${ }^{156}$

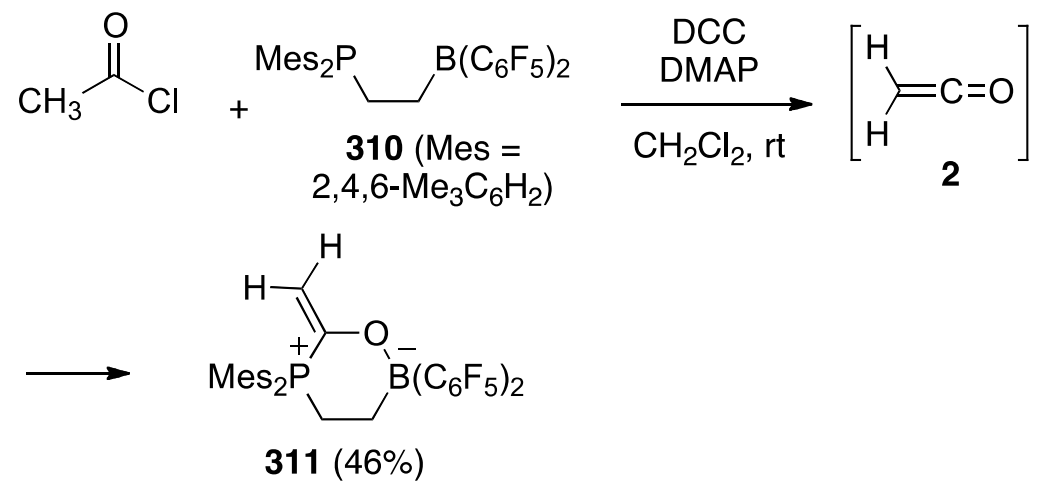

Scheme 111. Ketene [4+2] cycloaddition with a frustrated phosphane/borane Lewis pair.

Reaction of norlobelanine (312) with ethylketene (313), generated from butyryl chloride with sodium hydride, triethylamine, and 15-crown-6, formed quinolizidinone 314 in a twocomponent domino ketene amination/intramolecular aldol reaction (Scheme 112). ${ }^{157}$

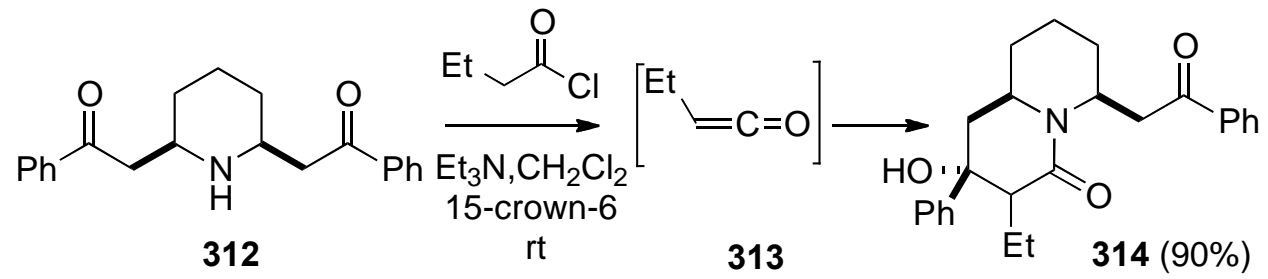

Scheme 112. Ketene [4+2] cycloaddition with norlobelanine.

Acetylketene (113) generated from thioester 315 in the presence of silver trifluoroacetate reacts with the imine $\mathbf{3 1 6}$ by [4+2] cycloaddition forming 2,3-dihydro-1,3-oxazin-4-ones 317 (Scheme 113). ${ }^{158}$<smiles>CC(=O)CC(=O)[Sb+2]c1ccccc1</smiles> 
Scheme 113. Acetylketene [4+2] cycloaddition with imines.

The 1,4-addition of a cinnamylideneimine to chlorocyanoketene, forming a dihydropyridone, was noted in Scheme 87

\section{Nucleophilic Additions to Ketenes}

\subsection{Hydration and addition of other oxygen nucleophiles}

The mechanism of ketene hydration has long been the subject of experimental and computational studies, and a recent computational study of this process with two water molecules concludes that the reaction occurs by formation of the ene-diol $\mathrm{H}_{2} \mathrm{C}=\mathrm{C}(\mathrm{OH})_{2}$, which then isomerizes to acetic acid (Scheme 114), ${ }^{159}$ in agreement with earlier interpretations. ${ }^{8,11}$ In the presence of formic acid as a catalyst this is suggested to participate in the addition, forming acetic acid directly (Figure 12). ${ }^{160}$

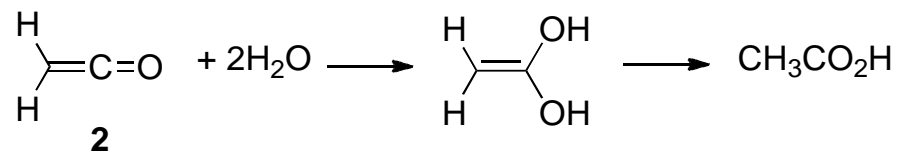

Scheme 114. Computational study of ketene hydration.

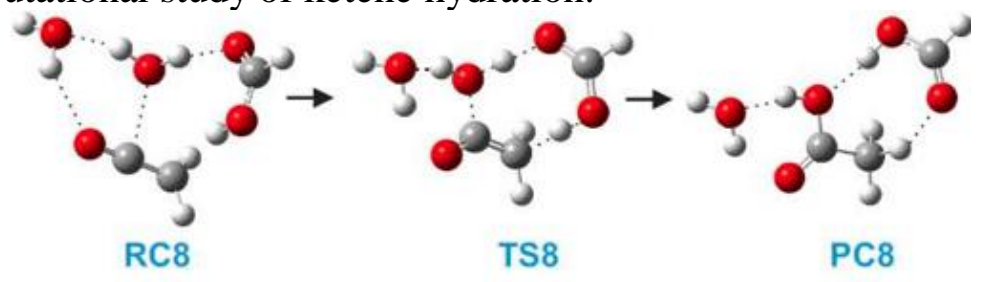

Figure 12. Ketene hydration with formic acid catalysis (Reprinted with permission from the American Chemical Society ${ }^{160}$ ).

An experimental study with infrared spectroscopic detection of gas-phase ketene generated by thermal cracking of acetone at $750{ }^{\circ} \mathrm{C}$ in the presence of water showed the formation of acetic acid, which reacts with further ketene to form acetic anhydride. ${ }^{161}$

Dioxinones attached to glass plates (318) upon thermolysis in the presence of neat hydroxypolyethers $\mathbf{3 1 9}$ form ketenes $\mathbf{3 2 0}$ on the surface as detected by X-ray photoelectron spectroscopy, and these ketenes add the alcoholic groups forming coated plates 321 (Scheme 115); the use of perfluorinated glycols formed potentially oil-repellent surfaces. ${ }^{162}$ 

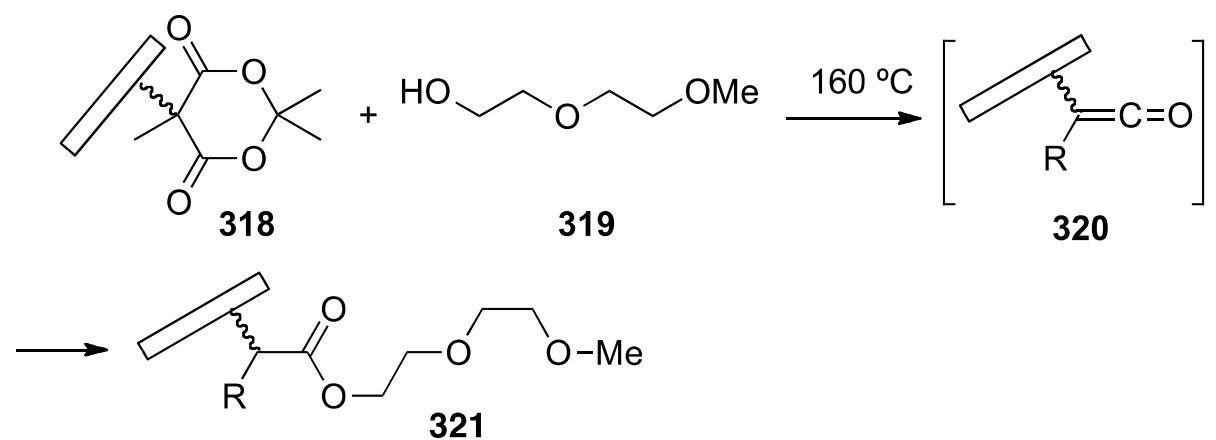

Scheme 115. Ketene generation and capture on a glass plate.

Ketene reactions with enantioenriched sulfoxonium ylides and aldehydes provide a synthesis of $\gamma$-lactones, as in the preparation of $\mathbf{3 2 5}$, proposed to occur by a complex process with initial nucleophilic attack on the ketene $\mathbf{3 2 2}$ by $\mathbf{3 2 4}$, formed from the sulfur ylide $\mathbf{3 2 3}$ and the aldehyde (Scheme 116). ${ }^{163}$

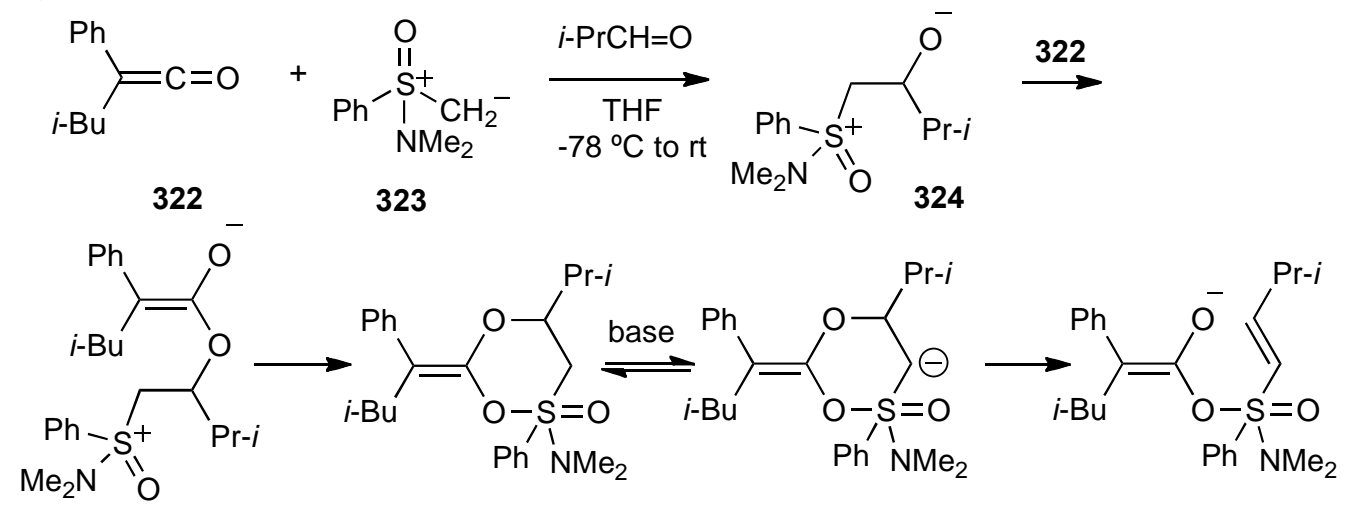

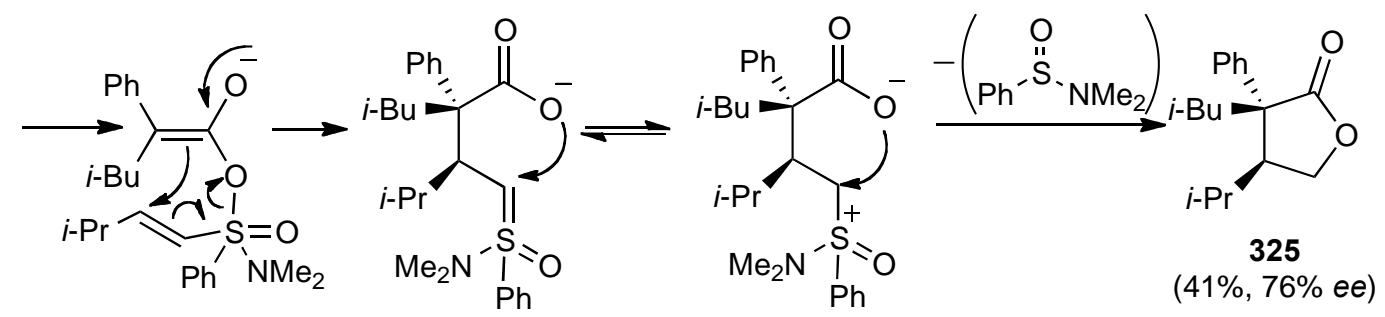

Scheme 116. $\gamma$-Lactones from ketene reaction with sulfoxonium ylides and aldehydes.

Acylketene 328 generated by pyrolysis of dioxinone $\mathbf{3 2 7}$ was used in the preparation of hirsutellone B (329) proceeding by a tandem nucleophilic addition to the ketene followed by an intramolecular Diels-Alder reaction (Scheme 117). ${ }^{164}$ 


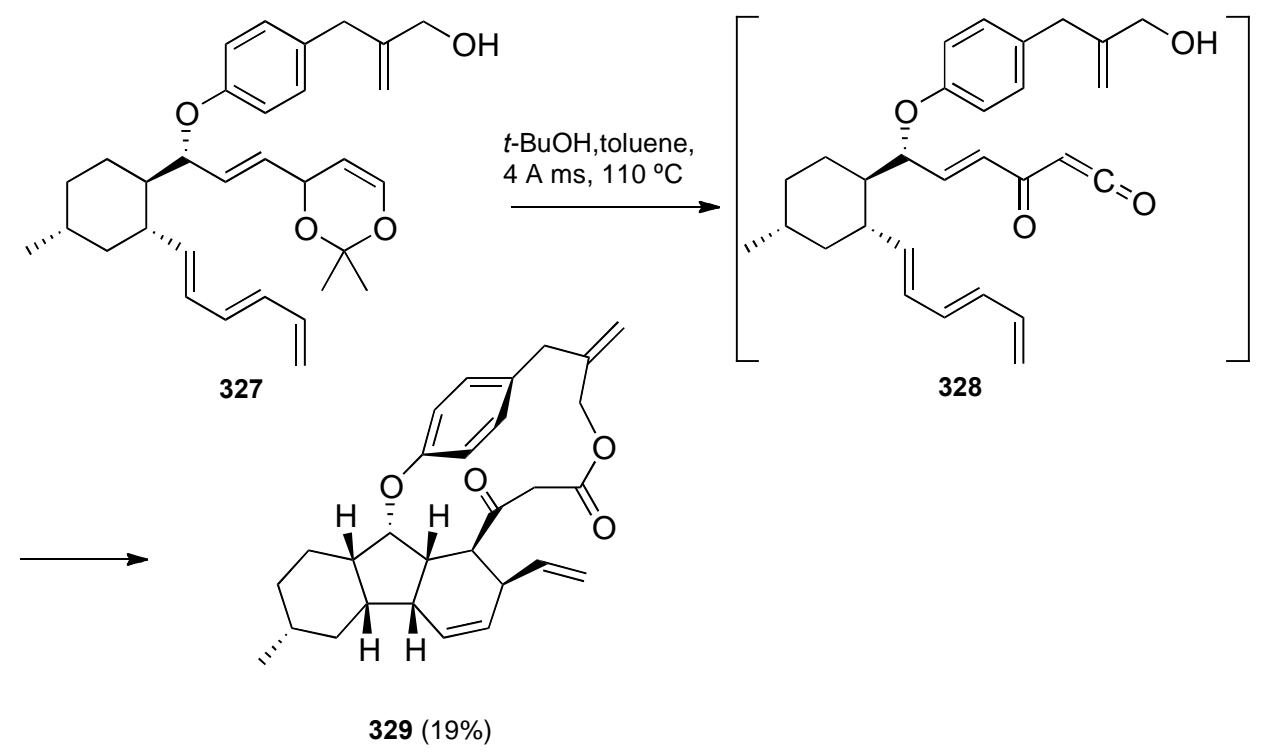

Scheme 117. Tandem ketene nucleophilic addition with subsequent intramolecular Diels-Alder reaction

Two ketene coupling reactions are used in a synthesis of lyngbyaloside C (337) from 330, beginning with generation of acyl ketene $\mathbf{3 3 1}$ by dioxinone thermolysis to form $\mathbf{3 3 2}$, a precursor of 333. This is converted to ketene $\mathbf{3 3 5}$ by silver triflate in the presence of $\mathbf{3 3 4}$ to form $\mathbf{3 3 6}$ (Scheme 118). ${ }^{165}$

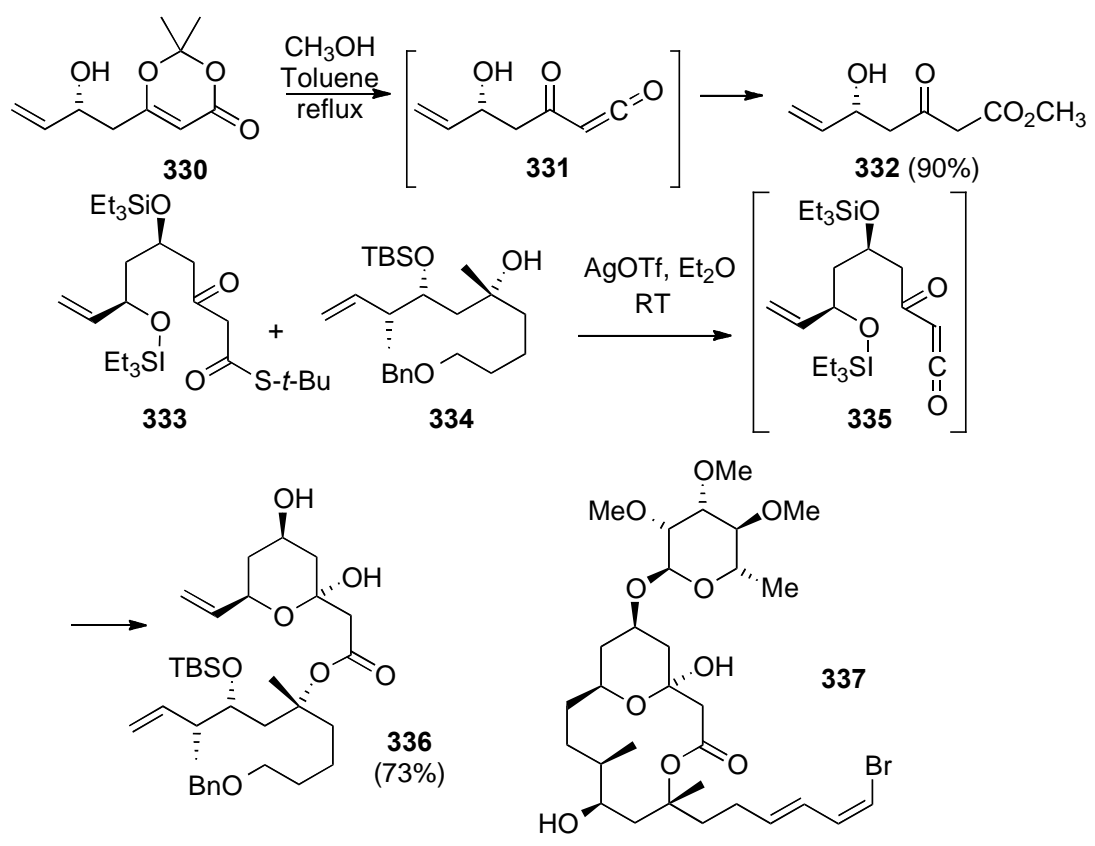

Scheme 118. Ketene coupling reactions in the synthesis of lyngbyaloside C. 
In a study of the total synthesis of viridicatumtoxin $B$, treatment of 338 with dimethyldioxirane (DMDO) at $-78{ }^{\circ} \mathrm{C}$ gave $\mathbf{3 4 0}$, in a process that may involve capture of acylketene 339, although this species was not observed directly (Scheme 119). ${ }^{166}$

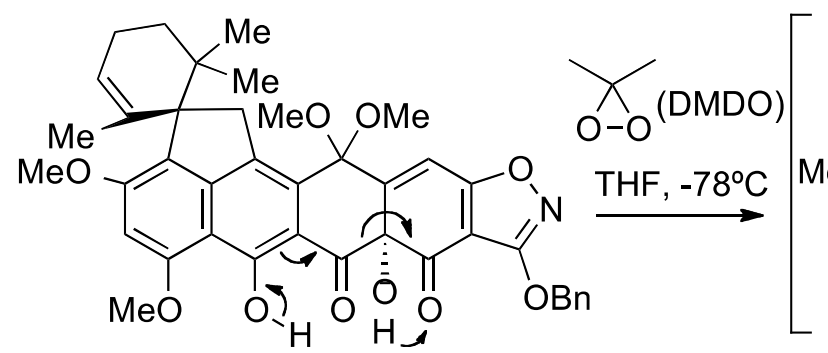

338

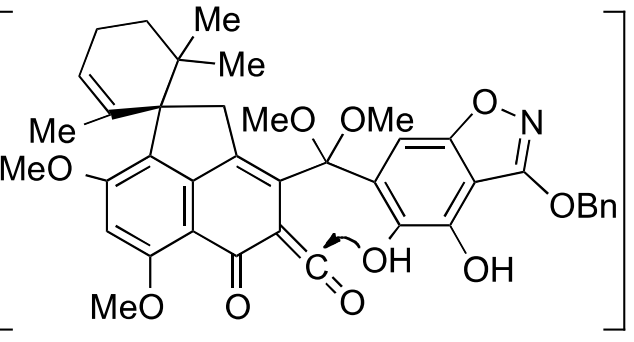

339

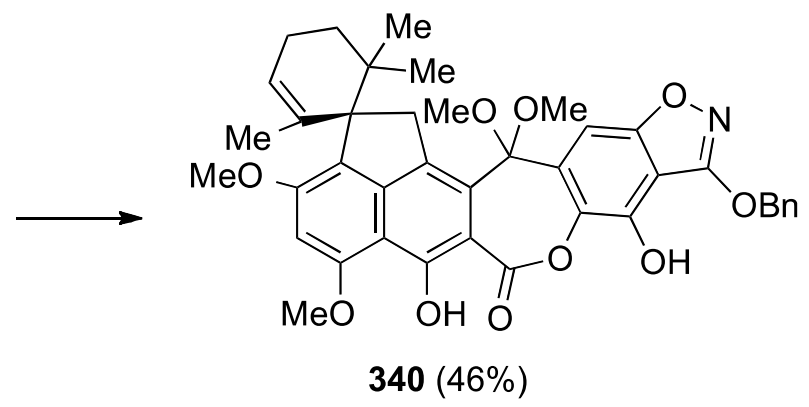

Scheme 119. Intramolecular ketene esterification in the synthesis of viridicatumtoxin B intermediates.
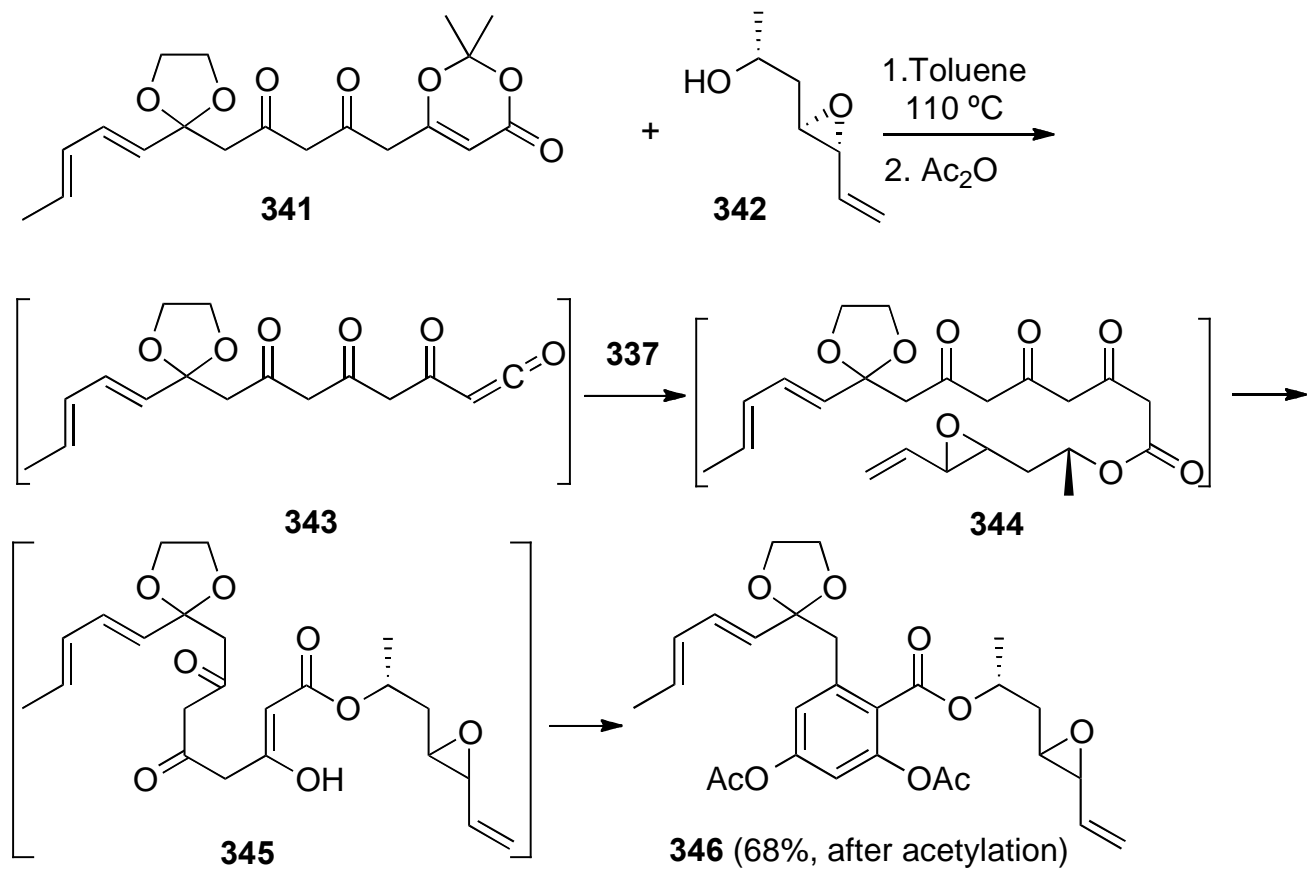

Scheme 120. Ketene esterification with product aromatization. 
Ketene 343 generated by thermolysis of the dioxinone 341 reacted with alcohol 342 to form the ester 344, used as a precursor in a total synthesis of radicicol, in a process suggested as proceeding through 344, which is converted through the intermediate enol $\mathbf{3 4 5}$ into the final product 346 by spontaneous aromatization followed by acetylation (Scheme 120). ${ }^{167}$

\subsection{Addition of nitrogen nucleophiles}

Phenylketene (159) reacts with tertiary amines, e.g. triethylamine, forming the observable zwitterionic intermediate 347 , which decays by reaction with a second amine in a reaction attributed to either competitive displacement of an alkyl group by the second amine, or an aminecatalyzed elimination (Scheme 121). ${ }^{168}$

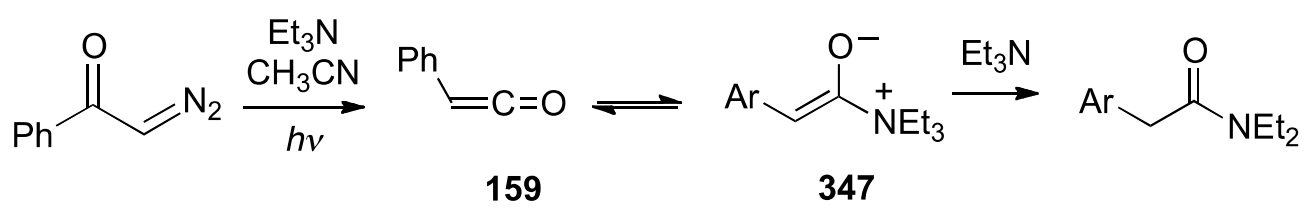

Scheme 121. Ketene reaction with tertiary amine with net dealkylation.

Cyclopropenone 348 reacts with amines in the presence of a phosphine catalysts forming unsaturated amide $\mathbf{3 5 0}$ in a reaction interpreted as proceeding through ketene intermediate 349 (Scheme 122). ${ }^{169}$ Lysozyme-substituted cyclopropenones were used similarly for ligation in biological systems. ${ }^{169}$
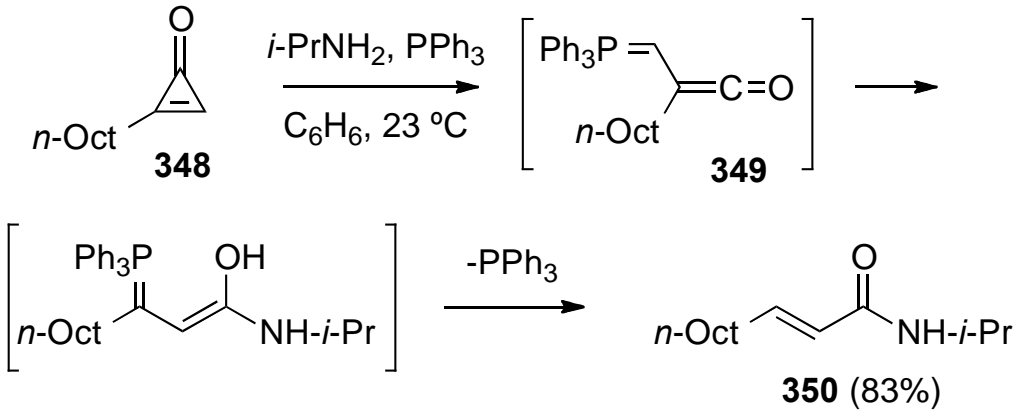

Scheme 122. Ketene generation by cyclopropenone ring opening.

$n$-Octylketene (352), generated by alkynyl ether (351) thermolysis in a flow reactor, was trapped by benzylamine giving amide $\mathbf{3 5 3}$ (Scheme 123). ${ }^{170}$

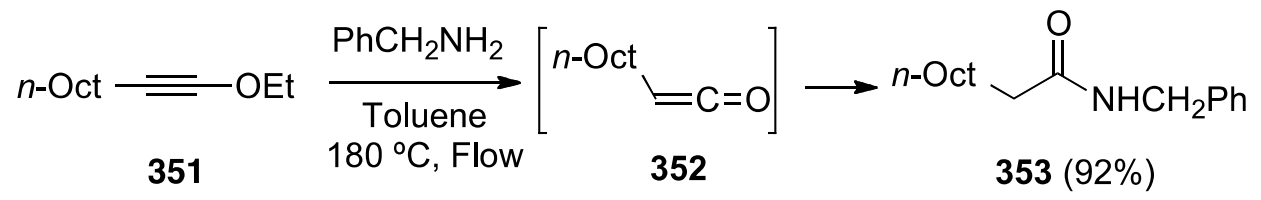

Scheme 123. Ketene formation from alkynyl ether thermolysis. 
Acyl ketene 355 generated by thermolysis of the acyl ester 354 underwent cyclization by intramolecular ketene amination to give the lactam 356, establishing the stereochemistry of the taumycin natural product (Scheme 124). ${ }^{171}$

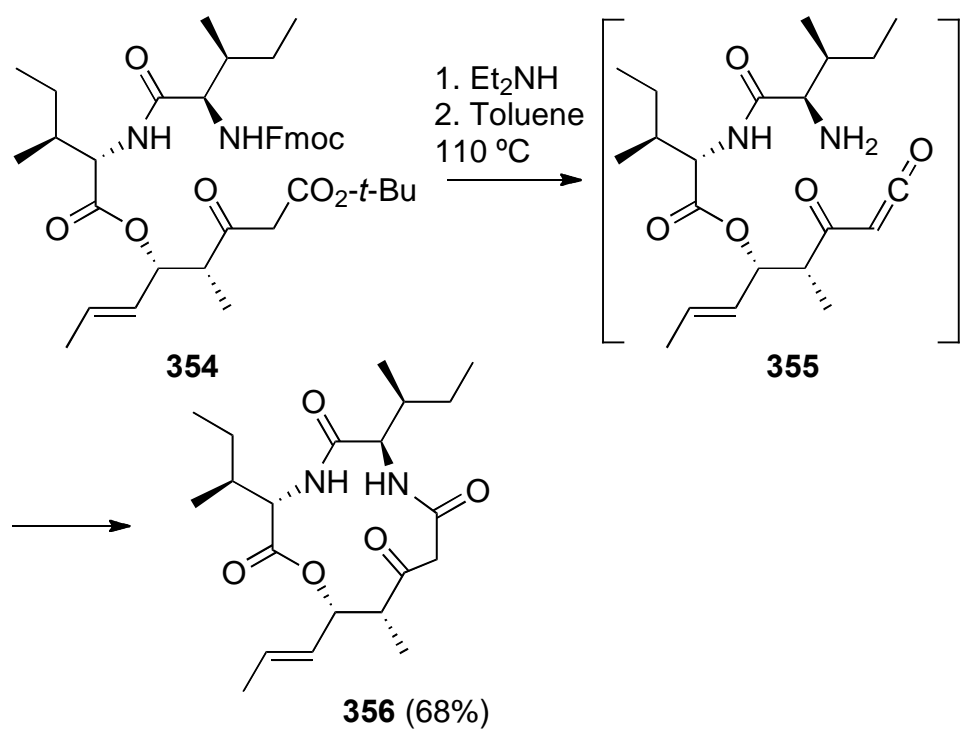

Scheme 124. Ketene generation by ester elimination with subsequent cyclization.

Acetylketene 113 generated by thermolysis of the dioxinone 358 reacts with the aminoaryl podand 357 to form acetoacetanilide podand 359 (Scheme 125). ${ }^{172}$ Such acetoacetanilidecontaining podands were then used in the Biginelli reaction as $\mathrm{CH}$-active components.

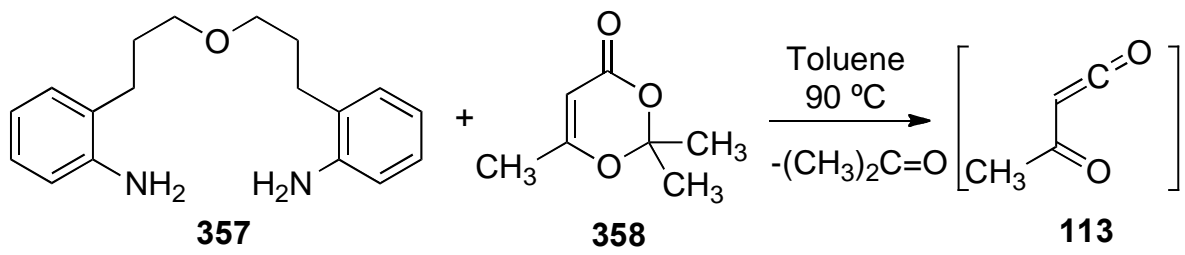<smiles>CC(=O)CC(=O)Nc1ccccc1OCCOCCOc1ccccc1NC(=O)CC(C)=O</smiles>

Scheme 125. Ketene formation by dioxinone thermolysis and double acylation.

Ketene generation from malonic acid is applied to the $N$-acylation of a variety of peptides, as well as in the formation of the resin-bound amide $\mathbf{3 6 0}$ (Scheme 126). ${ }^{173}$ The ketene 
intermediate was detected in situ by the ${ }^{1} \mathrm{H}$ NMR absorption at $2.6 \mathrm{ppm}$ during the reaction of the peptide of 2-Boc-ethylamine $\left(t-\mathrm{BuO}_{2} \mathrm{CCH}_{2} \mathrm{CH}_{2} \mathrm{NH}_{2}\right)$, and DFT studies support the proposed mechanism.

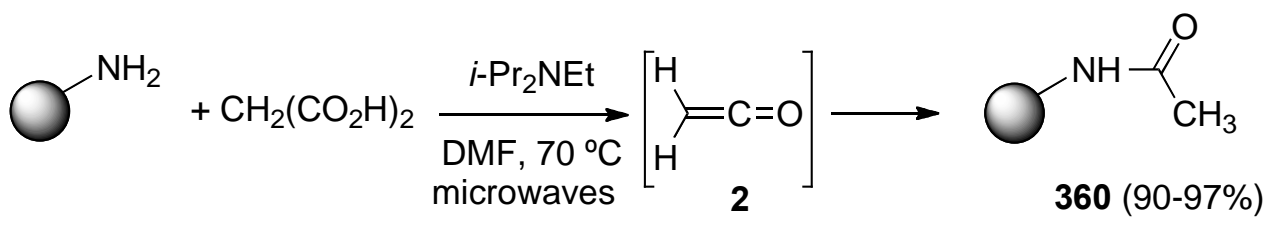

Scheme 126. Ketene generation from malonic acid and peptide acylation.

\subsection{Addition of carbon nucleophiles}

Ketenes including 159 generated by Wolff rearrangement in the presence of an isocyanide and a carboxylic acid undergo stereoselective formation of (Z)-acyloxyacrylamides $\mathbf{3 6 2}$ by initial attack of the isocyanide giving a zwitterionic intermediate 361 which is acylated forming the product (Scheme 127). ${ }^{174}$ Photoisomerization of the product alkenes was also observed, and this procedure was also successful with disubstituted ketenes. ${ }^{174}$

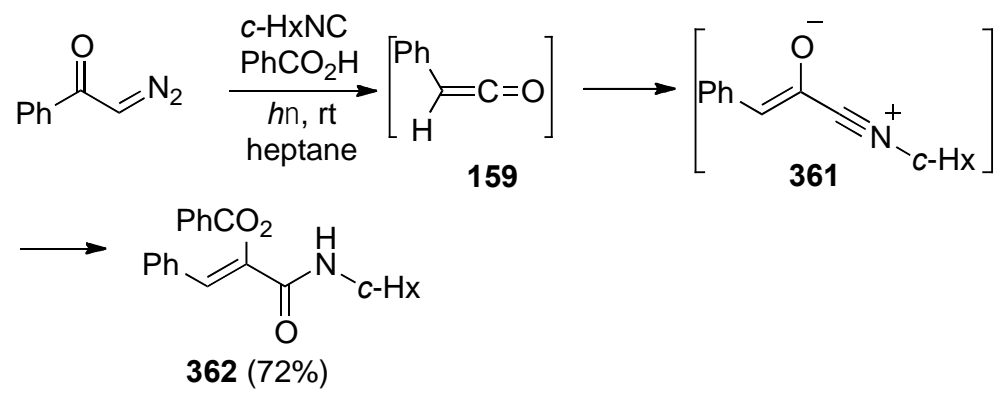

Scheme 127. Isocyanide addition to ketenes.

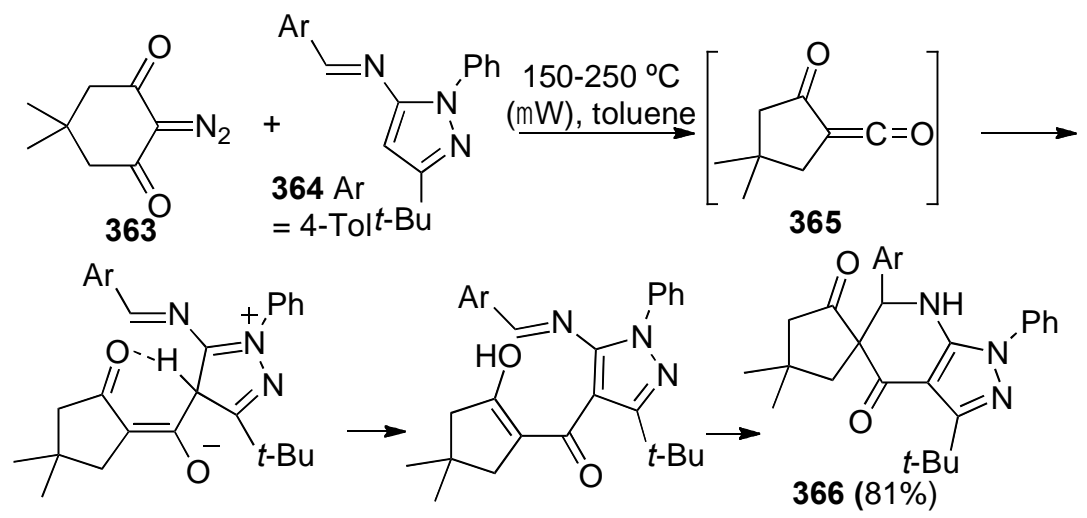

Scheme 128. Acylketene reaction with a carbon nucleophile and spiro-dihydropyridin-4-one formation. 
Ketene 365 from thermolysis of diazo ketone 363 reacts with the iminopyrazole 364 by spiro-cyclization proposed to involve Friedel-Crafts type addition followed by hydrogen transfer and intramolecular cyclization leading to 366 (Scheme 128), as supported by computational studies. ${ }^{175}$ The calculated transition state for the hydrogen transfer is shown in Figure 13. ${ }^{175}$

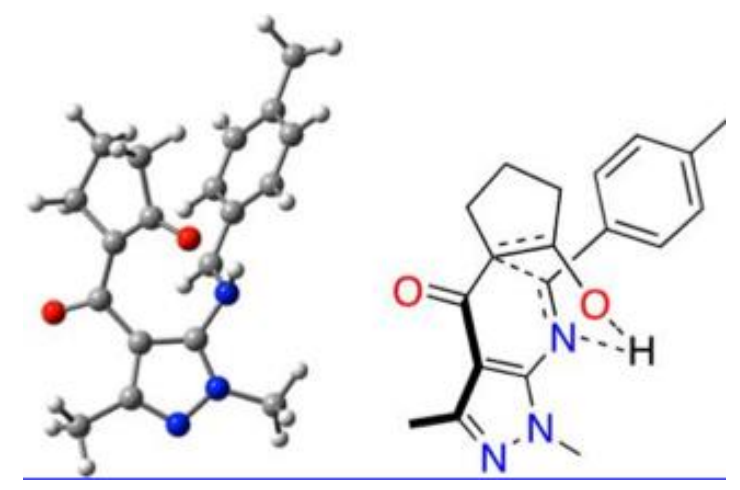

Figure 13. Calculated transition state for hydrogen transfer. (Reprinted with permission from the American Chemical Society ${ }^{175}$ ).

Phosphonate 367 reacts with ketenes by the Horner-Wadsworth-Emmons reaction forming trisubstituted allenes 368 in high yield (Scheme 129). ${ }^{176}$

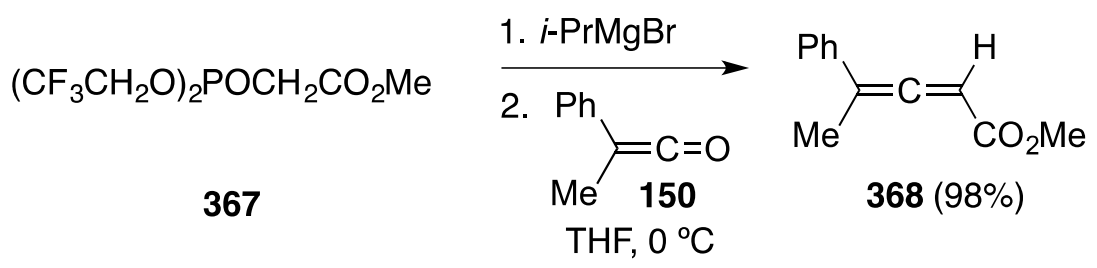

Scheme 129. Horner-Wadsworth-Emmons ketene to allene transformation.

Diphenylketene reacts with the ruthenium(0) complex 314 by addition to the dienyl grouping to form 315 (Scheme 130). ${ }^{177}$

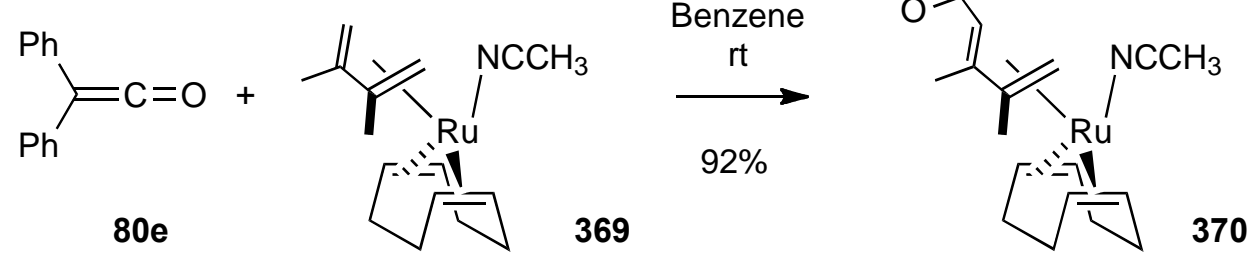

Scheme 130. Diphenylketene reaction with a dienyl ruthenium complex. 
Intramolecular $C$-acylation of enamine carbon by a ketene component (Scheme 104), and similar intramolecular acylation of a phenoxy substituent (Scheme 105), have been noted earlier. (Section 4.7)

\section{Electrophilic Additions to Ketenes}

Carbon-protonated ketene, the acetyl cation, is formed from methyl acetate or acetone in a pulsed discharge as the most stable product, while oxygen protonated ketene, formed only from acetone as a minor component, is formed as the next most stable ion. ${ }^{178}$ The energies of six isomeric structures of protonated ketene are reported there (Figure 14).

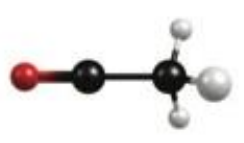

(a) $0.0 \mathrm{~kJ} / \mathrm{mol}$

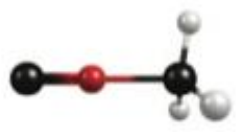

(d) +255.1

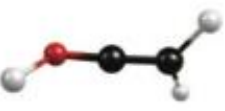

(b) $\quad+196.1$

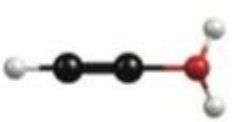

(e) $\quad+350.9$

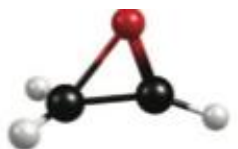

(c) $\quad+243.8$

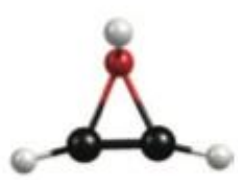

(f) $\quad+359.6$

Figure 14. Relative calculated energies $(\mathrm{kJ} / \mathrm{mol})$ of 6 isomers of protonated ketene (Reproduced from reference 179 with permission of the publisher)

Protonation of the ketene complex $\left.371\left(\left[\mathrm{Mo}_{2} \mathrm{Cp}_{2}\{\mu-\mathrm{C}(\mathrm{Ph}) \mathrm{CO})\right\}(\mu-\mathrm{PCy})_{2}(\mathrm{CO})_{2}\right]\right)$ gave the metal complex 372 in $88 \%$ yield as a red solid, and was interpreted as involving protonation on oxygen (Scheme 131). ${ }^{179,180}$ The structure of $\mathbf{3 7 2}$ was confirmed by an X-ray determination. ${ }^{180}$

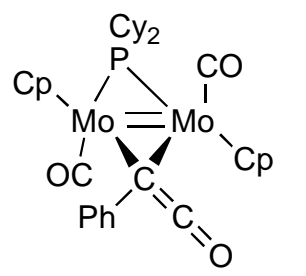

371 (IR $1993 \mathrm{~cm}^{-1}$ )

$\mathrm{Cp}=\mathrm{C}_{5} \mathrm{H}_{5}, \mathrm{Cy}=$ cyclohexyl
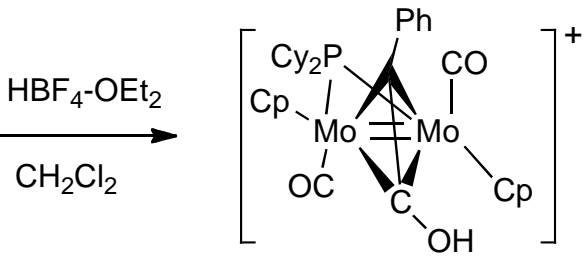

$372(88 \%)$

Scheme 131. Protonation of a molybdenum ketene complex. 
Catalytic asymmetric fluorination of ketene 373 occurs with the catalyst (-) -PPY and $N$ fluorodibenzenesulfonimide (NFSI) as the fluorine source (Scheme 132). The reaction is proposed to occur by complexation with the catalyst and then fluorine transfer. ${ }^{181}$
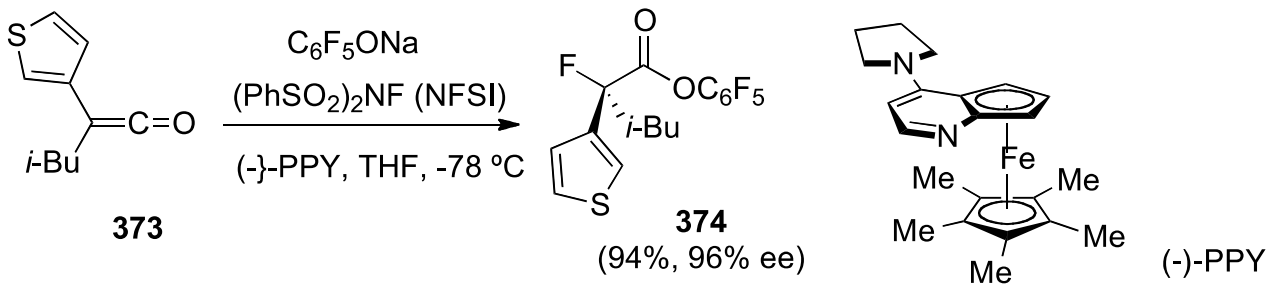

Scheme 132. Catalytic asymmetric fluorination.

\section{Conclusions}

The distinctive bonding in ketenes and the great utility of these materials have attracted the attention of talented investigators for more than a century. Remarkable achievements have been reported in the formation of ketenes by oxidation processes, reactions of ketene radical cations, unusual new ketenes, and organometallic ketenes The outstanding creativity shown by investigators, and the continued success that has been reported, indicates that there will be continued progress in the future.

\section{Acknowledgements}

Professor Melvin Newman provided the inspiration for our studies of ketenes, as described above. Facilities provided by the University of Toronto made the preparation of this review possible.

\section{References}

1. Newman, M. S.; Arkell, A.; Fukunaga, T. J. Am. Chem. Soc. 1960, 82, 2498. http://dx. doi.org/10.1021/ja01495a025

2. Allen, A. D.; Tidwell, T. T. J. Am. Chem. Soc. 1987, 109, 2774-2780. http://dx. doi.org/10.1021/ja00243a034

3. Fu, N.; Tidwell, T. T. Org. Reactions. 2015, 87, 2, 1-250. http://dx. doi.org/10.1002/0471264180.or087.02

4. Heravi, M. M.; Talaei, B. Adv. Heterocyclic Chem. 2014, 113, 143-244.

5. Heravi, M. M.; Talaei, B. Adv. Heterocyclic Chem. 2015, 114, 147-225. http://dx. doi.org/10.1016/B978-0-12-800170-7.00004-3 
6. Candeias, N. R.; Trindade, A. F.; Gois, P. M. P.; Afonso, C. A. M. Comp. Org. Synth. (2nd Ed.) Knochel, P.; Molander, G. A.; Eds. 2014, 3, 944-991.

http://dx. doi.org/10.1016/B978-0-08-097742-3.00325-6

7. Robiette, R.; Marchand-Brynaert, J. Comp. Org. Synth. (2nd Ed.) Knochel, P.; Molander, G. A.; Eds. 2014, 5, 85-128. http://dx. doi.org/10.1016/B978-0-08-097742-3.00325-6

8. Alcaide, B.; Aragoncillo, C.; Almendros, P. Comp. Org. Synth. (2nd Ed.) Knochel, P.; Molander, G. A.; Eds. 2014, 5, 66-84. http://dx. doi.org/10.1016/B978-0-08-097742-3.00502-4

9. Allen, A. D.; Tidwell, T. T. Adv. Phys. Org. Chem. 2014, 48, 229-324. http://dx. doi.org/10.1016/B978-0-12-800256-8.00004-7

10. Miller, R.; Abaecherli, C.; Said, A.; Jackson, B. "Ketenes" Ullmann's Fine Chemicals, Elvers, B., Ed. 2014, 2, 801-815. http://dx. doi.org/10.1002/14356007

11. Tidwell, T. T. Topics Heterocyclic Chem. 2013, 30, 111-146. http://dx.doi.org/10.1007/7081_2012_89

12. Allen, A. D.; Tidwell, T. T. Chem. Revs. 2013, 113, 7287-7342. http://dx.doi.org/10.1021/cr3005263

13. Danheiser, R. L., Ed. Science of Synthesis (Houben-Weyl). Vol. 23, Stuttgart: Georg Thieme Verlag. 2006. http://dx. doi.org/10.1055/sos-SD-023-00001

14. Tidwell, T. T. Ketenes, $2^{\text {nd }}$ Ed. 2006, John Wiley, New York. http://dx.doi/10.1002/0471767670

15. Ford, A.; Miel, H.; Ring, A.; Slattery, C. N.; Maguire, A. R.; McKervey, M. A. Chem. Rev. 2015, 115, 9981-10080. http://dx. doi.org/10.1021/acs.chemrev.5b00121

16. Gorinchoy, N. Chem. J. Moldova 2014, 9, 80-89.

17. Wang, K.; Meng, J.; Liu, Y., Sun, J. J. Phys. B: At. Mol. Opt. Phys. 2015 48, 155202. http://dx. doi.org/10.1088/0953-4075/48/15/155202

18. Rauhut, G. J. Phys. Chem. A 2015, 119, 10264-10271. http://dx.doi.org/10.1021/acs.jpca.5b06922

19. Bierkandt, T.; Kasper, T.; Akyildiz, E.; Lucassen, P; Osswald, A.; Köhler, M.; Hemberger, P. Proc. Combust. Inst. 2015, 35, 803-811. http://dx. doi.org/10.1016/j.proci.2014.05.094

20. Najafian, K.; Schleyer, P. v. R.; Tidwell, T. T. Org. Biomol. Chem. 2003, 1, 3410-3417. http://dx. doi.org/DOI/10.1039/B304718K

21. Brown, R. D.; Brown, R. F. C.; Eastwood, F. W.; Godfrey, P. D.; McNaughton, D. J. Am. Chem. Soc. 1979, 101, 4705-4708.

http://dx.doi.org/10.1021/ja00510a045 
22. Allen, A. D.; Cheng, B.; Fenwick, M. H.; Huang, W.; Missiha, S.; Tahmassebi, D.;

Tidwell, T. T. Org. Lett. 1999, 1, 693-696.

http://dx.doi.org/10.1021/o1990628i

23. Clark, J. M.; Nimlos, M. R.; Robichaud, D. J. J. Phys. Chem. A 2014, 118, 260-274. http://dx.doi.org/10.1021/jp4095485

24. McAllister, M. A.; Tidwell, T. T. Can. J. Chem. 1994, 72, 882-887.

http://dx.doi.org/10.1139/v94-115

25. Balucani, N.; Leonori, F.; Casavecchia, P.; Fu, B.; Bowman, J. M. J. Phys. Chem. A 2015, 119, 12498-12511.

http://dx.doi.org/10.1021/acs.jpca.5b07979

26. Liu, D. Science China Tech. Sci. 2015, 58, 1696-1704.

http://dx.doi.org/10.1007/s11431-015-5884-2

27. Pham, M. D.; Lin, Y.-P; Quan, V. V.; Nagababu, P.; Chang, B. T.-A.; Ng, K. Y.; Chen, C.H.; Han, C.-C.; Chen, C.-H.; Li, M. S.; Yu, S. S.-F; Chan, S. I. Biochim. Biophys. Acta, Proteins Proteomics 2015, 1854, 1842-1852.

http://dx.doi.org/10.1016/j.bbapap.2015.08.004

28. Boganov, S. E.; Kudryashov, S. V.; Ryabov, A. Yu.; Suslov, A. I.; Rynin, S. S.; Egorov, M. P.; Nefedov, O. M. Plasma Chem. Plasma Proc. 2014, 34, 1345-1370. http://dx.doi.org/10.1007/s11090-014-9576-7

29. Agündez, M.; Cernicharo, J.; Guelin, M. Astron. Astrophysics 2015, 577, L5, 1-6. http://dx.doi.org/10.1051/0004-6361/201526317

30. Wakelam, V.; Loison, J.-C.; Hickson, K. M.; Ruaud, M. MNRAS Letters 2015, 453, L48L52.

http://dx.doi.org/10.1093/mnrasl/slv097

31. Agündez, M.; Wakelam, V. Chem. Revs. 2013, 113, 8710-8730.

http://dx.doi.org/10.1021/cr4001176

32. Jones, W. P.; Jurisch, M.; Marquis, A. J. Flow, Turbulence, Combustion 2015, 95, 519538.

http://dx.doi.org/10.1007/s10494-015-9637-x

33. Parker, D. S. N.; Kaiser, R. I.; Troy, T. P.; Kostko, O.; Ahmed, M.; Mebel, A. M. J. Phys. Chem. A 2015, 119, 7145-7154.

http://dx.doi.org/10.1021/jp509170x

34. Jang, S.-C., Choi, J.-H. Phys. Chem. Chem. Phys. 2014, 16, 23679-23685. http://dx.doi.org/ 10.1039/C4CP03046J

35. Jung, S.-H.; Jang, S.-C.; Kim, J.; Kim, J.-W.; Choi, J.-H. J. Phys. Chem. A 2015, 119 , 11761-11771. http://dx.doi.org/10.1021/acs.jpca.5b09191

36. Peng, Z.; McLuckey, S. A. Int. J. Mass Spectrometry 2015, 391, 17-23. http://dx.doi.org//10.1016/j.ijms.2015.07.027

37. Gai, S.; Zhang, Q.; Hu, X. J. Org. Chem. 2014, 79, 2111-2114. 
http://dx.doi.org/10.1021/jo4028177

38. Yan, X.; Hu, X. J. Org. Chem. 2014, 79, 5282-5286.

http://dx.doi.org/10.1021/jo5008652

39. Stalling, T.; Harker, W. R. R.; Auvinet, A.-L.; Cornel, E. J.; Harrity, J. P. A. Eur. J. Org. Chem. 2015, 21, 2701-2704.

http://dx.doi.org/10.1002/chem.201405863

40. Chen, P.-H.; Sieber, J.; Senanayake, C. H.; Dong, G. Chem. Sci. 2015, 6, 5440-5445. http://dx.doi.org/10.1039/c5sc01875g

41. Yamamoto, Y.; Kurohara, T.; Shibuya, M. Chem. Commun. 2015, 51, 16357-16360. http://dx.doi.org/10.1039/C5CC06920C

42. Ladinig, M.; Ramseier, M.; Wirz, J. Photochem. Photobiol. A 2015, 91, 678. http://dx.doi.org/10.1111/php.12341

43. Liu, H.-J.; Ziegler, M. S.; Tilley, T. D. Angew. Chem., Int. Ed. 2015, 54, 6622. http://dx.doi.org/10.1002/anie.201502156

44. Acton, A. W.; Allen, A. D.; Antunes, L. M.; Fedorov, A. V., Najafian, K.; Tidwell, T. T.; Wagner, B. D. J. Am. Chem. Soc. 2002, 124, 13790. http://dx.doi.org/10.1021/ja027347h

45. Islami, M. R.; Allen, A. D.; Vukovic, S.; Tidwell, T. T. Org. Lett. 2011, 12, 494-497. http://dx.doi.org/10.1021/o1102837n

46. Allen, A. D.; Fedorov, A. V.; Fu, N.; Kobayashi, S.; Tidwell, T. T.; Vukovic, S.; Badal, M. M. R.; Mishima, M. Can. J. Chem. 2014, 92, 1119-1130. http://dx.doi.org/10.1139/cjc-2014-0208

47. Wright, E. M.; Warner, B. J.; Foreman, H. E.; McCunn, L. R.; Urness, K. N. J. Phys. Chem. A 2015, 119, 7966-7972. http://dx.doi.org/10.1021/acs.jpca.5b04565

48. Yadav, C. H.; Murugan, P. Int. J. ChemTech Res. 2015, 8, 860-869.

49. Froebel, S.; Buschhaus, L.; Villnow, T.; Weingart, O.; Gilch, P. Phys. Chem. Chem. Phys. 2015, 17, 376-386. http://dx.doi.org/10.1039/C4CP03351E

50. Murdock, D.; Harris, S. J.; Luke, J.; Grubb, M. P.; Orr-Ewing, A. J.; Ashfold, M. N. R. Phys. Chem. Chem. Phys. 2014, 16, 21271-21279. http://dx.doi.org/10.1039/C4CP03653K

51. Cao, J. J. Chem. Phys. 2015, 142, 244302/1-244302/11. http://dx.doi.org/10.1063/1.4922742

52. Krupa, J.; Wierzejewska, M. Chem. Phys. Lett. 2015, 618, 219-224. http://dx.doi.org/10.1016/j.cplett.2014.11.02

53. Kuş, N.; Sagdinc, S.; Fausto, R. J. Phys. Chem. A 2015, 119, 6296-6308. http://dx.doi.org/DOI/10.1021/acs.jpca.5b03942

54. Maity, S.; Kaiser; R. I.; M. Jones, B. M. Phys. Chem. Chem. Phys. 2015, 17, 3081-3114. http://dx.doi.org/10.1039/C4CP04149F 
55. Nguyen, S. C.; Lomont, J. P.; Zoerb, M. C.; Pham, P. V.; Cahoon, J. F.; Harris, C. P. Organometallics 2014, 33, 6149-6153.

http://dx.doi.org/10.1021/om500795b

56. McMahon, S.; Amirjalayer, S.; Buma, W. J.; Halpin, Y.; Long, C.; Rooney, A. D.;

Woutersen, S.; Pryce, M. T. Dalton Trans. 2015, 44, 15424-15434.

http://dx.doi.org/10.1039/C5DT01568E

57. Ramalakshmi, R.; Mondal, B.; Bhattacharyya, M.; Varghese, B.; Ghosh, S. J. Organomet. Chem. 2015, 798, 106-111. http://dx.doi.org/1016/j.cattod.2015.03.033

58. Majumdar, M.; Omlor, I.; Yildiz, C. B.; Azizoglu, A.; Huch, V.; Scheschkewitz, D. Angew. Chem. Int. Ed. 2015, 54, 8746-8750.

http://dx.doi.org/10.1002/anie.201503455

59. Lungu, D.; Birzoi, R. M.; Goers, C.; Bartsch, R.; du Mont, W.-W.; Daniliuc, C.; Jones, P. G. Eur. J. Inorg. Chem. 2016, 700-708. http://dx.doi.org/10.1002/ejic.201500817

60. Ke, X.-N.; Schienebeck, C. M.; Zhou, C.-C.; Xu, X.-F.; Tang, W.-P. Chinese Chem. Lett. 2015, 26, 730-734. http://dx.doi.org/10.1016/j.cclet.2015.03.016

61. de Jong, K. P. Science 2016, 351, 1030-1031. http://dx.doi.org/10.1162/science.aaf325

62. Jiao, F.; Li, J.; Pan, X.; Xiao, J.; Li, H.; Ma, H.; Wei, M.; Pan, Y.; Zhou, Z.; Li, M; Miao, S.; Li, J.; Zhu, Y.; Xiao, D.; He, T.; Yang, J.; Qi, F.; Fu, Q.; Bao, X. Science. 2016, 351, 1065-1068.

http://dx.doi.org/10.1126/science.aaf1835

63. Ge, F.; Kehr, G.; Daniliuc, C. G.; Erker, G. Organometallics 2015, 34, 229-235. http://dx.doi.org/10.1021/om501085j

64. Tollár, G.; Kégl, T. J. Inorg. Chem. 2013, 52, Article ID 149425. http://dx.doi.org/10.1155/2013/149425

65. Neitzel, A.; Lykhach, Y.; Johanek, V.; Tsud, N. Skala, T.; Prince, K. C.; Matolin, V.; Libuda, J. J. Phys. Chem. C 2014, 118, 14316-14325. http://dx.doi.org/10.1021/jp502017t

66. Calaza, F. C.; Chen, T.-L.; Mullins, D. R.; Xu, Y.; Overbury, S. H. Catalysis Today 2015, $253,65-76$.

http://dx.doi.org/10.1016/j.cattod.2015.03.033

67. Clark, J. M.; Nimlos, M. R.; Robichaud, D. J. J. Phys. Chem. A 2014, 118, 260-274. http://dx.doi.org/10.1021/jp4095485

68. Würmel, J.; Simmie, J. M.; Losty, M. M.; McKenna, C. D. J. Phys. Chem. A, 2015, 119, 6919-6927. http://dx.doi.org/10.1021/acs.jpca.5b04435

69. Behzadi, M.; Saidi, K.; Islami, M. R.; Khabazzadeh, H. J. Chem. Sci. 2016, 128, 111-117. 
http://dx.doi.org/10.1007/s12039-015-1007-7

70. Plüg, C; Kanaani, C. P. H.; Wentrup, C. Aust. J. Chem. 2015, 68, 687-692. http://dx.doi.org/10.1071/CH1471416

71. Matsubara, T., Ueta, C. J. Phys. Chem. A 2014, 118, 8664-8675. http://dx.doi.org/10.1021/jp504392p

72. Hoffmeister, L.; Fukuda, T.; Pototschnig, G., Fürstner, A. Chem. Eur. J. 2015, 21, 45294533.

http://dx.doi.org/10.1002/chem.201500437

73. Tanaka, N. Open J. Phys. Chem. 2014, 4, 117-125. http://dx.doi.org/10.4236/ojpc.2014.43014

74. Tanaka, N.; Nakamura, K.; Yutaka, M.; Nishikiori, H. Chem. Phys. Lett. 2014, 613, 34-39. http://dx.doi.org/10.1016/j.cplett.2014.08.053

75. Peng, B.; Zhao, C.; Kasakov, S.; Foraita, S.; J. Lercher, A. Chem. Eur. J. 2013, 19, 47324741 .

http://dx.doi.org/10.1002/chem.201203110

76. Foraita, S.: Fulton, J. L.; Chase, Z. A.; Vjunov, A.; Xu, P.; Baráth, E.; Camaioni, D. M.;

Zhao, C.; Lercher, J. A. Chem. Eur. J. 2015, 21, 2423-2434.

http://dx.doi.org/10.1002/chem.201405312

77. McEntee, M.; Tang, W.; Neurock, M.; Yates, J. T. Jr. ACS Catal. 2015, 5, 744-753. http://dx.doi.org/10.1021/cs5014255

78. Cookson, R.; Barrett, T. N.; Barrett, A. G. M. Acc. Chem. Res. 2015, 48, 628-642. http://dx.doi.org/10.1021/ar5004169

79. Navarro, I.; Basset, J.-F.; Hebbe, S.; Major, S. M.; Werner, T.; Howsham, C.; Brackow, J.; Barrett, A. G. M. J. Am. Chem. Soc. 2008, 130, 10293-10298. http://dx.doi.org/10.1021/ja803445u

80. Wang, C.; Kong, Y.; Qiao. H. Arkivoc 2015, (vii), 92-100. http://dx.doi.org/10.3998/ark.5550190.p009.162

81. Gündüz, H.; Kumbaraci, V.; Talinli, N. Helv. Chim. Acta 2014, 97, 1097-1106. http://dx.doi.org/10.1002/hlca.201300391

82. Ahmar, S.; Fillion, E. Org. Lett. 2014, 16, 5748-5751. http://dx.doi.org/10.1021/ol502811j

83. Zhang, W.; Ready, J. M. Angew. Chem. Int. Ed. 2014, 53, 8980-8984. http://dx.doi.org/10.1002/anie.201405036

84. Henry, C.; Bolien, D.; Ibanescu, B.; Bloodworth, S.; Harrowven, D. C.; Zhang, X.; Craven, A.; Sneddon, H. F.; Whitby, R. J. Eur. J. Org. Chem. 2015, 1491-1499. http://dx.doi.org/10.1002/ejoc.201403603

85. Robb, M. J.; Moore, J. S. J. Am. Chem. Soc. 2015, 137, 10946-10949. http://dx.doi.org/10.1021/jacs.5b07345

86. Kung, H.; Teplyakov, A. J. Catalysis 2015, 330, 145-153. http://dx.doi.org/10.1016/j.jcat.2015.07.021 
87. Jaber, A. A.; Ceccarelli, C.; Kahane, C.; Caux, E. Astrophys. J. 2014, 791, 29/1-29/6. http://dx.doi.org/10.1088/0004-637X/791/1/29

88. Atkinson, S. J.; Noble-Eddy, R.; Masters, S. L. J. Phys. Chem. A 2016, 120, 2041-2048. http://dx.doi.org/10.1021/acs.jpca.6b00704

89. Ibrahim, A. A.; Nalla, D.; Van Raaphorst, M.; Kerrigan, N. J. J. Am. Chem. Soc. 2012, $134,2942-2945$. http://dx.doi.org/10.1021/ja211678m

90. Chen, S.; Ibrahim, A. A.; Mondal, M.; Magee, A. J.; Cruz, A. J.; Wheeler, K. A.; Kerrigan, N. J. Org. Lett. 2015, 17, 3248-3251. http://dx.doi.org/10.1021/acs.orglett.5b01391

91. Rullière, P.; Carret, S.; Milet, A.; Poisson, J.-F. Chem. Eur. J. 2015, 21, 3876-3881. http://dx.doi.org/10.1002/chem.201405393

92. Rasik; C. M.; Brown, M. K. Angew. Chem. Int. Ed. 2014, 53, 14522-14526. http://dx.doi.org/10.1002/anie.201408055

93. Matsubara, T.; Ishihara, J.; Hatakeyama, S. Heterocycles 2015, 90, 405-424. http://dx.doi.org/10.3987/COM-14-S(K)32

94. Wang, Y.; Wei, D.; Li, Z.; Zhu, Y.; Tang, M. J. Phys. Chem. A 2014, 118, 4288-4300. http://dx.doi.org/10.1021/jp500358m

95. Rasik, C. M.; Hong, Y. J.: Tantillo, D. J.; Brown, M. K. Org. Lett. 2014, 16, 5168-5171. http://dx.doi.org/10.1021/o15025184

96. Wang, Y.; Zheng, Z.; Zhang, L. Angew. Chem. Int. Ed. 2014, 53, 9572 -9576. http://dx.doi.org/10.1002/anie.201403796

97. Ryabukhin, S. V.; Fominova, K. I.; Sibgatulin, D. A.; Grygorenko, O. O. Tetrahedron Lett. 2014, 55, 7240-7242. http://dx.doi.org/10.1016/j.tetlet.2014.11.050

98. Lachia, M.; Dakas, P.-Y.; De Mesmaeker, A. Tetrahedron Lett. 2014, 55, 6577-6581. http://dx.doi.org/10.1016/j.tetlet.2014.10.040

99. Erden, I.; Watson, S. E. Tetrahedron Lett. 2016, 57, 237-238. http://dx.doi.org/10.1016/j.tetlet.2015.12.043

100. Willumstad, T. P.; Boudreau, P. D.; Danheiser, R. L. J. Org. Chem. 2015, 80, 1179411805 . http://dx.doi.org/10.1021/acs.joc.5b01648

101. Minami, Y.; Hiyama, T. Acc. Chem. Res. 2016, 49, 67-77. http://dx.doi.org/acs.accounts.5b00414.

102. Mondal, M.; Chen, S.; Othman, N.; Wheeler, K.; Kerrigan, N. J. J. Org. Chem. 2015, 80, 5789-5794. http://dx.doi.org/10.1021/acs.joc.5b00869

103. Chen, S.; Mondal, M.; Adams, M. P.; Wheeler, K. A.; Kerrigan, N. J. Tetrahedron Lett. 2015, 56, 6421-6424. http://dx.doi.org/10.1016/j.tetlet.2015.09.141 
104. Jumde, R. P.; Di Pietro, A.; Manariti, A.; Mandoli, A. Chem. Asian J. 2015, 10, 397-404. http://dx.doi.org/10.1002/asia.201402924

105. Douglas, J. J.; Churchill, G.; Slawin, A. M. Z.; Fox, D. J.; Smith, A. D. Chem. Eur. J. 2015, 21,16354-16358. http://dx.doi.org/10.1002/chem.201503308

106. Singh, G. S.; Sudheesh, S. Arkivoc 2014, (i) 337-385. http://dx.doi.org/10.3998/ark.5550190.0015.100

107. Banik, B. K. J. Indian Chem. Soc. 2014, 91, 1837-1860.

108. de Bruin, B.; Tang, Z.; Mandal, S.; Paul, N. D.; Lutz, M.; Li, P.; van der Vlugt, J. I. Org. Chem. Front., 2015, 2, 1561-1577. http://dx. doi.org/10.1039/c5qo00287g

109. Zhang, H.-M.; Gao, Z.-H.; Ye, S. Org. Lett. 2014, 16, 3079-3081. http://dx. doi.org/10.1021/o1501205v

110. Zheng, R.; Wang, Y.; Zhang, L. Tetrahedron Lett. 2015, 56, 3144-3146. http://dx. doi.org/10.1016/j.tetlet.2014.11.138

111. Hafner, A.; Ley, S. V. Synlett 2015, 1470-1474. http://dx. doi.org/10.1055/s-0034-1380679

112. Zarei, M. Tetrahedron Lett. 2014, 55, 5354-5357. http://dx. doi.org/10.1016/j.tetlet.2014.07.089

113. Berber, N.; Arslan, M.; Bilen, C.; Sackes, Z.; Gencer, N.; Arslan, O. Russ. J. Bioorg. Chem. 2015, 41, 414-420. http://dx. doi.org/10.1134/S1068162015040111

114. Jarrahpour, A.; Heiran, R. J. Iran. Chem. Soc. 2014, 11, 75-83. http://dx. doi.org/10.1007/s13738-013-0277-6

115. Jarrahpour, A.; Ebrahimi, E.; Sinou, V.; Latour, C.; Brunel, J. M. Eur. J. Med. Chem. 2014, 87, 364-371. http://dx.doi.org/10.1016/j.ejmech.2014.09.077

116. Jarrahpour, A.; Shirvani, P.; Sinou, V.; Latour, C.; Brunel, J. M. Med. Chem. Res. 2016, $25,149-162$. http://dx.doi.org/10.1007/s00044-015-1474-x

117. Jarrahpour, A.; Nazari, M. Iran. J. Sci. Tech., Trans. A: Science 2015, 39, 259-265. http://ijsts.shirazu.ac.ir

118. Behzadi, M.; Saidi, K.; Islami, M. R.; Khabazzadeh, H. J. Chem. Sci. 2016, 128, 111-117. http://dx. doi.org/10.1007/s12039-015-1007-7

119. Hosseinkhani, B.; Islami, M. R.; Hosseinkhani, S. Synlett 2015, 2277-2279. http://dx.doi.org/10.1055/s-0035-1560066

120. Mortazavi, Z. F. A.; Islami, M. R.; Khaleghi, M. Org. Lett. 2015, 17, 3034-3037. http://dx. doi.org/10.1021/acs.orglett.5b01309

121. Huang, Z. ; Wang, C. ; Tokunaga, E. ; Shibata, N. Org. Lett. 2015, 17, 56105613. http://dx. doi.org/10.1021/acs. orglett.5b02827 
122. Hans, M.; Wouters, J.; Demonceau, A.; Delaude, L. Chem. Eur. J. 2015, 21, 10870-10877. http://dx. doi.org/10.1002/chem.201501060

123. Stoll, T. Alker, A.; Kolczewski, S.; Menzi, A.; Revil-Baudard, V.; Tetrahedron Lett. 2015, $56,772-774$.

http://dx.doi.org/10.1016/j.tetlet.2014.12.017

124. Sharma, P.; Ahuja, M.; Kumar, A.; Sahu. V. Chem. Phys. Lett. 2015 628, 85-90. http://dx.doi.org/10.1016/j.cplett.2015.04.005

125. Santoro, S.; Liao, R.-Z.; Marcelli, T.; Hammar, P.; Himo, F. J. Org. Chem. 2015, 80, 26492660.

http://dx.doi.org/10.1021/jo502838p

126. Karlsson, S.; Bergman, R.; Löfberg, C; Moore, P.; Ponten, F.; Tholander, J.; Sörensen, H. Org. Proc. Res. Dev. 2015, 19, 2067-2074. http://dx.doi.org/10.1021/acs.oprd.5b00319

127. Domingo, L. R.; Sáez, J. A. RSC Adv. 2014, 4, 58559-58566. http://dx.doi.org/10.1039/C4RA10291F

128. Arumugam, N.; Almansour, A. I.; Kumar, R. S.; Rajesh, R.; Periyasami, G.; Raghunathan, R. Med. Chem. 2014, 10, 730-737. http://dx.doi.org/10.2174/1573406410666140226115258

129. Jetti, V.; Chidurala, P.; Pagadala, R.; Meshram, J. S.; Ramakrishna, C. J. Het. Chem. 2014, 51 (Suppl. 1) E183-E188. http://dx.doi.org/10.1002/jhet.1922

130. Li, X.; Jin, X.; Xu, J. J. Org. Chem. 2015, 80, 6976-6985. http://dx.doi.org/10.1021/acs.joc.5b00573

131. Bains, D.; Kumar, Y.; Singh, P.; Bhargava, G. J. Het. Chem. 2016, in press. http://dx.doi.org/10.1002/jhet.2465

132. Cho, J.; Irie, S.; Iwahashi, N.; Itoh, Y.; Saigo, K.; Ishida, Y. Tetrahedron Lett. 2015, 56, 127-131. http://dx.doi.org/10.1016/j.tetlet.2014.11.041

133. Boivin, J.; El Kaim, L.; Zard, S. Z. Tetrahedron 1995, 51, 2573-2584. http://dx.doi.org/0040-4020(95)00006-2

134. Rostovskii, N. V.; Novikov, M. S.; Khlebnikov, A. F.; Starova, G. L.; Avdontseva, M. S. Beilstein J. Org. Chem. 2015, 11, 302-312. http://dx.doi.org/10.3762/bjoc.11.35

135. Qiu, G.; Wu, J. Chemical Record 2016, 16, 19-34. http://dx.doi.org/10.1002/tcr.201500219

136. Liu, G.; Liu, H.; Qiu, G.; Pu, S.; Wu, J. Chem. Commun. 2012, 48, 7049. http://dx.doi.org/10.1039/C2CC33375A

137. Weyler, W. Jr., Duncan, W. G.; Liewen, M. B.; Moore, H. W. Org. Synth. 1976, 55, 32-38. http://dx.doi.org/10.15227/orgsyn.055.0032

138. Doana, M. I.; Danila, M.-G.; Draghici, C.; Filip, P. I. Revista Chim. 2015, 66, 1116-1121. 
139. Richmond, E.; Ling, K. B.; Duguet, N.; Manton, L. B.; Celebi-Olcum, N.; Lam, Y.-H.; Alsancak, S.; Slawin, A. M. Z.; Houk, K. N.; Smith, A. D. Org. Biomol. Chem. 2015, 13, 1807-1817. http://dx.doi.org/10.1039/C4OB02526A

140. Uhl, W.; Wegener, P.; Würthwein, E.-U. Zeit. Anorg. Allgem. Chem. 2015, 641, 21022108.

http://dx.doi.org/10.1002/zaac.201500519

141. Ahmed, I.; Tia, R.; Adei, E. J. Theo. Comp. Chem. 2015, 14, 1550035. http://dx.doi.org/10.1142/S0219633615500352

142. Ahmed, I.; Tia, R.; Adei, E. Inorg. Chim. Acta 2016, 441, 57-66. http://dx.doi.org/doi:10.1016/j.ica.2015.11.006

143. Makowiec, S.; Najda, E.; Janikowska, K. J. Het. Chem. 2015, 52, 205-210. http://dx.doi.org/10.1002/jhet.2028

144. Fuse, S.; Yoshida, H.; Oosumi, K.; Takahashi, T. Eur. J. Org. Chem. 2014, 4854-4860. http://dx.doi.org/10.1002/ejoc.201402478

145. Gupta, R.; Sharma, D.; Verma, P. S.; Jain, A. J. Het. Chem. 2016, 53, 38-45 http://dx.doi.org/10.1002/jhet.776

146. Chandrasekhar, S.; Kumar, H. V. Synth. Comm. 2015, 45, 232-235. http://dx.doi.org/10.1080/00397911.2014.960938

147. Seki, H.; Georg, G. I. Synlett 2014, 25, 2536-2557. http://dx.doi.org/10.1055/s-0034-1378529 pdf SL 20152536

148. Seki, H.; Georg, G. I. J. Am. Chem. Soc. 2010, 132, 15512-15513. http://dx.doi.org/10.1021/ja107329k

149. Seki, H.; Georg, G. I. Org. Lett. 2011, 13, 2147-2149. http://dx.doi.org/10.1021/o1200358h

150. Šimáček, A.; Hradilová, L.; Dvořáková, B.; Jedinák, L.; Bertolasi, V.; Hradil, P. Tetrahedron Lett. 2015, 56, 53-55. http://dx.doi.org/10.1016/j.tetlet.2014.09.061

151 Liu, Q.; Meng, J.; Liu, Y.; Yang, C.; Xia, W. J. Org. Chem. 2014, 79, 8143-8155. http://dx.doi.org/10.1021/jo5013465

152. Lopez, C. S.; Faza, O. N.; Freindorf, M.; Kraka, E.; Cremer, D. J. Org. Chem. 2016, 81, 404-414. http://dx.doi.org/10.1021/acs.joc.5b01997

153. Zahedifar, M.; Sheibani, H. Aust. J. Chem. 2014, 67, 1201-1204. http://dx.doi.org/10.1071/CH14095

154. Hao, X.; Lin, L.; Tan, F.; Yin, C.; Liu, X.; Feng, X. ACS Catal. 2015, 6052-6056. http://dx.doi.org/10.1021/acscatal.5b01719

155. Sun, L.; Liang, Z.; Ye, S. Acta Chim. Sinica 2014, 72, 841-844. http://dx.doi.org/10.6023/A14040334 
156. Frömel, S.; Radermacher, G.; Wibbeling, B.; Daniliuc, C. G.; Warren, T. H.; Kehr, G.; Erker, G. Israel J. Chem. 2015, 55, 210-215.

http://dx.doi.org/10.1002/ijch.201400133

157. Drège, E.; Venot, P.-E.; Le Bideau, T.; Retailleau, P.; Joseph, D. J. Org. Chem. 2015, 80, 10119-10126. http://dx. doi.org/10.1021/acs.joc.5b01727

158. Moazami, Y.; Pierce, J. G. Synthesis 2015, 3363-3370. http://dx. doi.org/10.1055/s-0034-1378788

159. Nguyen, T. L.; Xue, B. C.; Ellison, G. B.; Stanton, J. F. J. Phys. Chem. A 2013, 117, 10997-11005. http://dx. doi.org/10.1021/jp408337y

160. Louie, M. K.; Francisco, J. S.; Verdicchio, M.; Klippenstein, S. J.; Sinha, A. J. Phys. Chem. A 2015, 119, 4347-4357. http://dx. doi.org/10.1021/jp5076725

161. Kahan, T. F.; Ormond, T. K.; Ellison, G. B.; Vaida, V. Chem. Phys. Lett. 2013, 565, 1-4. http://dx. doi.org/10.1016/j.cplett.2013.02.030

162. Cheawchan, S.; Uchida, S.; Sogawa, H.; Koyama, Y.; Takata, T. Langmuir 2016,32, 309315. http://dx. doi.org/10.1021/acs.langmuir.5b03881

163. Peraino, N. J.; Ho, H.-J.; Mondal, M.; Kerrigan, N. J. Tetrahedron Lett. 2014, 55, 42604263.

http://dx. doi.org/10.1016/j.tetlet.2014.05.130

164. Song, L.; Huang, C.; Huang, M., Liu, B. Tetrahedron 2015, 71, 3603-3608. http://dx.doi.org/10.1016/j.tet.2015.01.002

165. Chang, C.-F.; Stefan, E.; Taylor, R. E. Chem. Eur. J. 2015, 10681-10686. http://dx.doi.org/10.1002/chem.201502132

166. Nicolaou, K. C.; C. R. H.; Nilewski, C.; Ioannidou, H. A.; ElMarrouni, A.; Nilewski, L. G.; Beabout, K.; Wang, T. T.; Shamoo, Y. J. Am. Chem. Soc. 2014, 136, 12137-12160. http://dx.doi.org/10.1021/ja506472u

167. Cookson, R.; Pöverlein, C.; Lachs, J.; Barrett, A. G. M. Eur. J. Org. Chem. 2014, 45234535. http://dx.doi.org/10.1002/ejoc.201402205

168. Allen, A. D.; Andraos, J.; Tidwell, T. T.; Vukovic, S. J. Org. Chem. 2014, 79, 679-685. http://dx.doi.org/10.1021/jo402438w

169. Shih, H.-W.; Prescher, J. A. J. Am. Chem. Soc. 2015, 137, 10036-10039. http://dx.doi.org/10.1021/jacs.5b06969

170. Henry, C.; Bolien, D.; Ibanescu, B.; Bloodworth, S.; Harrowven, D. C.; Zhang, X; Craven, A.; Sneddon, H. F.; Whitby, R. J. Eur. J. Org. Chem. 2015, 1491-1499. http://dx.doi.org/10.1002/ejoc.201403603

171. DeGruyter, J. N., Maio, W. A. Org. Lett. 2014, 16, 5196-5199. 
http://dx.doi.org/10.1021/o15025585

172. Radionova, E. S.; Titova, Yu. A.; Isenov, M. L.; Fedorova, O. V.; Rusinov, G. L.;

Charushin, V. N. Chem. Heterocyclic Comp. 2014, 50, 998-1004.

173. Chandra, K.; Naoum, J. N.; Roy, T. K.; Gilon, C.; Gerber, R. B.; Friedler, A. Peptide Sci. 2015, 104, 495-505.

http://dx.doi.org/10.1002/bip.22654

174. Garbarino, G.; Banfi, L.; Riva, R.; Basso, A. J. Org. Chem. 2014, 79, 3615-3622. http://dx. doi.org/10.1021/jo500535f

175. Galvez, J.; Castillo, J.-C.; Quiroga, J.; Rajzmann, M.; Rodriguez, J.; Coquerel, Y. Org.

Lett. 2014, 16, 4126-4129. http://dx. doi.org/10.1021/o15018245

176. Sano, S.; Matsumoto, T.; Yano, T.; Toguchi, M.; Nakao, M. Synlett 2015, 2135-2139. http://dx.doi.org/10.1055/s-0034-1378803

177. Hirano; M.; Okamoto; T.; Komine, N.; Komiya, S. New J. Chem. 2014 5052-5057. http://dx. doi.org/10.1039/C4NJ01001A

178. Mosley, J. D.; Young, J. W.; Duncan, M. A. J. Chem. Phys. 2014, 141, 024306. http://dx.doi.org/10.1063/1.4887074

179. Alvarez, M. A.; García, M. E. ; Menendez, S. ; Ruiz, M. A. Organometallics 2015, 34, 1681-1691. http://dx.doi.org/10.1021/acs.organomet.5b00166

180. Alvarez, M. A.; García, M. E.; García-Vivo, D.; Martínez, M. E.; Ruiz, M. A. Organometallics 2011, 30, 2189-2199. http://dx.doi.org/10. 1021/om1011819

181. Lee, S. Y.; Neufeind, S.; Fu, G. C. J. Am. Chem. Soc. 2014, 136, 8899-8902. http://dx. doi.org/10.1021/ja5044209

\section{Authors' Biographies}

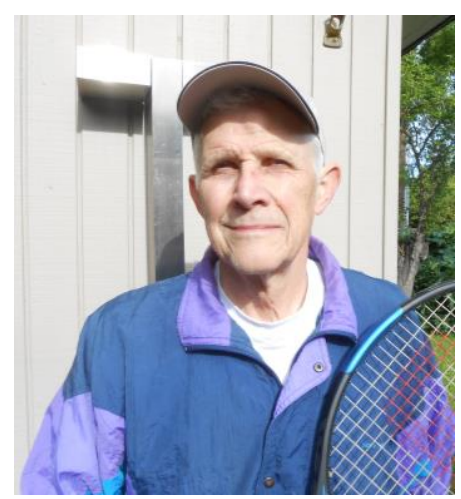

Thomas Tidwell was born in Atlanta, Georgia, on Feb. 20, 1939, received the B. S. in Chemistry from the Georgia Institute of Technology in 1960, and carried out his graduate 
research with Professor Paul D. Bartlett at Harvard University, where he received the Ph. D. degree 1964. He was a postdoctoral fellow at the University of California, San Diego, with Professor Teddy Traylor, and at the University of East Anglia, with Alan Katritzky, and taught at the University of South Carolina, before moving to the University of Toronto in 1972.

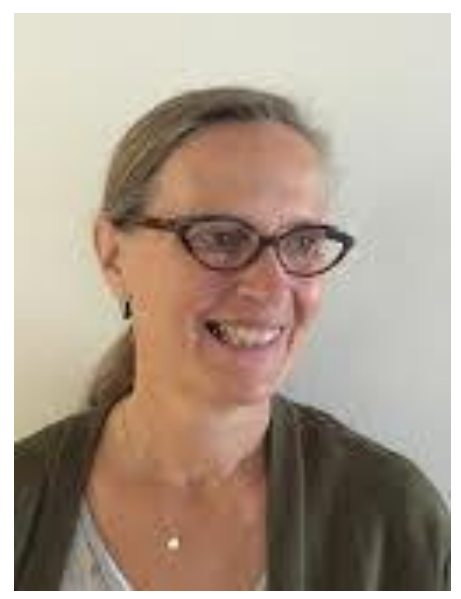

Annette D. Allen was born in Germany, and received a B. Sc Degree at the University of Toronto and an M. Sc. Degree at York University in Downsview, Ontario, and was a Senior Research Fellow in Chemistry at the University of Toronto. 